PRISCILLA MARIA PESSUTTI NASCIMENTO

\title{
Cursos de língua estrangeira para leitura: teoria e prática, com exemplos para o alemão
}

Tese apresentada à Faculdade de Filosofia, Letras e Ciências Humanas para obtenção do título de Mestre em Letras.

Área de Concentração: Língua e Literatura Alemã Orientadora: Prof. Dra. Eliana Gabriela Fischer

São Paulo 


\section{DEDICATÓRIA}

Aos meus pais, à minha irmã e ao meu marido, que sempre me apoiaram e que eu amo acima de tudo. 


\section{AGRADECIMENTOS}

Aos meus pais, Adalberto e Angela, e à minha irmã, Rafaella, pelo amor, pelo incentivo e pelo apoio;

Ao meu marido, Alexandre, por todo o amor e companheirismo, e por sempre me dar forças para continuar;

À Prof. Dra. Eliana Gabriela Fischer, pela confiança em mim e pela orientação;

À Prof. Dra. Cristina Moerbeck Casadei Pietraróia, por participar da minha banca de qualificação e de defesa de mestrado, pelas sugestões valiosas e pelos livros indicados e emprestados;

Ao Prof. Dr. Vojislav Aleksandar Jovanovic, pela participação na minha banca de defesa de mestrado e pelos numerosos conselhos e conversas ao longo dos meus estudos;

Aos meus alunos, que me ensinaram muito mais do que eu a eles. 


\section{RESUMO}

Este trabalho busca estabelecer diretrizes teóricas e práticas para a preparação e execução de cursos de língua estrangeira para leitura, com exemplos retirados de um curso de alemão para leitura de textos de Filosofia e Ciências Sociais, realizado através do Centro de Línguas da Faculdade de Filosofia, Letras e Ciências Humanas da Universidade de São Paulo no ano letivo de 2006. Com este trabalho buscamos orientar professores que trabalham com o desenvolvimento da habilidade de leitura em língua estrangeira e levantar questões relacionadas ao tema.

Palavras-chave: leitura, língua estrangeira, alemão, cursos para leitura, estratégias de leitura 


\begin{abstract}
This dissertation tries to establish theoretical and practical guidelines for the preparation and implementation of foreign language reading courses utilizing examples from a German reading course for Philosophy and Social Sciences that took place in 2006 at the Languages Center (Centro de Línguas) of the Faculty of Philosophy, Languages and Social Sciences at the University of São Paulo (Faculdade de Filosofia, Letras e Ciências Humanas da Universidade de São Paulo). We are attempting to help language teachers who work with the development of foreign language reading skills and to raise questions about this subject.
\end{abstract}

Key words: reading, foreign languages, German, reading courses, reading strategies 


\section{ZUSAMMENFASSUNG}

Diese Arbeit versucht, theoretische und praktische Leitlinien für die Vorbereitung und Durchführung von Lesekursen im Fremdsprachenunterricht aufzustellen, mit Beispielen aus einem Deutschkurs für das Lesen philosophischer und sozialwissenschaftlicher Texte, der im Jahre 2006 im Sprachzentrum (Centro de Línguas) der Fakultät für Philosophie, Sprachwissenschaften und Sozialwissenschaften der Universität São Paulo (Faculdade de Filosofia, Letras e Ciências Humanas da Universidade de São Paulo) durchgeführt wurde. Mit dieser Arbeit wird versucht, Sprachlehrern, die sich mit der Entwicklung des Leseverstehens in Fremdsprachen beschäftigen, eine Orientierung zu geben, und Fragen zu dem Thema aufzuwerfen.

Schlüsselwörter: Lesen, Fremdsprachen, Deutsch, Lesekurse, Lesestrategien 


\section{SUMÁRIO}

1. Introdução 08

2. O que é um curso (de língua) para leitura? 12

3. Concepções fundamentais 16

3.1. Língua 16

3.2. Texto 20

3.3. Leitura 25

3.3.1. Legibilidade 31

3.3.2. Tipos de leitura, compreensão e objetivos 35

3.4. Gramática 40

3.5. Léxico 48

3.6. Estratégias, competências e estilos cognitivos 51

3.7. Motivação e papel do professor 65

3.8. Autonomia 69

4. O trabalho em um curso para leitura 72

4.1. Primeiro contato $\quad 77$

4.2. Grupo 79

4.3. Material e objetivos $\quad 85$

4.4. Fases da aula 91

4.5. Atividades e exercícios 97

4.6. Avaliações 126

5. Especificidades e dificuldades de cursos para leitura 128

5.1. A questão da tradução e do vocabulário 133

5.2. A questão da leitura 148

6. Considerações finais 156

$\begin{array}{ll}\text { 7. Conclusão } & 160\end{array}$

Referências bibliográficas 164 


\section{Introdução}

No início era o texto. Durante muito tempo foi ele a base das aulas de língua estrangeira. Era através dele que o idioma era apresentado, e os alunos tinham como tarefa ler e traduzir. Primeiramente viam-se regras e listas de vocábulos, para depois haver contato com o texto propriamente dito. Saber uma língua era, assim, saber ler e traduzir. E as línguas estudadas em um contexto de aula eram principalmente aquelas ditas mortas, o grego clássico e o latim, que só podiam ser abordadas através de textos e cuja aprendizagem era direcionada justamente para a leitura dos clássicos. ${ }^{1}$

Foi principalmente no final do século XIX e no começo do XX que novas abordagens, metolodogias e métodos começaram a ser pensados e elaborados. Entendemos, segundo LEFFA (1988), abordagem como base teórica, e método como abordagem aplicada. Por isso falaríamos em método gramática e tradução, e não em abordagem, já que ele não dispunha de base teórica prévia. E a palavra método é comumente empregada como sinônimo de material didático, terminologia que procuraremos evitar para não causar confusões. Para nós, o material didático é chamado de livro, apostila ou manual. E metodologia é, a nosso ver, a aplicação prática do método, ou seja, como os passos (método) concebidos de acordo com a base teórica (abordagem) são concretizados nas aulas. Como diz SÁNCHEZ (1993: 8), "utilizar una metodología en la clase de idiomas equivale a elegir un camino determinado para la docencia, frente a otros posibles a que el profesor tiene opción." Ainda segundo SÁNCHEZ (1993: 18), o método, por sua vez, deve "concretar-se en la práctica a través de operacciones, acciones o atividades." A metodologia é, assim, a materialização do método. ${ }^{2}$

Ao refletirmos sobre a questão, pensamos em utilizar o termo "metodologia" por "método", e vice-versa, mas preferimos manter as denominações que costumam aparecer na literatura específica. Entretanto, seria possível pensar em "metodologia" como os passos concebidos de acordo com uma abordagem, e "método" como a aplicação desses passos. Parece ser essa, por exemplo, a visão de ALMEIDA FILHO (2005: 63), pelo menos em alguns momentos:

\footnotetext{
${ }^{1}$ Para um histórico detalhado dos métodos de ensino de línguas, principalmente do ensino voltado à leitura, ver CHAGAS (1979).

${ }^{2}$ SÁNCHEZ (1993: 20) diz que é necessário haver um método de ensino, composto de uma base teórica (que aqui chamamos de abordagem) que traz convicções e crenças que levam à atuação deste ou daquele modo (método), e que se concretiza em sala de aula (metodologia) após a seleção de elementos a serem o objetivo do ensino/aprendizagem.
} 


\begin{abstract}
"Os conceitos de método e metodologia se opõem hoje em dia ao conceito de abordagem (...) - mais amplo e mais abstrato -, indicador, na sua abrangência, de um conjunto potencial de crenças, conceitos, pressupostos e princípios que orientam e explicam (a metodologia) não só as experiências diretas com e na L-alvo (o método) em salas de aulas mas também as outras dimensões do processo complexo (a operação) de ensinar uma língua, a saber, o planejamento curricular e/ou de programas específicos, os materiais de ensino, e a avaliação do próprio processo e dos seus agentes."
\end{abstract}

Independentemente das diferenças de nomenclatura, a atenção dada ao oral nas novas abordagens, metodologias e métodos foi aumentando, principalmente pela maior necessidade de comunicação entre os povos e pelos avanços da tecnologia. As aulas de gramática e tradução continuaram, mas o ensino de línguas foi ganhando outras possibilidades de concretização. E muitas delas com ênfase ou única base no oral, como aconteceu com os métodos direto, situacional e áudio-oral. ${ }^{3}$ Principalmente a partir da metade do século XX, o texto, de papel predominante, passou a um papel secundário, terciário, e muitas vezes praticamente nulo.

Até que se chegou à atual abordagem comunicativa, que norteia a maioria dos cursos de línguas atuais. Essa abordagem baseava-se inicialmente em noções (conceitos como tempo, pessoa, quantidade, localização e sequiência, por exemplo) e funções (o que as pessoas efetivamente fazem com a língua: cumprimentar-se, perguntar e responder sobre determinado assunto, etc.), a partir das quais os métodos e metodologias eram elaborados. ${ }^{4} \mathrm{O}$ aluno passava a ser mais ativo no seu processo de aprendizagem e construção de conhecimento e a se inserir num processo comunicativo simulado de acordo com o real. Voltou-se a dar ênfase às quatro habilidades: compreensão oral, compreensão escrita, produção oral e produção escrita. Assim, o texto foi voltando aos poucos a ter seu papel nas aulas de línguas.

Hoje, no que já é chamada por vários de era do pós-comunicativo, as abordagens, métodos e metodologias tendem a ser mais ecléticos. Aos poucos, o furor comunicativo foi dando lugar a uma reflexão mais madura, em que se percebeu a necessidade de equilíbrio entre o desenvolvimento das quatro habilidades. Não se joga nada fora ou se condena o que veio anteriormente; busca-se aproveitar aquilo que as diversas concepções e aplicações

\footnotetext{
${ }^{3}$ Para um breve histórico das abordagens e métodos de ensinos de línguas, incluindo a abordagem comunicativa, ver LEFFA (1988) e REIS (1998).

${ }^{4}$ Como nos lembra SÁNCHEZ (1993: 41): "Realmente es preciso afirmar que el método comunicativo, tal cual se entiende en la actualidad (...), engloba bastantes más elementos que el inicialmente llamado enfoque nocionalfuncional." O mesmo autor também lembra (1993: 46) que há aqueles que preferem falar em enfoque comunicativo ou então em métodos comunicativos, por entenderem que a aplicação de um enfoque - ou o que aqui chamamos abordagem - possa dar origem a vários métodos.
} 
trouxeram de mais interessante e útil. As novidades não são tomadas radical ou literalmente, como é de praxe acontecer; tenta-se, em geral, buscar um equilíbrio.

Nesse contexto, o texto volta para a sala de aula com um papel importante, e traz consigo a questão da leitura como mais uma habilidade a ser desenvolvida. Há, entretanto, alunos que têm como objetivo principal ou único ler textos em língua estrangeira, geralmente por motivos acadêmicos ou por razões pessoais. Nos chamados cursos comunicativos, que são os mais encontrados hoje em dia nas escolas de idiomas, a oralidade é enfatizada e são simuladas em aula situações próximas ao real, ou seja, que os alunos realmente poderiam viver nos países onde se fala a língua estudada. Tais cursos, porém, não atendem àquele público de futuros leitores, que possui necessidades específicas e que não deseja prioritariamente desenvolver todas as habilidades ligadas ao aprendizado de um idioma. Esse grupo é composto por alunos que não têm necessariamente em vista uma viagem ao país onde se fala o idioma estudado, e que em geral possui pouco ou nenhum contato com falantes nativos. Não obstante, são pessoas que gostariam de se apropriar de tal idioma, muitas vezes de forma rápida, para adquirir conhecimentos específicos, geralmente em uma determinada área do saber. Levando isso em consideração, são desenvolvidos os chamados cursos para leitura, voltados a esses alunos que desejam principalmente ler textos em língua estrangeira. Aqui adotaremos o nome de curso para leitura por acreditarmos que se trata do ensino do idioma através de textos para a finalidade de leitura. Esses cursos são muitas vezes conhecidos como "cursos instrumentais", terminologia que evitaremos aqui e sobre o que discutiremos mais adiante.

Entretanto, devido ao número reduzido de interessados e às necessidades específicas de cada grupo, é muito difícil encontrar material pronto para atender a esses alunos, diferentemente do que ocorre com os livros adotados nos cursos comunicativos. No caso de cursos para leitura, os poucos materiais e textos existentes são em geral relatos de casos e experiências específicas, que acabam sendo o único norte que o professor pode seguir para iniciar seu trabalho. Embora muito interessantes, esses relatos também são por vezes muito restritos $^{5}$, devido ao próprio caráter específico dos grupos com que em geral se trabalha. Desse modo, o professor que se vê frente à preparação de um curso para leitura se sente desamparado, sem suportes teóricos e práticos que possam auxiliá-lo em tal tarefa.

Dentre as inúmeras indagações feitas pelos professores que precisam preparar um curso para leitura, temos: como ensinar uma língua através de textos? Qual o papel da

\footnotetext{
${ }^{5}$ Para um relato de experiência, ver LARANJEIRA e LAUNAY (1977: 25-61). Para um relato mais sucinto e muito interessante sobre alemão para estudantes de Filosofia, ver BORNEBUSCH e FISCHER (1987: 113-122).
} 
gramática? Como trabalhar o texto como texto? Como se dá a leitura? Que tipo de exercícios devem ser feitos? Qual é o papel do oral?

São inúmeros os questionamentos que nos mostraram a necessidade de tentar estabelecer algumas bases teóricas e alguns caminhos para o professor que vai trabalhar com cursos para leitura. Para tanto, acreditamos ser necessário que o professor tenha concepções de língua, de gramática, de léxico, de texto, de leitura, de competências e estratégias, incluindo algumas de suas implicações, a partir das quais possa escolher o material e desenvolver suas atividades. Propomos aqui algumas dessas concepções e tentamos elaborar um guia no qual o professor possa se basear para a elaboração de seu curso. Não desenvolvemos um método fechado, específico, mas apontamos caminhos que, como almejam as abordagens, métodos e metodologias em geral, buscam um ensino/aprendizagem mais eficaz e adequado dentro das circunstâncias em questão. Além disso, buscaremos exemplificar a parte teórica com exemplos retirados das aulas e do material elaborado para um curso de alemão para a leitura de textos voltado a estudantes de Filosofia e Ciências Sociais, ministrado no ano de 2006 na Faculdade de Filosofia, Letras e Ciências Humanas da Universidade de São Paulo através do Centro de Línguas dessa faculdade.

Acreditamos ainda que nosso trabalho pode ser útil tanto em termos teóricos quanto em termos práticos, levando também em consideração a falta de preparo de professores que acabam tendo de ministrar um curso para leitura e que não tiveram a formação adequada na universidade. Parecem ser poucos os cursos de Letras e de Licenciatura que trabalham com essa questão ao longo das aulas - ou, como cremos, mesmo com outros tipos de curso que não os comunicativos. Ao se depararem com a "novidade", os professores muitas vezes nem sabem do que se trata. Mas, afinal, o que é exatamente um curso para leitura? 


\section{O que é um curso (de língua) para leitura?}

Aqui entendemos como o objetivo de um curso (de língua) para leitura (doravante curso para leitura) fornecer uma aprendizagem da língua estrangeira que permita a leitura de textos nessa língua. Assim, a base de apresentação da língua é sempre o texto, o que não impede que outras habilidades sejam minimamente trabalhadas em alguns momentos. A ênfase, entretanto, é na compreensão leitora. Os alunos devem reconhecer estruturas e vocábulos e construir sentidos a partir do que estão lendo, e não (necessariamente) produzir na língua estrangeira. Para tanto, trabalha-se com diversos tipos de compreensão textual, partindo-se em geral dos conhecimentos prévios do aluno, para então serem destacados alguns aspectos da língua.

O curso que aqui chamamos de curso para leitura pode ser de dois tipos, segundo a distinção de PIETRARÓIA (1997: 72): stricto-sensu, ou seja, voltado à leitura de textos técnicos e em que os conhecimentos da área profissional do aluno o auxiliam na compreensão, ou lato-sensu, voltado à leitura de "qualquer tipo de texto por qualquer tipo de aluno". Aqui essa distinção não será fortemente marcada: chamaremos de curso para leitura, assim, o curso onde a língua é ensinada para tal fim, ou seja, a leitura de textos, em geral (mas nem sempre) provenientes de uma determinada área do conhecimento. O curso para a leitura de textos em alemão por nós realizado e que servirá para exemplificação ao longo deste trabalho foi, entretanto, um curso stricto-sensu.

De qualquer modo, independentemente de o grupo ser heterogêneo ou proveniente de um mesmo ramo profissional, é necessário que se faça uma consulta aos alunos para saber quais são seus conhecimentos prévios, seus interesses e objetivos. O plano de trabalho é, assim, feito pelo professor com a colaboração dos alunos. Esse caráter particular do curso para leitura é justamente um dos fatores que dificulta a preparação prévia de materiais, ou seja, é uma das causas da escassez de livros e atividades já prontas nessa área.

Para conhecer o grupo, é interessante que o professor prepare um questionário, que todos os alunos devem responder logo de início. É importante lembrar que cursos para leitura são em sua maioria voltados a um público de jovens adultos e adultos, que, conforme nos lembra VAN PASSEL (1983: 27), em geral freqüentam cursos por livre e espontânea vontade e se propõem a adquirir o máximo de conhecimento possível dentro de um domínio específico num mínimo de tempo. Além disso, o grupo de um curso para leitura deve ter a liberdade de dar sugestões e fazer críticas ao longo das aulas. VAN PASSEL (1983: 30) ainda diz que "são 
as possibilidades do grupo, e só elas, que devem determinar o ritmo do curso", e acrescenta, mais tarde, que "o ritmo do ensino (...) deve ser adaptado ao elemento humano, e não à matéria ensinada" (1983: 31). O professor deverá, assim, ter um plano prévio, com algumas diretrizes básicas e conteúdos mínimos que achar indispensáveis, mas vários aspectos poderão ser mudados no decorrer das aulas dependendo dos desejos, necessidades, sugestões e dificuldades dos alunos.

Segundo RAMOS, CARONI, LAUNAY et al. (1977: 40), quando tratam do curso de francês instrumental:

“(...) não existe metodologia definida a priori; a partir das necessidades dos alunos e do material por eles proposto (...) o professor os levará a utilizar, de modo natural a) as estruturas fundamentais do francês; b) as principais oposições morfo-fonológicas; c) um vocabulário geral neutro, presente em todos os domínios; d) um vocabulário específico do setor lingüístico ou técnico do grupo em questão."

Vale ressaltar que o último item se refere a cursos stricto-sensu apenas, conforme a definição anteriormente mencionada.

PORCHER (1970) apud MONTEIRO (1994: 12), ao falar do francês funcional, diz que ele representa uma tendência "que pretende focalizar domínios específicos de uma língua estrangeira que correspondem às necessidades profissionais ou acadêmicas dos indivíduos (...)." O autor ainda ressalta que "a definição e análise do grupo são indispensáveis (...) para integrar a análise da clientela à própria metodologia."

Já REIS (1990: 23) diz que os princípios metodológicos característicos do que ela chama de Francês Instrumental são: (a) a definição e negociação do conteúdo de acordo com as metas e necessidades dos alunos; (b) acesso a documentos autênticos, escolhidos segundo critérios pedagógicos; (c) estímulo ao envolvimento do aluno-leitor como construtor de sentidos; (d) desenvolvimento da capacidade de leitura em diversos níveis.

Aqui fugiremos da problemática distinção entre "instrumental" e "funcional", geralmente adotada para cursos com ênfases em determinadas habilidades, e principalmente no caso de cursos para leitura. Segundo MONTEIRO (1994: 19), no Brasil o ensino funcional foi chamado de instrumental por ver a língua como um instrumento de acesso à bibliografia de uma área específica do conhecimento e para atender necessidades profissionais; ou seja, era um ensino/aprendizado visto como um meio para alcançar determinados objetivos, a partir das necessidades dos alunos e da situação em que precisariam utilizar a língua. E segundo AUPECLE e ALVAREZ (1977: 9), aquelas são apenas duas dentre várias denominações que 
às vezes são usadas como sinônimas, e outras vezes apresentam nuanças, como, no caso do francês, "français scientifique et technique, français langue de spécialité (...), français langue véhiculaire, français langue outil, français langue documentaire, français de la profession..." 6 Nós aqui não adotaremos um nome para a língua a ser ensinada. Em primeiro lugar, acreditamos que essa língua é sempre a mesma - no nosso caso, o alemão -, mas é feito um recorte (como sempre acontece, qualquer que seja o curso) em função das necessidades e interesses dos alunos. Por isso resolvemos chamar nosso curso de "Curso de alemão para a leitura de textos de Filosofia e Ciências Sociais". Ou seja, o aluno aprende a língua alemã para poder ler textos dessas áreas do conhecimento, o que significa que deverá desenvolver, para alcançar tal fim, conhecimentos lingüísticos, estratégias de leitura e de aprendizagem, dentre outros aspectos de que trataremos ao longo deste trabalho. Assim, poderíamos dizer, dentro do que o uso vem consagrando ${ }^{7}$, que se trata de um curso de alemão para objetivos específicos: no caso, a leitura de textos das áreas em questão.

CORACINI (1989: 19) apud REIS (1990: 23) já lembra, ao tratar do que se costuma chamar de francês instrumental, que ele:

\begin{abstract}
“(...) não mais se restringe à leitura: cursos de compreensão oral com base nos mesmos princípios metodológicos estão acontecendo. Não mais se limita ao terceiro grau: já há experiências com o primeiro e o segundo graus, com suas devidas adequações. Não se restringe mais ao trabalho com textos especializados (...)".
\end{abstract}

Ou seja, os chamados cursos de idiomas para objetivos específicos, "popularmente" conhecidos como instrumentais, podem ser voltados para o desenvolvimento de outras habilidades que não (somente) a compreensão leitora. Aqui, entretanto, trataremos exclusivamente de cursos para leitura.

$\mathrm{O}$ quadro europeu comum de referência para o ensino/aprendizagem de línguas estrangeiras (1998: 13) ${ }^{8}$ traz que os programas de aprendizagem e de certificação em língua estrangeira podem ser globais (envolvendo todas as áreas da competência linguageira ${ }^{9}$ e

\footnotetext{
6 “(...) francês científico e técnico, francês língua de especialidade (...), francês língua veicular, francês línguaferramenta, francês língua documentária, francês da profissão...” (tradução minha).

${ }^{7}$ Os termos já consagrados em alguns dos idiomas são: Alemão para Fins Específicos (ALEFE), Lingua per Scopi Specifici em italiano, Français pour des Objectifs Spécifiques (FSO) em francês, English for Special Purposes $(E S P)$ em inglês. Em inglês há inclusive um nome para uma ramificação desses objetivos específicos, que é o EAP (English for Academic Purposes).

${ }^{8}$ Editado pelo Conselho da Europa (Conseil de L ${ }^{~}$ Europe). Utilizamos a versão francesa desse documento.

9 Em francês, "langagier / langagière", que traduzimos como "linguageiro/a" para não confundirmos com "lingüístico/a". "Linguageiro/a" envolveria diversos aspectos da linguagem, não só o código, ou seja, a parte lingüística em si.
} 
comunicativa), modulares (desenvolvendo as competências do aprendiz em um setor limitado para um objetivo bem determinado), ponderados (dando uma importância particular a este ou aquele aspecto e levando a um "perfil" no qual o saber e o saber-fazer de um mesmo aprendiz estejam em níveis mais ou menos elevados) e parciais (considerando apenas algumas atividades e habilidades, como a recepção, e deixando as outras de lado). Podemos dizer que um curso para leitura se enquadra, assim, no que é chamado de tipo parcial.

Baseando-nos em AUPECLE e ALVAREZ (1977: 19-20), podemos ainda afirmar que um curso como o que aqui propomos dá mais ênfase à recepção e ao escrito, à informação mais do que ao prazer estético, e à compreensão mais do que à tradução. Mas para poder estruturar um curso assim é necessário que o professor tenha diversas concepções teóricas importantes nas quais se basear. E é disso que trataremos agora. 


\section{Concepções fundamentais}

\subsection{Língua}

No presente trabalho consideramos a língua como um conjunto de estruturas fonológicas, lexicais, morfológicas e sintáticas utilizado primordialmente como instrumento de representação e de comunicação ${ }^{10}$ por membros de uma comunidade, e que envolve, entre outros, aspectos socioculturais e pragmáticos. Embora seja uma definição sucinta e que não dá conta de toda a complexidade dos fenômenos lingüísticos, ela será aqui utilizada.

Em cursos para leitura, a língua a ser ensinada é uma língua estrangeira. Entendemos como língua estrangeira uma língua que não é a materna; a língua materna, de acordo com critérios estabelecidos por L. DABENE (1994) é a língua da mãe ou do ambiente parental imediato, a primeira língua adquirida (critério de anterioridade de apropriação), a língua que o aluno conhece melhor (segundo a autora, a anterioridade implicaria num nível superior de competência) e uma língua adquirida de modo natural, ou seja, não em contexto de sala de aula. Não nos aprofundando nessa questão, dificilmente podemos pensar em cursos para leitura como os que aqui discutimos que envolvam a língua materna do aluno; outros cursos podem ser pensados nesse sentido, mas aqui tratamos de cursos de língua estrangeira para leitura. Cursos na língua materna para desenvolver a habilidade de leitura poderiam ser, talvez, chamados de cursos de leitura e teriam de ser elaborados e realizados de outra forma, embora certamente tivessem muitos elementos em comum com os cursos de que aqui tratamos.

No caso dos cursos para leitura voltados à leitura de textos de determinadas áreas do saber, BERRUTO (1987: 154-168) utiliza os termos "línguas especiais" (lingue speciali) e "subcódigos" (sottocodici) como sinônimos quando essas "línguas" realmente possuem um vocabulário próprio ou um léxico específico, que conhecemos em geral como "vocabulário técnico". ${ }^{11}$ VAN PASSEL (1983: 54-56), por sua vez, fala em "língua especializada geral", que forneceria um vocabulário ligado a uma área específica e mais ampla de uma determinada atividade humana, e em "língua especializada particular", que teria uma terminologia técnica

\footnotetext{
${ }^{10}$ É de MOIRAND (1990: 8) que retiramos a definição de língua como "instrumento de representação e comunicação".

${ }^{11}$ Aqui léxico e vocabulário são empregados como sinônimos.
} 
perfeitamente delimitada. Mas, segundo o mesmo autor, seria impossível preparar um curso apenas com as bases tão limitadas de uma língua especializada particular.

Preferimos chamar essa "língua" a ser aprendida/ensinada de subcódigo ou sublíngua $^{12}$, o que indica que ela estaria dentro de uma língua maior, com palavras específicas utilizadas dentro de uma área do saber. Assim, nosso objetivo seria o ensino de uma sublíngua $^{13}$, ou seja, um recorte da língua, que é sempre a mesma. É importante ressaltar, porém, que essas sublínguas não são facilmente definíveis; são formadas por determinadas construções mais freqüentes e pelo vocabulário da área, mas muitas vezes mesclam-se à "língua comum".

Em alemão costuma-se utilizar, para o que aqui entendemos como subcódigo ou sublíngua, o termo Fachsprache, comumente traduzido por "língua especializada". BEIER apud BUHLMANN e FEARNS (1987: 12), define Fachsprache da seguinte forma:

"Fachsprache wird von fachlich kompetenten Schreibern bzw. Sprechern gebraucht, um sich mit anderen (auch angehenden) Fachleuten desselben, mit Vertretern anderer Disziplinen oder Laien mit bestimmten Zielen über fachliche Sachverhalte zu verständigen. Sie umfasst die Gesamtheit der dabei verwendeten sprachlichen Mittel und weist Charakteristika auf allen bisher von der Linguistik aus methodischen Gründen unterschiedenen innersprachlichen Ebenen auf, von denen die lexikalische, morphologische und syntaktische am besten erforscht sind." ${ }^{\text {14 }}$

Já HOFFMANN apud MONTEIRO (1995: 304) define Fachsprache como "die Gesamtheit aller sprachlichen Mittel, die in einem fachlich begrenzbaren Kommunikationsbereich verwendet werden, um die Verständigung der dort tätigen Fachleute zu gewährleisten." 15

Essa sublíngua possui naturalmente graus de especialização. Leitores que desejam ler em língua estrangeira sobre um determinado assunto não se deparam apenas com textos

\footnotetext{
${ }^{12}$ BUGGENHAGEN (1968) fala, por sua vez, em estrato lingüístico: "por estrato lingüístico entendemos a aplicação concreta da linguagem a domínios distintos como a ciência, a conversação cotidiana, a literatura e idiomas profissionais" (segunda página do prefácio, sem numeração). LERAT (1995: 28), por sua vez, não adota o termo "sous-système" (subsistema), preferindo chamar as chamadas línguas de especialidades de "plurisystèmes" (plurisistemas).

${ }^{13}$ É importante ressaltar que não entendemos o prefixo "sub-" nesse caso como algo inferior, e sim como uma (sub)divisão de algo maior, ou seja, a língua em sua totalidade.

14 "A língua especializada é utilizada por falantes e escritores competentes em uma área para se entenderem, no que diz respeito a estados de coisas, com outras pessoas (também iniciantes) da mesma área, com representantes de outras disciplinas ou leigos com determinados objetivos. Ela abrange a totalidade dos meios lingüísticos para isso utilizados e apresenta características em todos os planos intralingüísticos, diferenciados até então pela lingüística por razões metodológicas, dentre os quais o lexical, o morfológico e o sintático são os mais pesquisados até agora." (tradução minha)

15 "A totalidade de todos os meios lingüísticos utilizados em uma área de comunicação delimitável em termos técnicos para garantir a compreensão dos especialistas ali atuantes." (tradução minha)
} 
altamente especializados, mas também com outros, menos técnicos, às vezes até mesmo voltados para leigos, e que trazem um vocabulário diferente daquele que poderia ser considerado como altamente técnico.

Também o chamado vocabulário técnico, dependendo da área do saber, pode ser de difícil definição. HOFFMANN apud MONTEIRO (1995: 306) mostra em um gráfico que as especificidades das Fachsprachen se concentram no campo do léxico, embora a morfologia e a sintaxe também sejam importantes. BUHLMANN e FEARNS (1987: 34), por sua vez, citam alguns critérios para que o termo pertença realmente ao que aqui chamamos de vocabulário técnico: Fachbezogenheit (relação com a área: o termo está relacionado à área), Begrifflichkeit (conceitualidade: o termo denota um conceito), Exaktheit (exatidão: o termo pode ser delimitado em relação a outros, pode ser definido), Eindeutigkeit (especificidade: o termo designa um conceito específico), Eineindeutigkeit (univocidade: o termo designa só um conceito), e Selbstdeutigkeit (autointerpretabilidade: o termo é compreensível mesmo sem contexto). ${ }^{16}$ Entretanto, em diversas áreas, incluindo as áreas do nosso curso - Filosofia e Ciências Sociais -, um mesmo termo pode ter um significado diferente dependendo do autor, do texto ou da época do escrito. E muitas vezes termos usados na "língua comum" são adaptados e adquirem um sentido mais específico dentro de uma determinada disciplina ou para um determinado autor, o que também dificulta a seleção desse vocabulário para o ensino.

No caso de um curso para leitura, voltado a alunos que estão adquirindo a competência lingüística, é importante que ambos os trabalhos sejam feitos: tanto o desenvolvimento da habilidade de leitura quanto a criação de um repertório básico que permita um determinado grau de proficiência. Ou seja, a (sub)língua a ser ensinada envolve tanto estruturas quanto vocabulário, da "língua comum" e "técnico", além do desenvolvimento da capacidade leitora.

Um curso para leitura como o aqui proposto é, na verdade, um curso de língua para leitura, como já expusemos. O aprendizado de uma língua tem, segundo CHAGAS (1979: 117), objetivos instrumentais (ler, escrever, compreender o idioma oral e falar), educativos (“contribuir para a formação da mentalidade, desenvolvendo hábitos de observação e reflexão") e, finalmente, culturais (ministrar ao educando o "conhecimento da civilização estrangeira" e "a capacidade de compreender tradições e ideais de outros povos, inculcandolhe noções da própria unidade do espírito humano"). No nosso caso, os objetivos instrumentais ou práticos envolvem apenas a habilidade de leitura, mas os outros podem e

\footnotetext{
${ }^{16}$ A tradução dos nomes foi feita por mim.

${ }^{17}$ AUPECLE e ALVAREZ (1977: 14) falam de um "vocabulaire général d'orientation scientifique".
} 
devem fazer parte de cursos para leitura e de qualquer outro; além disso, há ainda os objetivos em relação ao desenvolvimento do aluno como aprendiz em direção a uma maior autonomia. Concordamos ainda com CHAGAS (1979: 134) quando ele diz que as línguas podem contribuir para "desenvolver a capacidade de reflexão, a agudeza de julgamento, o espírito de observação, o senso de iniciativa e a apreciação de valores (...)" e que "aprender uma língua é também, sobretudo, conhecer e sentir uma diferente maneira de encarar a vida, ver o mundo de uma nova dimensão que nos amplia os horizontes, nos enriquece a experiência e nos torna mais sábios e mais tolerantes". Acreditamos que esse grande crescimento possa se dar através do contato com qualquer manifestação da linguagem, inclusive - e talvez até principalmente através de textos. 


\subsection{Texto}

Ao longo da história da Lingüística Textual, encontramos diversas definições de texto $^{18}$, que variam segundo os enfoques dados e as correntes de estudos. Porém, o que nos interessa neste momento, independentemente das diferentes nuanças apresentadas pelas diversas definições, é o abandono da idéia de texto como estrutura acabada. Ou seja, passa-se a acreditar que $o$ sentido do texto é construído no curso da interação. ${ }^{19}$

Mas como definir o que é texto? Tomando-o em sentido restrito, adotamos aqui a definição de FÁVERO (1997: 7) de texto como "qualquer passagem falada ou escrita que forma um todo significativo". Para que esse todo seja significativo, o autor deve ter a intenção de construir um texto e de apresentá-lo como tal; o leitor, por sua vez, deve aceitar o que lhe é apresentado como texto e tentar construir a partir dele um sentido. De acordo com o quadro europeu comum de referência para o ensino/aprendizagem de línguas estrangeiras (1998: 15), "texto é toda sequiência discursiva (oral e/ou escrita) inscrita em uma área particular e que dá lugar, como objeto ou objetivo, como produto ou processo, à atividade linguageira ao longo da realização de uma tarefa."20

Assim, acreditamos que seja necessário, para o trabalho em aulas de língua estrangeira, ver o texto como uma estrutura parcialmente acabada que deve exibir determinadas características, mas cujo sentido será construído pelo leitor a partir de seus conhecimentos lingüísticos, textuais e de mundo.

As determinadas características em questão que devem estar presentes no texto, chamadas por BEAUGRANDE e DRESSLER apud FÁVERO (1997: 7) de fatores de textualidade, podem ser critérios adotados pelo professor na escolha de textos "bem formados" e adequados para serem trabalhados em sala de aula. São estes, simplificadamente, os critérios, baseando-nos em KOCH (2004: 35-47):

- Coesão: modo como os elementos da superfície textual se articulam para formar um todo coeso.

\footnotetext{
${ }^{18}$ Para as diferentes concepções de texto, ver KOCH (2004: XII).

${ }^{19}$ Baseando-nos em KOCH (2001: 25).

${ }^{20}$ Tradução minha. No original francês "toute séquence discursive (orale et/ou écrite) inscrite dans un domaine particulier et donnant lieu, comme objet ou comme visée, comme produit ou comme processus, à activité langagière au cours de réalisation d'une tâche."
} 
- Coerência: modo como os elementos subjacentes à chamada superfície textual se combinam para formar um sentido.

- Situacionalidade: relevância do texto para uma determinada situação comunicativa.

- Informatividade: distribuição da informação no texto e como ela é veiculada.

- Intertextualidade: relação do texto com outros textos.

- Intencionalidade: como o texto é articulado para que se chegue às suas intenções.

- Aceitabilidade: aceitação por parte do leitor de uma manifestação lingüística como texto, tentando construir a partir dele um sentido.

Além disso, o professor deve saber selecionar o tipo de texto no que diz respeito ao gênero textual / discursivo, de acordo com os objetivos e interesses dos alunos, e também dos objetivos a que se quer chegar com uma determinada atividade. No caso de um curso para universitários de uma área específica do saber, alguns gêneros indicados seriam índices de livros, biografias de autores importantes, definições de enciclopédias, resenhas de livros, artigos acadêmicos, entre outros.

Já no que diz respeito aos tipos de textos, teríamos:

- Textos informativos, que visam principalmente informar;

- Textos descritivos, que trazem descrições;

- Textos argumentativos, nos quais se expõe uma tese e se argumenta a respeito;

- Textos narrativos, nos quais uma seqüência de eventos é relatada;

- Textos explicativos, em que se encontram sínteses e análises de conceitos;

- Textos instrutivos (que AGATI (1999: 63) chama de "regolativo"), em que são dadas instruções sobre determinados procedimentos;

- Textos preditivos, em que se tenta prever algo que vai acontecer;

- Textos conversacionais, em que se reproduzem diálogos orais;

- Textos retóricos, que, segundo DORRONZONO e PASQUALE (1999), "se encuadran dentro de un conjunto de principios y reglas referentes al arte de hablar o escribir literariamente. Se caracterizan por la presencia de elementos reales tales como figuras de estilo (...), rima, métrica, etc.”

A distinção acima foi feita de acordo com CIAPUSCIO (1994), segundo a qual características histórico-culturais e de conteúdo caracterizam o gênero textual / discursivo 
(uma receita de bolo, um artigo acadêmico, uma notícia de jornal, etc.), enquanto os tipos envolvem critérios mais lingüísticos. É importante lembrar que não existem textos "puros", mas com características predominantes. Outras regras convencionais do que SMITH (1989: 30) chama de estrutura de discurso escrito "incluem a organização em parágrafos, capítulos ou seções, com títulos e outras espécies de cabeçalhos, que os leitores, bem como escritores, devem observar e esperar." O mesmo autor ainda fala em "esquemas de gênero" (SMITH 1989: 59) para caracterizar o que distingue um gênero de texto de outros, como convenções de apresentação, tipografia e estilo. COIRIER et al. (1996: 186), por sua vez, nos lembram que a cada tipo de texto estão associados conteúdos e configurações particulares de marcas (tempos verbais, conectores, marcas de implicação enunciativa), que podem auxiliar em uma identificação rápida pelo leitor do tipo de texto ou da natureza da seqüência textual no caso de um texto heterogêneo.

Por fim, o professor pode se deparar com três tipos de texto no que diz respeito à sua procedência:

- Textos autênticos (que GALISSON apud CICUREL (1991: 19) chamaria de “documentos sociais"): feitos para leitores em geral nativos, inseridos num processo de comunicação real, e não em um contexto de sala de aula. Esses textos são adequados porque motivam bastante os alunos, além de trazerem em geral vocabulário, estruturas e expressões realmente usadas na língua estrangeira. Entretanto, se seu grau de dificuldade for muito alto e não forem propostas atividades adequadas, o aluno poderá sentir-se desmotivado.

- Textos fabricados: feitos para a sala de aula, ou seja, para alunos de língua estrangeira. A vantagem para o professor é que o grau de dificuldade pode ser escolhido, bem como o vocabulário e as estruturas. Pode ser motivador para o aluno se ele entender a maior parte do texto, mas também pode ser menos interessante ou despertar o sentimento de que alunos não conseguem ler textos autênticos.

- Textos adaptados: são os textos autênticos simplificados de acordo com os conhecimentos do grupo. Podem ser menos ou mais motivadores dependendo do grupo e do tema, bem como das atividades propostas.

Além disso, no caso de textos mais especializados, utilizados em cursos stricto-sensu, há a diferença entre textos fundadores e textos didáticos, de acordo com FRIER et al. (1994: 
154-155). ${ }^{21}$ Os textos fundadores seriam textos que têm um papel importante no mundo científico e que contribuíram para a construção do campo conceitual da área, enquanto textos didáticos são textos que explicam textos fundadores de difícil compreensão ou dirigidos a um público leigo ou não tão especializado.

Independentemente do gênero textual ou do tipo de texto escolhido, é necessário lembrar ainda, ou enfatizar, que toda atividade verbal, incluindo textos escritos - que são o foco deste trabalho -, é realizada para alcançar determinados resultados. As atividades verbais, e sociais em geral, envolvem três aspectos, segundo KOCH (2001: 11-15): uma motivação (necessidade ou vontade de transmitir / compreender algo), uma finalidade (para que a mensagem é transmitida / compreendida) e uma realização (como se dá a transmissão / compreensão). Tudo isso ocorre dentro de um processo social e há dependência constante da situação. Assim, os textos devem ser considerados veículos portadores de mensagens que serão (re)construídas pelo leitor durante a leitura, momento em que dependerá da situação social em que estiver imerso.

Essa situação também envolve o contato com o texto propriamente dito. Por isso é importante lembrar que as características da produção escrita são sui generis, diferindo, assim, daquelas que compõem a fala. Segundo LAVEAU (1985: 24-28), no caso dos textos escritos, autor e leitor estão temporal e espacialmente afastados; a pressuposição do autor de seu leitor faz com que haja no texto um certo equilíbrio entre tema e rema, ou seja, entre as informações pressupostamente conhecidas e as consideradas novas; além disso, são utilizados meios tipográficos para auxiliar na "transmissão da mensagem", ou seja, a escrita tem, segundo SMITH (1989: 64), convenções de ortografia, pontuação, formato e dimensão de letras, disposição de letras na página, encadernação, etc. E, conforme nos lembram COIRIER et al. (1996: 191), há recursos como itálicos, negrito e aspas, que são capazes de introduzir modulações (e não gestos ou tom de voz, como na fala). ${ }^{22}$ Podemos ainda dizer que a linguagem do texto é, conforme diferença estabelecida por SMITH (1989: 56), dependente do contexto, ou seja, é invariável onde quer que o leitor esteja; já a fala seria em geral caracterizada por uma linguagem dependente da situação. O leitor, por sua vez, deve conhecer as convenções, ter o mesmo sistema de regras (ou "código") que o autor, ou parte dele - o que é o caso dos alunos de língua estrangeira -, e possuir conhecimentos prévios. Além disso, segundo CAVALCANTI (1989: 35), com base em WIDDOWSON, “a comunicação [através

\footnotetext{
${ }^{21}$ No original, textes fondateurs e textes didactiques.

${ }^{22}$ COIRIER et al. (1996: 192) também falam do papel da segmentação, incluindo a questão do parágrafo, que, embora seja de difícil definição, parece encerrar "unidades" que auxiliam na compreensão.
} 
da leitura] é não-recíproca, indireta e encoberta (...), a negociação só acontecendo nos termos próprios do leitor (por exemplo, ritmo, interesse, propósito, conhecimento prévio)." 23 Assim, segundo essa autora, ao mesmo tempo em que o processo de leitura pressupõe comunicação e interação, o que faz com que leitores diferentes interpretem um texto de forma semelhante, ele também envolve a criatividade, o que traz diferenças de interpretação. Mas é preciso que o leitor saiba reconhecer quais interpretações são realmente autorizadas pelo texto e quais fogem a ele. $\mathrm{O}$ fato de o significado ser construído pelo leitor não quer dizer que possa ser qualquer significado.

É importante que todos esses elementos estejam claros para o professor para que ele possa trabalhar melhor com os textos e ajudar seus alunos a aprender como lê-los.

${ }^{23}$ COIRIER et al. (1996: 191) dizem que, mesmo que o texto se apresente de maneira linear, a leitura pode se fazer na velocidade desejada pelo leitor; ele pode começar a ler quando quiser, parar, voltar, recomeçar, pular partes, ler com atenção ou seletivamente, etc. 


\title{
3.3. Leitura
}

Sabemos que os textos, assim, são produzidos para serem lidos. Mas o que é ler?

Ler é um processo formado de múltiplos processos que ocorrem simultânea e seqüencialmente. É como se, segundo LEFFA (1996a: 17), o escritor fosse o arquiteto e o leitor fosse o construtor. Na planta, que é o texto, o arquiteto deixa algumas informações implícitas, que ele acredita serem conhecidas pelo construtor, e outras explícitas, supostamente novas para o outro. Através da planta, ou texto, o construtor, com seu conhecimento de mundo e as pistas textuais, "constrói" um significado. CLARKE e SILBERSTEIN apud TAGLIEBER (1988: 241) dizem que "o processo de desenvolver uma tarefa de leitura, com suas tentativas e erros, é muitas vezes tão importante quanto o final - a produção das respostas corretas para as perguntas de compreensão.” Assim, a leitura deve ser vista tanto como processo quanto produto.

Concordamos com AGUIAR apud CARDOSO-SILVA (2006: 17) que:

\begin{abstract}
“(...) a leitura é entendida como um processo total de percepção e interpretação dos sinais gráficos e das relações de sentido que se estabelecem entre as palavras, as sentenças, os períodos e os textos. A leitura é, portanto, uma atividade compreensiva através da qual chega-se às idéias, à descoberta dos pormenores, às inferências, à comparação com as idéias de outros autores e com as nossas próprias idéias, às conclusões."
\end{abstract}

Assim, também concordamos com SMITH (1989: 17) que a leitura é "uma atividade construtiva e criativa, tendo quatro características distintivas e fundamentais: é objetiva, seletiva, antecipatória e baseada na compreensão, temas sobre os quais o leitor deve, claramente, exercer o controle."

Mas como aprendemos a ler e como lemos? KLEIMAN (1989: 13-19) expõe um modelo de leitura que aqui sintetizamos: num primeiro momento, o leitor reconhece a letra ou palavra, que vira imagem acústica ou visual e entra na memória de curto prazo (também chamada de imediata, de curto termo ou de trabalho), cuja capacidade é limitada. O material considerado significativo pelo cérebro passa em seguida à memória profunda, de longo prazo ou longo termo, onde está organizado o conhecimento. Além dessas memórias ${ }^{24}$, há uma outra

\footnotetext{
${ }^{24}$ SMITH (1989: 113) prefere usar o termo aspectos da memória, pois não considera apropriado falar em diferentes "espécies" de memória. Ainda segundo ele, a informação visual passa por um armazenamento sensorial, para a memória de curto prazo e, por fim, para a memória de longo prazo (1989: 114). TULVING (1985a, 1985b) apud SMITH (1989: 304) fala, por sua vez, em três sistemas de memória, que chama de
} 
que deve ser aqui considerada, chamada de rasa ou intermediária, que mantém algumas informações num estado de alerta, mais acessíveis do que outras. CHAFE apud FULGÊNCIO e LIBERATO (1996: 70-71) chama esse estado entre a memória de longo e de curto prazo de consciousness. Para exemplificá-la, podemos pensar em duas pessoas conversando sobre lingüística; ambas têm conhecimentos prévios sobre diversas outras áreas, mas no momento daquela conversa os conhecimentos sobre lingüística estão "mais ativados" do que outros. Esses conhecimentos prévios, já anteriormente mencionados e que serão detalhados adiante, estão armazenados na memória em modelos cognitivos globais.

Segundo FÁVERO (1997: 63), modelos cognitivos globais são "blocos de conhecimentos intensamente utilizados no processo de comunicação e representam de forma organizada nosso conhecimento prévio armazenado na memória”. Existem vários tipos de modelos, como frames, esquemas, cenários, planos e scripts. Embora pareça haver uma certa tentativa de classificar eventos e conhecimentos compartilhados dentro de apenas um desses modelos, acreditamos que tal diferenciação muitas vezes não se dá ou que depende dos aspectos considerados em determinado momento. Por exemplo, quando pensamos em uma festa de aniversário infantil, podemos ver tal evento sob diversos ângulos: se imaginarmos um bolo, velinhas, bexigas, chapeuzinhos, docinhos, etc., estaremos ativando um frame. Em termos de ação, que segue uma seqüência temporal ou causal, fixa e pré-determinada, teríamos um esquema se pensássemos na ordem dos acontecimentos nessa festa: as pessoas reúnem-se em torno da mesa, canta-se "parabéns a você", apagam-se as velinhas, corta-se o bolo. Pensando, por outro lado, na festa como um ritual, teríamos a canção "parabéns a você" como parte de um script, realizado em um determinado momento e com palavras fixas. Ou seja, a partir desses exemplos podemos perceber como é difícil classificar os modelos isoladamente, e como um mesmo evento pode ser armazenado dentro de diferentes esquemas. Além disso, é importante lembrar que esses conhecimentos estão relacionados a festas de aniversários no Brasil; em outras culturas, em que há outros tipos de comemorações, esquemas com elementos diferentes seriam ativados. No caso da leitura de textos, é importante apenas sabermos que esses modelos existem e que organizam nosso conhecimento de mundo. Aqui usaremos o termo "esquema", como já estamos fazendo, para tratar dos modelos em geral. ${ }^{25}$

episódico, semântico e de procedimentos. Existem também distinções entre memórias de reconhecimento e de reprodução (SMITH 1989: 307), sobre o que voltaremos a falar.

${ }^{25}$ SMITH (1989: 268) afirma que é esse realmente o termo que vem se consagrando como padrão para denominar os "vários tipos de estruturas mentais abstratas que nos possibilitam extrair um sentido do mundo, e participarmos ativamente dele (...)". 
Sendo modelos compartilhados, os esquemas permitem que várias informações fiquem implícitas no texto, podem ser atualizados e muitas vezes variam de acordo com a cultura, havendo neles variáveis obrigatórias, prováveis e opcionais. ${ }^{26}$

Além disso, GIASSON (1990: 7) lembra que a leitura compreende três elementos que influenciam no todo e que estão intimamente associados: o leitor, com suas estruturas e processos; o texto, portador de forma, conteúdo e intenções; e o contexto: psicológico (interesse, intenção), físico (tempo, ruídos) e social (intervenção do professor e dos colegas, no caso da leitura em sala de aula). Segundo a autora, as estruturas do leitor seriam cognitivas (conhecimentos da língua, que envolvem conhecimentos fonológicos, sintáticos, semânticos e pragmáticos; e de mundo, que envolvem os esquemas e conceitos gerais, que por sua vez possuem variáveis e incluem valores, muitas vezes culturalmente diferentes) e afetivas (atitude geral em relação à leitura e interesses do leitor). Já no processo de leitura em si estariam envolvidos microprocessos, processos de integração, macroprocessos, processos de elaboração e processos metacognitivos, que aqui descreveremos brevemente: ${ }^{27}$

- microprocessos: reconhecimento de palavras, leitura por grupos de palavras, microsseleção;

- processos de integração: utilização de referentes e conectores, inferências a partir de esquemas;

- macroprocessos: identificação de idéias principais, resumo, utilização da estrutura do texto;

- processos de elaboração: predições, imaginário mental, resposta afetiva, relação com conhecimentos, raciocínio;

- processos metacognitivos: identificação da perda de compreensão, reparo da perda de compreensão.

No quadro europeu comum de referência para o ensino/aprendizagem de línguas estrangeiras (1998: 74) consta que, para ler, o leitor deve ser capaz de perceber o texto escrito (aptidões visuais), reconhecer o grafismo (aptidões ortográficas), identificar a mensagem (aptidões lingüísticas), compreender a mensagem (aptidões semânticas) e interpretar a mensagem (aptidões cognitivas). As aptidões (que aqui chamaríamos habilidades, estratégias

\footnotetext{
${ }^{26}$ Essa teoria dos esquemas, ou modelos cognitivos, foi primeiramente exposta por Bartlett em 1932. Para uma boa e rápida introdução ao assunto, ver LEFFA (1996a: 32-44).

${ }^{27}$ Conforme GIASSON (1990: 16).
} 
ou competências, dependendo do caso, como veremos mais tarde) envolvidas nos processos de recepção incluem aptidões perceptivas, memória, aptidões de decodificação, dedução, antecipação, imaginação, "varrida rápida"28 (ou leitura em diagonal) e referências cruzadas.

Há ainda vários modelos em relação à leitura. Segundo CARDOSO-SILVA (2006: 2527), encontramos: (a) o modelo de processamento de dados; (b) o modelo da análise pela síntese; (c) o modelo das múltiplas hipóteses; (d) o modelo construtivista; (e) o modelo reconstrutor. Em síntese, podemos dizer que:

- De acordo com o modelo de processamento de dados, o leitor passa por etapas coordenadas, que iriam automaticamente do estímulo sensorial a uma resposta, o que não parece corresponder totalmente à realidade, embora possa ser uma etapa do processo de leitura.

- De acordo com o modelo da análise pela síntese, parte-se do todo para as unidades ou das unidades para o todo (respectivamente top-down ou bottom-up, especificados mais adiante). Pode-se dizer que isso realmente acontece, mas alternadamente, e que não são os únicos fatores envolvidos na leitura.

- De acordo com o modelo das múltiplas hipóteses, existem vários níveis de leitura, em que ocorrem diversas formulações de hipóteses, ora consciente, ora inconscientemente.

- De acordo com o modelo construtivista, o papel do conhecimento de mundo, ou de uma teoria de mundo, é crucial para o entendimento do texto, e não apenas o texto em si.

- De acordo com o modelo reconstrutor, haveria uma interação do leitor com o próprio autor, cujas intenções poderiam ser desvendadas através de pistas textuais.

Esses modelos, embora separadamente especificados, não parecem ser excludentes e envolvem diversas habilidades, estratégias e competências por parte do leitor, ativadas e desativadas em diversos momentos, de forma menos ou mais consciente. E além dos esquemas compartilhados, utilizados nesse processo, o leitor possui outros conhecimentos importantes que são ativados no momento da leitura: o conhecimento lingüístico ${ }^{29}$ (ou seja, das estruturas lingüísticas, do vocabulário, das combinações possíveis da língua), textual (as

\footnotetext{
${ }^{28}$ Balayage rapide, no original.

${ }^{29}$ Aqui estamos desmembrando o que GIASSON (1990: 7) juntou sob o nome de "estruturas cognitivas e afetivas do leitor".
} 
diferenças entre tipos de textos, gêneros textuais ou superestruturas ${ }^{30}$ ), o conhecimento de mundo ou enciclopédico (que envolve os saberes nas diversas áreas e situações da vida ${ }^{31}$ ) e o sócio-interacional (que envolve as diferentes formas de interação, as intenções do outro, etc.).

No caso de um aluno que está aprendendo uma língua estrangeira, o conhecimento lingüístico é parcial, por isso ele deve valer-se dos outros conhecimentos para compensar as falhas que possui no idioma. É o que WESTHOFF (1987: 41-47) chama de campos de redundância (Redundanzfelder): o primeiro é o conhecimento de combinações de letras; o segundo é o conhecimento de como se formam as orações; o terceiro é o conhecimento de combinações de palavras; o quarto é o conhecimento de estruturas lógicas; e o quinto é o conhecimento de mundo. Como os três primeiros são lingüísticos e os alunos não podem se valer muito deles por ainda estarem aprendendo o idioma, deve-se buscar usar da melhor maneira possível os conhecimentos nos campos quatro e cinco para compensar as falhas nos primeiros, ao mesmo tempo em que nestes devem ser ampliados os conhecimentos.

Nesse sentido, BERTOCCHI apud AGATI (1999: 15) fala em cinco tipos de competências. Para ele, há três competências de primeiro nível: a competência técnica (interpretar aspectos exteriores e físicos do texto; reconhecer e interpretar corretamente seqüências de signos), a competência semântica (interpretar corretamente a relação entre signo gráfico e significado; interpretar o sentido de um trecho), e a competência sintática (interpretar corretamente orações, compreender a relação entre os elementos de uma oração). Já as competências de segundo nível seriam a competência textual (compreender a relação entre partes do texto, o papel dos conectores, as relações anafóricas e catafóricas, etc.) e a competência pragmático-comunicativa (entender o objetivo do texto, dar-lhe um sentido).

Partindo de ambas as classificações, podemos dizer que o leitor precisa de conhecimentos linguiísticos (morfológicos, sintáticos, semânticos), textuais e pragmáticocomunicativos (como se articulam as partes de um texto, como se constrói um significado a partir delas), e de mundo (como se dão determinados eventos e acontecimentos, lógica, relações de causa e conseqüência, etc). É claro que todos esses conhecimentos estão interrelacionados. No caso de um aluno de língua estrangeira, é necessário ampliar os

\footnotetext{
${ }^{30}$ Entendemos aqui como superestrutura a estrutura esquemática e convencional de um texto, variável de acordo com a cultura, formada por microestruturas, que, por sua vez, compreendem basicamente a sintaxe, a semântica ou a pragmática aplicadas a orações isoladas, conforme VAN DIJK (1980). Assim, a superestrutura de um texto é a forma esquemática do conteúdo macroestrutural (que é, grosso modo, o "resumo" do texto). É um conceito em vários pontos semelhante ao gênero discursivo proposto por Bakhtin, e acreditamos que aqui possam ser tratados como sinônimos. Já CICUREL (1991: 13) fala em esquemas formais quando trata de superestruturas e tipos textuais, e de esquemas de conteúdo quando trata do que aqui chamamos de esquemas.

${ }^{31}$ Esse conhecimento, também denominado conhecimento prévio em sentido estrito, SMITH $(1989: 21)$ chama também de informação não-visual.
} 
conhecimentos lingüísticos e se valer dos outros para a compreensão, adaptando-os à realidade do novo idioma e às suas especificidades. 


\subsubsection{Legibilidade}

Assim, sabemos que os textos são produzidos para serem lidos e já temos algumas noções de como se dá a leitura. Mas os textos também devem poder ser lidos. O que torna um texto legível e outro não? O que é legibilidade?

O conceito de legibilidade pode ser definido no momento da leitura. Se não possuímos esquemas mentais, os textos podem se tornar menos legíveis; podemos conhecer as palavras, mas não construir sentidos. É claro que a legibilidade do texto também depende de sua boa formação, e por isso é necessário escolher textos bem estruturados para o trabalho em sala de aula. Entretanto, o que garante que um texto seja realmente legível é, além de sua estrutura, os conhecimentos de que o leitor dispõe. Segundo FULGÊNCIO e LIBERATO (1996: 96), um texto é mais legível "na medida em que permite ao leitor usar maximamente as estratégias de compreensão de que dispõe". Não vemos tudo o que lemos; construímos sentidos também - e principalmente - com base no que inferimos. E quem mais tem para contribuir com os conhecimentos que já possui, mais possibilidades tem de entender. O professor, por sua vez, pode ajudar os alunos a utilizar diversas estratégias e a ativar esquemas cognitivos para que consigam efetivamente ler o texto e desenvolver a metacognição.

A metacognição, segundo LEFFA (1996a: 45-50), é o controle planejado das atividades que levam à compreensão, envolvendo a capacidade de monitorar o próprio entendimento e a habilidade para tomar medidas adequadas quando a compreensão não se dá. A leitura livre, "automática", é um processo cognitivo, mas às vezes detectamos erros, resolvemos parar e retomar um trecho: nesse momento entra em ação esse campo da metacognição da leitura, que é formado por componentes psicogenéticos (ligados ao desenvolvimento natural) e instrucionais (desenvolvidos através da ação específica da educação). É na parte instrucional que o professor tem seu papel; ele pode ajudar o aluno a utilizar a estratégia mais adequada para cada tipo de texto ou de tarefa, e a compreender melhor. Mas como se dá a compreensão?

Segundo BALBONI (1994: 37), a base da compreensão está na chamada "expectancy grammar", ou seja, na capacidade de levantar hipóteses sobre o que deve estar escrito. Essa "gramática da antecipação" opera com base no conhecimento da situação, no conhecimento de mundo e na redundância de informações. Muitos alunos têm dificuldade em entender porque não conseguem construir hipóteses e vêem o texto como algo fechado em si próprio; 
não percebem que devem contribuir para a própria compreensão, que devem interagir com o texto.

Essa construção de hipóteses pode ser feita através de perguntas como "o que espero ler?”, “do que esse texto vai tratar?”, “o que eu sei a respeito do assunto?”, “o que espero encontrar em um texto com essas imagens, com esse título, escrito por esse autor...?". CORNO apud AGATI (1999: 51) diz que "le domande costituiscono l'aspetto più interessante di una teoria della comprensione. Curiosamente si può dire che una persona capisce qualcosa se è in grado di formulare le domande adeguate rispetto alle cose che deve capire." E acrescenta: "Saper fare una domanda è sapere dove cercare la risposta". ${ }^{32}$

A leitura é, assim, um processo interativo, em que o leitor deve ser ativo e em que vários níveis de interação se mesclam e são "compensatórios", sem que haja hierarquia entre eles. Todas essas noções são importantes para o professor para que ajude os alunos a resolverem os problemas quando eles surgirem e a se tornarem bons leitores. E como age um bom leitor?

Segundo pesquisas feitas quase que exclusivamente com leitores lendo textos em língua materna, os bons leitores em geral lêem rapidamente. O movimento de seus olhos é sacádico (em blocos), eles lêem aparentemente sem (ou com pouca) subvocalização ${ }^{33}$, e, quando lêem em voz alta, a velocidade dos olhos é maior do que a da voz. Segundo LEFFA (1996a: 63-64), os leitores bons usam estratégias diferentes para textos diferentes, vêem a leitura como obtenção de significados, parecem depender menos do contexto, valem-se de estratégias de solução de problemas e têm consciência delas. E ainda, segundo WESTHOFF (1987: 47-49), esses leitores têm maior campo de fixação visual e usam estratégias que aumentam a redundância do texto. Além disso, aceitam arriscar-se um pouco, ou seja, aceitam a incerteza para não sobrecarregar a memória de curto prazo. Podem ler rápido e sabem se adaptar às mais diversas situações. Têm, assim, as expectativas certas e as experimentam, tentando prová-las, mas sabem reformular suas hipóteses quando percebem que estão no caminho errado. E, segundo COIRIER et al. (1996: 217) parece que o bom leitor é aquele que consegue se valer de conhecimentos contextuais e de suas competências lingüísticas de maneira suficientemente eficaz (grifo meu).

\footnotetext{
32 “As perguntas constituem o aspecto mais interessante de uma teoria da compreensão. Curiosamente se pode dizer que uma pessoa entende algo se consegue formular as perguntas adequadas a respeito das coisas que deve entender [...]. Saber fazer uma pergunta é saber onde procurar a resposta." (tradução minha).

33 Parece haver uma tendência à subvocalização quando a leitura se torna difícil e há menor possibilidade de previsão, conforme SMITH (1989: 192).
} 
HALL (1989) apud COLOMER e CAMPS (2002: 32) sintetiza em quatro pontos os fundamentos da pesquisa sobre leitura, nos quais nos baseamos e aos quais relacionamos o bom leitor: para a leitura eficiente é necessário que haja processos perceptivos, cognitivos e lingüísticos, que o bom leitor deve saber manejar; como a leitura é um processo interativo e não-linear, o leitor eficiente integra diversos níveis de informação; já que existe limitação do sistema de processamento de informação humano, o bom leitor chega aos processos de alto nível por ter automatizados os processos de baixo nível ${ }^{34}$; e como a leitura é estratégica, o leitor eficiente monitora sua própria compreensão.

O mau leitor, por sua vez, não diferencia estratégias, vê a leitura como mera decodificação, faz mais regressões porque não se vale de seu conhecimento de mundo e não corre riscos. ${ }^{35}$ A leitura nesses casos é tão lenta que o significado global acaba se perdendo.

A velocidade é também um aspecto relevante durante a leitura. Já que realmente ver todas as palavras toma muito tempo, é importante que haja predição do conteúdo. Segundo SILVA (2001: 49-55), a predição acontece porque estamos preocupados com o que vai acontecer num futuro próximo e para eliminarmos a ambigüidade do mundo. Temos muitas possibilidades diante de nós e, se não escolhemos alternativas, precisamos de muito tempo - o que não temos. SMITH (1989: 84) diz que o cérebro não vê tudo, não vê qualquer coisa e não recebe informações dos olhos continuamente, o que leva a crer que a leitura deve ser rápida, seletiva e que depende do que o leitor já sabe. Novamente segundo SILVA (2005b: 137), baseando-se em SMITH, "enquanto a predição constitui o ato de fazer perguntas, a compreensão consiste em ter essas perguntas respondidas." E a autora continua: "A compreensão (...) não é uma medida, mas um estado nulo de incerteza e há somente uma pessoa que pode dizer se o indivíduo compreendeu ou não: o próprio indivíduo.” Assim, a leitura envolveria uma combinação da informação não-visual (que reduz o número de alternativas que o cérebro deve considerar ao longo da leitura) e visual, sendo que o significado seria a informação não-visual mais importante de todas (SMITH 1989: 104).

Mas um bom leitor em língua materna é necessariamente bom em língua estrangeira? Os processos e procedimentos são os mesmos? Ler em língua materna é diferente de ler em língua estrangeira? Quais as semelhanças e quais as diferenças? CAVALCANTI (1989: 1314) apresenta dois caminhos principais de pesquisa de leitura: o primeiro afirma que a leitura em língua materna condiciona a leitura em língua estrangeira - ou seja, leitores não fluentes

\footnotetext{
${ }^{34}$ Os processos de baixo nível, estão, simplificadamente, ligados à decodificação, enquanto os processos de alto nível estão ligados à interpretação.

${ }^{35}$ SMITH (1989: 333) cita alguns autores que trazem pesquisas segundo as quais leitores fracos se valeriam mais do contexto do que bons leitores.
} 
em língua materna não se tornariam bons leitores em língua estrangeira -; e o segundo caminho considera que um leitor em língua estrangeira precisa de uma certa competência lingüística nessa língua para tornar-se proficiente. Para nós, assim como para Cavalcanti, esses caminhos não parecem ser excludentes: acreditamos que é necessária uma certa competência lingüística, que deve ser constantemente ampliada, mas também deve haver o uso de estratégias e de outras competências, relacionadas diretamente ou não, dependendo do caso, à proficiência de leitura em língua materna.

Não se sabe exatamente a influência da leitura em língua materna na leitura em língua estrangeira, quais aspectos realmente diferem nos dois casos, qual o papel do contexto para o desempenho do leitor e quais dificuldades envolvidas nos processos de leitura são determinantes para a falta de entendimento. COIRIER et al. (1996: 212) dizem que o grau de atenção na leitura em língua estrangeira não parece ser o mesmo que em língua materna: de maneira geral, parece que há uma focalização maior da atenção, no caso da língua estrangeira, nos processos de baixo nível (fonéticos e sintáticos; e acrescentamos também os lexicais). Segundos os mesmos autores (1996: 213), todos os leitores em língua estrangeira, bons ou maus, tendem a apelar aos processos de nível inferior.

Mesmo sem muitas conclusões a esse respeito, é importante que o professor perceba e analise as aparentes dificuldades dos alunos para poder estabelecer metas e submetas adequadas. Também é fundamental desenvolver estratégias para a leitura de textos, independentemente do tipo de aula e do tipo de curso ministrado. As estratégias usadas em língua materna nem sempre são automaticamente adaptadas para a leitura em língua estrangeira, e às vezes podem nem mesmo ser adequadas ou aplicáveis em determinados momentos. Algumas, por outro lado, devem ser explicitadas para que o aluno possa fazer uso delas conscientemente e ter um melhor desempenho. Além disso, para diferentes tipos de textos são utilizadas diferentes estratégias, e há também tipos de leitura distintos, que serão detalhados agora. 


\subsubsection{Tipos de leitura, compreensão e objetivos}

Quanto aos procedimentos realizados durante a leitura, podemos inicialmente dividilos, para fins didáticos, em dois: ${ }^{36}$

- bottom-up ou ascendente: processamento baseado em informação visual. Ou seja, parte-se das unidades menores (morfemas, palavras, orações) para se chegar às maiores (ao texto como um todo e sua compreensão e interpretação).

- top-down ou descendente: processamento baseado em informação não-visual. Ou seja, parte-se de aspectos externos, das expectativas e objetivos para a compreensão do texto. Essa compreensão vai do geral para o específico, iniciando-se na mente do leitor, que usa as informações textuais para confirmar suas hipóteses.

A leitura de um texto não acontece de uma só maneira ou somente da outra. Ambos os tipos intercalam-se, ou seja, a leitura é vista como um processo interativo. ${ }^{37}$ Entretanto, podese tentar propor tarefas, em aulas de leitura, que dêem prioridade a um tipo ou ao outro em um determinado momento.

Segundo O’MALLEY e CHAMOT (1990: 36), valer-se apenas do procedimento bottom-up pode levar a três tipos de ineficiências. Primeiramente, o significado da palavra depende do contexto em que ela está, e o processamento se dá mais rápido se o contexto puder estreitar as possibilidades de significado; além disso, parece que indivíduos que fazem previsões a respeito do que vão ler ou à medida que vão lendo tendem a ter maior compreensão, mesmo que, a nosso ver, essas previsões sejam em parte "inconscientes".

Valer-se apenas do procedimento top-down, por outro lado, parece ser limitador, porque se acaba inferindo muito e corre-se o risco, às vezes, de passar mais tempo com as previsões do que com a leitura do texto propriamente dita. Pode-se, com isso, ter a sensação de que leitura é mera adivinhação, e deixar um pouco de lado ou em segundo plano a atividade de leitura em si.

\footnotetext{
${ }^{36}$ PARRY (1997), ao investigar o processo de leitura em inglês como língua estrangeira de dois sujeitos, concluiu que eles tinham estilos diferentes, que chamou de holístico e analítico, e relacionou-os aos tipos topdown e bottom-up, respectivamente, mostrando as diferenças de resultados dos dois leitores.

37 STANOVICH apud MEURER (1988: 264) fala em processo interativo compensatório: "se houver uma deficiência em um nível de processamento, os leitores tentarão compensar por esta deficiência confiando mais acentuadamente em fontes de informação relacionadas a outros níveis". Assim, se não se conhecem muitos vocábulos, por exemplo, são usadas mais estratégias descendentes, como partir do contexto.
} 
Além desses procedimentos de que já falamos, diversos tipos de compreensão podem ser buscados através da leitura de um texto: ${ }^{38}$

- Compreensão de todo o texto, compreensão detalhada, scanning ou compreensão total;

- Compreensão da(s) idéia(s) geral(is), compreensão global, cursórica ou skimming;

- Compreensão de determinadas informações ou compreensão seletiva.

É importante ressaltar que scanning e skimming são por vezes considerados tipos de compreensão (como no quadro acima, em que são sinônimos de compreensão total e de compreensão global, respectivamente), e que em outros casos se trata de procedimentos de leitura, da mesma forma que as leituras ascendente e descendente, já anteriormente mencionadas. Como procedimento de leitura, entende-se skimming como uma "corrida de olhos" pelo texto, em busca do tema ou para ver se algo merece ser lido, enquanto scanning seria uma leitura mais focada, em busca de palavras-chave ou trechos específicos. Esses procedimentos também podem ser considerados estratégias e atividades, como veremos mais adiante.

MINARDI (2000: 10-15) ainda propõe uma divisão para atos de leitura, já que o mesmo texto pode ser lido em situações diferentes e com objetivos distintos:

- Leitura para agir: serve como base para uma ação que será feita em seguida, como é o caso de manuais de instrução ou da lista telefônica;

- Leitura de contato: serve para ter um primeiro contato com o texto e decidir se ele merece ser lido naquele momento;

- Leitura para aprender: serve para que algo realmente seja aprendido, buscando-se informações essenciais e/ou específicas. Aqui incluímos o que pode ser chamado também de leitura de síntese, feita com o objetivo de resumir um texto;

- Leitura reflexiva: serve para fazer refletir, para "dialogar" com o texto. Aqui incluímos também o que pode ser chamado de leitura recreativa, que é feita pelo simples prazer de ler.

\footnotetext{
${ }^{38}$ Diversos autores falam de tipos semelhantes de compreensão, mas utilizam nomes diferentes. Incluímos aqui algumas dessas denominações distintas, construindo um quadro próprio. Os autores em questão são NEUNER (1990) e LAVEAU (1985: 67-72), que cita Löschmann, Buhlmann, Puch, Grellet e Piepho.
} 
SOLÉ (1998) também fala sobre "ler para revisar um escrito próprio", "ler para praticar a leitura em voz alta" e "ler para comunicar um texto para um auditório". Não acrescentamos aqui esses atos de leitura porque "ler para revisar um escrito próprio" é "ler para corrigir", o que não será o objetivo de alunos que querem ler textos autênticos e que não estão desenvolvendo a habilidade de produção; "ler para praticar a leitura em voz alta" tampouco cabe nos objetivos propostos em um curso para leitura e é uma atividade muitas vezes "mecânica", com um mínimo de compreensão; e "ler para comunicar um texto para um auditório" também envolve a habilidade oral - se se tratar de uma comunicação em língua estrangeira -, não desenvolvida num curso somente para leitura; e se for uma comunicação em língua materna, pode entrar no item "leitura para aprender" (e, a partir daí, repassar as informações). Já ROSENBLATT (1978) apud SMITH (1989: 68) resume o que aqui chamamos de atos de leitura em apenas dois tipos: leitura para informação e leitura para experiência. $^{39}$

É importante frisar que os atos de leitura não são necessariamente determinados antes da leitura; o que a leitura do texto possibilitará ao leitor fazer - durante ou depois dela - pode ficar claro apenas no ato da leitura do texto ou após seu término, e não (só) de acordo com os objetivos iniciais do leitor.

Também se costuma encontrar os termos leitura intensiva, ligada ao estudo da língua e ao desenvolvimento de estratégias, ou seja, à situação de sala de aula propriamente dita, e leitura extensiva, que o aluno, independente, realiza pelo prazer de ler ou por outras razões que lhe são próprias. Esses mesmos termos, porém, são muitas vezes usados com outro sentido: segundo MUNHOZ (2001: 13), "extensive reading” seria a forma de leitura que "procura um entendimento global do texto", que "envolve fluência" - é a maneira que lemos quando fazemos uma leitura mais longa; já "intensive reading" seria a forma de leitura feita para retirar do texto uma determinada informação.

É importante observar que aqui não consideramos a prática da leitura em voz alta pelo fato de não termos a produção oral como finalidade em cursos para leitura. Além disso, a leitura em situações reais é quase sempre feita silenciosamente; conforme FOUCAMBERT (1994: 7), "ler é tratar com os olhos uma linguagem feita para os olhos". O mesmo autor diz ainda que "a leitura em voz alta é um comportamento enxertado à leitura, defasado em alguns segundos: é a opção de traduzir oralmente o que já foi compreendido na leitura. Não se lê latim em voz alta; no máximo, oraliza-se." (1994: 8) Oralização, para ele, é a "atividade que

\footnotetext{
${ }^{39}$ Para uma diferença entre "compreensão e informação", que pode levar a caminhos interessantes de pesquisa e de reflexão, ver SMITH (1989), cap.3.
} 
permite constituir uma cadeia oral a partir do escrito." (1994: 8) Embora não possamos dizer, no caso da leitura de textos em línguas vivas, que se trata de uma oralização, acreditamos que, para alunos que só desenvolvem a habilidade de leitura, ocorra um processo semelhante ao que ocorre com aqueles que aprendem línguas como o grego clássico e o latim. Todos, de certo modo, promovem uma certa oralização do texto escrito, e em todos os casos isso parece ser aconselhável, já que faz sentido que ter uma representação fonética, mesmo que um pouco diferente da "oficial", auxilie na fluência e também na memorização / aprendizagem de palavras. De qualquer forma, ler em voz alta não é em geral tido como um objetivo em um curso para leitura. Além disso, ao fazê-lo, o aluno concentra-se principalmente na pronúncia correta das palavras e na entonação, não conseguindo prestar atenção ao conteúdo (o que ocorre inclusive em língua materna). Um exercício possível, porém, seria que o aluno acompanhasse a leitura em voz alta feita pelo professor, para poder associar melhor som e grafia, já que ele de qualquer forma construirá uma representação oral da escrita, menos ou mais próxima à pronúncia ideal do idioma em questão. $\mathrm{O}$ professor também pode pedir aos alunos que leiam trechinhos em voz alta e corrigir erros de pronúncia mais graves, já que essa representação oral acaba sendo inevitável e parece ajudar na aprendizagem e na leitura - e quanto mais correta for a pronúncia, tanto melhor, principalmente se o aluno um dia quiser aprender a falar o idioma; desse modo é possível evitar em parte que erros graves se “cristalizem”. De qualquer forma, esse exercício teria como objetivo ajudar na criação dessa representação fonética, e não seria o objetivo (ou um dos objetivos) de um curso para leitura.

Por fim, há o objetivo didático da leitura, que pode ser o aperfeiçoamento do idioma, o desenvolvimento / a prática de estratégias ou a análise do texto (que, por sua vez, pode se referir ou dar ênfase ao conteúdo ou à parte lingüística). É possível, e até desejável, que haja combinação desses objetivos.

Como um objetivo amplo, desenvolver a habilidade de leitura pode trazer diversas vantagens e ganhos. Concordamos com CHAGAS (1979) que a leitura em si, além de propiciar um exercício mental de construção de significados, que amplia horizontes e a capacidade de raciocínio, é importante para o desenvolvimento de outras habilidades da língua, em geral, e para a expansão do conhecimento. É um dos meios de aprimorar os conhecimentos de uma língua, de aprender mais sobre ela e sobre a cultura do povo que a utiliza. Segundo SMITH (1989: 81): 
"Ler é uma experiência. Ler sobre uma tempestade não é o mesmo que estar em uma tempestade, mas ambos são experiências. Respondemos emocionalmente a ambos, e podemos aprender com ambos."

E, como lembra RIVERS (1975: 210), é mais fácil para o próprio aluno manter a habilidade de leitura sozinho do que as outras habilidades. Parece também que é essa a habilidade mais difícil de ser perdida ao longo do tempo, caso o aluno interrompa seus estudos ou deixe de ter contato com a língua estudada.

Em resumo, para tipos diferentes de textos podem ser propostos diferentes tipos de compreensão em vários momentos e pode-se trabalhar com atos de leitura distintos. O tipo de compreensão diz respeito a como o texto é lido e quais informações são resgatadas durante e após a leitura; já o ato de leitura reflete o objetivo final da leitura, o que é ou será feito com as informações retiradas e os sentidos construídos. Além disso, há os objetivos didáticos da leitura, que no caso de um curso para leitura envolvem em grande parte o aprimoramento da língua. E esse aperfeiçoamento do idioma traz consigo a questão da gramática e do léxico. Por isso voltamos aqui a tratar da questão da língua, pensando agora mais detalhadamente nesses dois aspectos. Iniciemos com a gramática: afinal, o que é gramática? Qual o seu papel em cursos para leitura? 


\subsection{Gramática}

São várias as concepções de gramática que devem ser levadas em conta durante o ensino de uma língua estrangeira. No caso de cursos para leitura, essa questão se apresenta de forma diferenciada. Enquanto nos cursos comunicativos se busca desenvolver as quatro habilidades, em cursos para a leitura a única ênfase que se dá é na compreensão escrita. Sendo assim, a seqüência dos chamados conteúdos gramaticais nos dois casos é totalmente diversa, assim como outros aspectos envolvidos. Mas, afinal, o que é gramática?

Segundo GALISSON e COSTE (1983: 364), "essa palavra correntíssima é delicada quanto à sua definição porque os seus empregos são tão fluidos como múltiplos, sobretudo em metodologia do ensino das línguas". Além dos diversos tipos de gramática, é importante lembrar que também é chamada de "gramática" o livro que contém regras lingüísticas de algum tipo, do que não trataremos aqui.

Inicialmente, dividiremos as gramáticas em dois tipos:

- Gramática normativa: conjunto de regras que devem ser seguidas pelos usuários da língua. Essa gramática está ligada à norma culta, que é a norma de prestígio, geralmente utilizada pela classe dominante, na literatura, nos documentos escritos, em situações formais. BOHN (1988a: 32) nos lembra que "antes do advento do estruturalismo europeu e americano, as gramáticas tinham um cunho mais prescritivo do que descritivo e eram baseadas na língua escrita dos literatos e dos filósofos." Essas gramáticas de que o autor fala trazem exemplos do que aqui agrupamos sob o nome de gramática normativa.

- Gramática internalizada / descritiva: conjunto de regras que são seguidas pelos usuários da língua para formar orações consideradas gramaticais, no sentido chomskiano, e intercompreensíveis entre os falantes de uma determinada comunidade. Assim, a gramática internalizada é o conjunto de regras que os falantes seguem naturalmente, enquanto a gramática descritiva é a tentativa de descrição desses usos e produções a partir da gramática internalizada. Ela, a gramática descritiva, descreve a outra, a gramática internalizada, sem impor juízos de valor. A gramática descritiva também é chamada às vezes de gramática lingüística. Da gramática internalizada, por sua vez, também fazem parte o que se convencionou chamar de gramática ativa, que

\footnotetext{
${ }^{40}$ Essas gramáticas de que fala Bohn são os livros.
} 
envolve os fenômenos que o falante aplica na sua produção lingüística, ou seja, na fala e na escrita, e a gramática passiva, isto é, os fenômenos que são compreensíveis, durante a escuta e a leitura, mas não utilizados pelo falante.

Aqui é importante lembrar que, embora saibamos que o termo "passivo" pode trazer noções equivocadas, já que a compreensão envolve muitos processos ativos por parte do leitor/ouvinte, não entramos aqui no mérito da questão e mencionamos as definições convencionais, consagradas pelo uso. Nesse sentido LITTLEWOOD (1981: 66) nos lembra, ao tratar da habilidade de compreensão oral, que ela exige envolvimento ativo do ouvinte para reconstruir a mensagem, através de fontes lingüísticas e não-lingüísticas. O mesmo vale, a nosso ver, para a habilidade de leitura. Entretanto, em relação às habilidades chamadas "ativas" (fala e escrita), as passivas parecem ser mais simples, conforme nos lembra SÁNCHEZ (1993: 92).

Voltando ao que diz respeito às gramáticas, POSSENTI (1996) agrupa os tipos anteriormente mencionados em três: normativa (conjunto de regras que devem ser seguidas), descritiva (regras que são seguidas), e internalizada (conjunto de regras que o falante domina), mas aqui achamos conveniente uma aproximação entre os dois últimos tipos, como duas faces da mesma moeda, apesar de sabermos que há distinções entre elas. Embora a gramática descritiva não busque necessariamente explicações cognitivas, ela descreve os usos da gramática internalizada, independentemente do que é considerado correto pela gramática normativa. É, para nós, como se fosse o reflexo externo do funcionamento interno. Para os nossos propósitos de ensino de língua estrangeira, acreditamos, assim, que ambas as concepções possam ser aproximadas.

ROULET (1972), por sua vez, divide as gramáticas em gramática tradicional (que se assemelharia ao que aqui chamamos de gramática normativa), gramática estrutural (que envolve diversos modelos e estaria mais próxima ao que aqui denominamos gramática descritiva) e a gramática gerativo-transformacional (desenvolvida inicialmente por Chomsky e apresentada como "síntese das contribuições mais interessantes da gramática tradicional e da estrutural" (ROULET 1972: 43), e que tem elementos que fazem parte do que aqui consideramos como gramática internalizada).

À gramática normativa está extremamente ligada a visão de língua como um conjunto de normas e regras prescritivas, muito comum no ensino de língua materna, enquanto a visão de língua como faculdade de linguagem se relaciona à gramática internalizada e à gramática descritiva. Essa última visão também está ligada a uma concepção construtivista, que por sua 
vez se relaciona à gramática gerativista e à gerativo-transformacional. Essas gramáticas buscariam, segundo ROULET (1969) apud GALLISON e COSTE (1983: 354), elaborar um sistema formal que permitisse "gerar todas as frases gramaticais de uma língua (e só estas) e atribuir a cada uma descrição estrutural". O mesmo autor (1972: 44) diz o seguinte a respeito dessa gramática:

\begin{abstract}
“(...) Chomsky concebe a gramática gerativo-transformacional como um sistema de regras de substituição que, a partir do símbolo inicial Oração e com o auxílio de um léxico, permitem gerar sequiências de símbolos denominadas estruturas profundas, que contêm, em princípio, todas as informações semânticas necessárias à interpretação da frase. Um segundo grupo de regras, ditas de transformação, modifica a ordem dos símbolos dessas cadeias e atribui a cada oração uma estrutura superficial."
\end{abstract}

Já a visão de língua como estrutura ou agrupamento de formas levou, no nível frástico, à gramática da frase, e, no nível do discurso / texto, à chamada gramática textual. Por sua vez, a visão de língua como produção e reconhecimento de significações levou à gramática enunciativa.

SMITH (1989: 51) também lembra que há a gramática semântica, que trabalha com a estrutura profunda no sentido chomskiano, e a gramática transformacional, que serviria como ligação entre a estrutura aparente e seu significado.

Por fim, pensando em termos didáticos, podemos pensar na distinção entre gramática explícita, que é fornecida pelo professor em sala de aula, e a implícita, que é ensinada indiretamente, através de repetição e de exercícios estruturais.

Esses não são os únicos tipos de gramáticas existentes, mas são os mais difundidos, e muitos deles com aplicações pedagógicas. SMITH (1989: 278) lembra-nos, por exemplo, que há ainda a gramática sistêmica (ou funcional), outra alternativa à gramática transformacional, e a gramática cognitiva. ROULET (1972: XV), por sua vez, fala em outras gramáticas e modelos de análise gramatical, como a análise em constituintes imediatos de Wells, a análise distribucional de Harris, a gramática tagnêmica de Pike, a gramática estratificacional de Lamb, a gramática de casos de Fillmore, a gramática do conteúdo de Weisgerber, a sintaxe funcional de Martinet, a gramática de dependências de Tesnière, a gramática de hierarquias de Halliday. ${ }^{41}$ Essas gramáticas, entretanto, parecem estar mais relacionadas à descrição lingüística, e não à aplicação ao ensino/aprendizagem de línguas, ao que algumas delas talvez

\footnotetext{
${ }^{41}$ BOHN (1988: 34) também se refere a uma espécie de "estrutura profunda" de todas as histórias como "gramática das narrativas", e que podemos aproximar ao que chamamos de superestruturas ou gêneros, de que já falamos (nota 30).
} 
nem sejam realmente apropriadas. É importante lembrar, porém, conforme ROULET (1972: 73), que:

\begin{abstract}
“(...) teoria e descrição lingüísticas por si sós ainda não levam ao desenvolvimento de realizações práticas no ensino de línguas, mas constituem uma preliminar indispensável a um desenvolvimento ótimo e eficaz dessas realizações práticas."
\end{abstract}

O mesmo autor ainda lembra que lingüística e ensino de línguas são disciplinas distintas, com objetivos e métodos diferentes. Podemos, assim, dizer que as teorias linguiísticas necessitam de uma mediação para serem aplicadas no âmbito pedagógico, e isso nem sempre é fácil ou mesmo desejável, dependendo do caso.

Após esse breve quadro e as nossas observações, podemos nos focar nas gramáticas que parecem ser mais adequadas ao nosso trabalho. A gramática normativa é sem dúvida importante, principalmente se estamos trabalhando com textos, que em geral obedecem à norma culta. Mas no caso de estrangeiros que estão aprendendo uma segunda língua, o que lhes falta é o sistema dessa língua, os mecanismos de funcionamento interno, e não as regras do "bem dizer". Por isso a gramática normativa ficaria em segundo plano e a idéia principal de gramática que nos nortearia seria, grosso modo, o conjunto de regras de funcionamento da língua.

Nesse sentido nos valemos aqui da definição de GERMAIN e SEGUIN (1998: 32-33) de gramática como o conhecimento interiorizado que um usuário da língua possui. Não queremos dizer com isso que o aluno estrangeiro chegaria às representações internas do falante nativo, mas acreditamos que esse conjunto de regras interiorizadas, essa gramática interna, também pode dizer respeito à interlíngua do aprendiz, à medida que ele vai interiorizando as regras do novo idioma e (re)elaborando hipóteses. ${ }^{42} \mathrm{O}$ ensino da gramática se daria, assim, através da exposição do aluno a uma descrição ou simulação de fatos lingüísticos, promovendo uma tentativa de familiarização que poderia levar a um domínio de determinados aspectos da língua.

GERMAIN e SEGUIN (1998) ainda apresentam três domínios da gramática: uma concepção tradicional que envolveria o conhecimento das regras morfossintáticas; uma concepção ampliada que envolveria também a fonologia e a semântica; e uma concepção

\footnotetext{
${ }^{42}$ O'MALLEY E CHAMOT (1990: 58) definem interlíngua (interlanguage) como "the intermediary form of a second language that often contains elements of both the native and the target language" "“a forma intermediária de uma segunda língua que freqüentemente contém elementos tanto da língua nativa quanto da língua-alvo" tradução minha). Para esse conceito de interlíngua proposto por Krashen e as variáveis de ensino de que ele trata, ver REIS (1998: 23-26) e BESSE e PORQUIER (1984: 216-239).
} 
relativamente ampliada, que incluiria regras de uso (regras morfossintáticas também ligadas a aspectos semânticos) e de emprego (adequação ao contexto lingüístico e à situação de comunicação). Assim, apoiando-nos na terceira definição, acreditamos que a gramática a ser ensinada em um curso para leitura deva conter: elementos estruturais (regras morfológicas, sintáticas...) ligados à gramática internalizada / descritiva e no âmbito da gramática frasal e da gramática textual; elementos da gramática normativa, na medida em que textos obedecem a essas normas; e regras de uso e de emprego, que auxiliariam numa compreensão efetiva do texto, inclusive no que diz respeito a diferenças socioculturais. Como bem lembra JOVANOVIC (1986: 145), há a gramática (ou descrição gramatical / lingüística) em que o professor se apóia e a gramática em si, que será aprendida / ensinada em aula. Assim, o professor pode se apoiar em várias descrições lingüísticas / gramaticais para fundamentar o seu trabalho, mas não são necessariamente essas as gramáticas com as quais ele trabalhará em aula; ou, então, apenas fará recortes delas.

Desse modo, buscar-se-ia, em cursos para leitura, ensinar as regras do sistema lingüístico do novo idioma e sensibilizar o aluno à norma culta e às convenções textuais, desenvolvendo também sua consciência lingüística e metalingüística. ${ }^{43}$

Segundo NAGY (1993: 60), o aluno deve justamente desenvolver essa consciência lingüística e metalingüística, utilizando seus conhecimentos intuitivos e aprimorando também sua capacidade de análise e de reflexão; ou seja, deve-se despertar o aluno à língua/linguagem, que é o que ela chama de "éveil au langage" (language awareness). L. DABENE (1994: 98-104) fala em consciência linguageira (langagière), através da qual o indivíduo seria capaz de considerar o universo da linguagem como existente por si só, distinto da realidade extralingüística, e em consciência lingüística, que seria a faculdade de identificar os elementos que compõem seu repertório verbal ou o das pessoas que o rodeiam como pertencentes a grupos distintos. ${ }^{44}$

Já no que diz respeito à metalinguagem, sabemos que é justamente aí que os alunos em geral têm preconceitos. ${ }^{45}$ Devido à terminologia mal aprendida na primeira língua e à

\footnotetext{
${ }^{43}$ Segundo SCLIAR-CABRAL (1988: 45), “(...) se, por um lado, quanto mais velho for o aprendiz, tanto mais difícil se torna adquirir outros automatismos, o mesmo não se pode dizer do conhecimento metalingǘstico da língua, da incorporação de léxicos mais complexos e referenciados a experiências mais vastas no espaço e no tempo, bem como a adoção de estratégias de aprendizagem diferentes daqueles adotadas pela criança quando aprende a primeira língua num contexto natural espontâneo."

44 A mesma autora, tratando de contextos plurilíngües, fala em consciêntica normativa, consciência etnolingüística e consciência sociolingüística.

${ }^{45}$ Aqui entendemos consciência metalingüística, grosso modo, como a capacidade de refletir sobre formas e estruturas lingüísticas, ou seja, a pensar e falar sobre uma determinada língua, e metalinguagem como os termos adotados para essa discussão / reflexão.
} 
tentativa de imposição de regras da norma culta, os aprendizes desenvolvem muitas vezes “aversão" à gramática em geral. Não a vêem como um instrumento que auxilia com regras de funcionamento, e sim como algo imposto. É, na verdade, a confusão que se faz entre o ensino da gramática de um outro idioma (que deveria ser principalmente a gramática descritiva / internalizada) e o ensino de língua materna (que em geral é a gramática normativa). De qualquer forma, é necessário que se tenha um conhecimento da metalinguagem para as aulas de língua estrangeira.

Mas a metalinguagem não deve ser simplesmente transferida da língua materna para a língua estrangeira; o professor deve retomar com os alunos os conceitos, para ver se eles os têm claros, e transportar aquela realidade para o novo idioma. No caso de nomenclaturas que divergem em ambas as línguas, o professor pode mostrar o equivalente nas duas e adotar a que for mais adequada e com a qual os alunos se sentirem mais à vontade. A metalinguagem deve ser, assim, mais uma ferramenta a ser aplicada, e a consciêntica metalingüística deve ser desenvolvida, já que é um dispositivo cognitivo que permite construir generalizações e auxilia no despertar da consciência lingüística do aluno em qualquer língua, ajudando também na transmissão / aquisição de conhecimentos de forma econômica. E VAN PASSEL (1983: 3637) nos lembra que o adulto capta o fenômeno "língua", assim como qualquer outro de ordem intelectual, de modo lógico e racional; quer saber o que está fazendo, quer saber os porquês. É aí que entra a questão da metalinguagem e da consciência metalingüística.

Também é importante ressaltar que a língua não se resume à gramática; como nos lembra SÁNCHEZ (1993: 11), durante muitos séculos a idéia de língua esteve - e ainda está estreitamente ligada à idéia de gramática. Os alunos devem, assim, perceber que a gramática é parte da língua a ser aprendida, e que não é a mesma gramática utilizada na escola em língua materna. Segundo o mesmo autor (SÁNCHEZ 1993: 16), "si algo queda en la mente de quienes han completado el sistema escolar, este algo es que la lengua es una gramática." E isso deve ser mudado, qualquer que seja o curso ministrado.

No nosso caso específico, em que estamos tratando de cursos para leitura, a manifestação da linguagem com a qual se trabalharia seria o texto escrito. Ou seja, seriam o texto e a frase, alternadamente, a unidade de apresentação da língua a ser aprendida. Para isso temos que pensar em fazer gramática no texto (ou seja, analisar os elementos morfológica e sintaticamente) e gramática do texto (estudar a função dos conectores, analisar as referências anafóricas e catafóricas, etc., fazendo uma análise supraoracional). Assim, é interessante que o professor levante pontos gramaticais e vocabulário a serem examinados e discutidos, mas que também trabalhe com fenômenos textuais. Isso, porém, só deve ser feito após o texto ter 
sido tratado como tal, ou seja, após atividades de compreensão leitora. Além disso, acreditamos que a gramática explícita seja aqui a mais adequada. Desse modo, após as atividades de compreensão do texto, as regras gramaticais, aqui entendidas como regras de funcionamento da língua, são descobertas: as regularidades são apontadas pelo professor e os alunos tentam chegar às regras.

A gramática é vista, assim, como uma ferramenta pedagógica, e não como um fim em si mesma; e, segundo JOVANOVIC (1986: 145), "como um conjunto de regras capaz de permitir ao aluno generalizações, e a reutilização em novos contextos." CHAGAS (1979: 304), por sua vez, concede à gramática uma "função nitidamente sistematizadora". Em um curso para leitura, a gramática deve ser entendida como o conjunto de regras de funcionamento de uma língua e deve ser construída pelos alunos e pelo professor ao longo das aulas. ${ }^{46}$ E é claro que essa gramática não será similar a de um falante nativo: ela dará conta do suficiente para a recepção dos textos escritos, razão pela qual podemos chamá-la de "gramática escrita receptiva e reduzida". Segundo LADMIRAL apud REIS (1979: 76), ao tratar de cursos como o aqui proposto:

"Les étudiants n'ont pas besoin d'apprendre la grammaire de la langue française, mais une grammaire de l'écrit, surtout la grammaire de ce qui présente des difficultés pour un jeune brésilien, lecteur dans sa langue maternelle. Il s'agit d'une grammaire pédagogique, réduite (...), incomplète $(\ldots) " .47$

E acrescentamos: incompleta, mas suficiente para os objetivos dos alunos.

Essa gramática pedagógica ${ }^{48}$ de que fala o autor pode ser entendida como a gramática que é construída pelo aluno, ou seja, o que ele destaca e interioriza da gramática escrita reduzida e receptiva a ele apresentada. Também podemos tomar emprestado o termo gramática de aprendizagem, utilizado por BESSE e PORQUIER (1984), para nos referirmos à gramática construída pelo aluno, enquanto gramática pedagógica poderia ser entendida como aquela que é apresentada pelo professor aos alunos, ou seja, o recorte feito por aquele para fins didáticos.

Já a seqüência gramatical em si deve ser determinada através da análise dos textos. O professor pode se basear nas apresentações tradicionais para iniciar, e ir apresentando os

\footnotetext{
46 DARSKI (1995: 102) chama as análises e sínteses de uma língua realizadas pelo cérebro de "natürliche Grammatik", ou "gramática natural".

47 "Os alunos não precisam aprender a gramática da língua francesa, mas uma gramática do escrito, principalmente a gramática daquilo que apresenta dificuldades para um jovem brasileiro, leitor em sua língua materna. Trata-se de uma gramática pedagógica, reduzida (...), incompleta (...)." (tradução minha)

${ }^{48}$ CHAGAS (1979: 327) fala em "gramática pessoal".
} 
pontos gramaticais / estruturais mais freqüentes na ordem que julgar mais adequada, lembrando-se de que o aluno deve apenas reconhecer estruturas, e não produzi-las - o que permite uma apresentação mais rápida e também diferente daquela que é feita em cursos comunicativos. Afinal, a gramática apresentada / construída é uma gramática escrita, por assim dizer, e para fins de leitura.

Por estarmos trabalhando com textos, essa gramática escrita de que falamos inclui naturalmente a gramática da frase, mas complementada pela gramática textual; ou seja, não apenas as orações devem ser analisadas, mas suas relações entre si. Tudo isso sempre com o objetivo de auxiliar o aluno a compreender e se tornar autônomo. Mas para a compreensão não é necessário apenas saber as estruturas gramaticais de uma língua: é preciso também conhecer pelo menos parte de seu vocabulário. Trataremos agora, assim, da questão lexical. 


\subsection{Léxico}

Ao tratarmos do conceito de língua, abordamos brevemente a questão do vocabulário ou léxico do idioma estudado. Ele é fundamental, bem como as estruturas lingüísticas, pois, segundo CHAGAS (1979: 159):

"O fato de que seja a sentença, e não a palavra, a verdadeira unidade viva da linguagem não impede, antes impõe, que se dê a este assunto [o vocabulário] o relevo que ele está realmente a exigir, porquanto 'a frase é sempre formada de vocábulos que se unem organicamente por um elo comum de idéias' (...)".

Entretanto, o ensino do vocabulário não parece ter bases tão sólidas ou ser tão estudado quanto outros aspectos do ensino de línguas. Como nota PIETRARÓIA (2001: 119):

\footnotetext{
“(...) curiosamente, mas perfeitamente compreensível, à medida que a preocupação das metodologias passou a ser a comunicação - e isso desde os métodos audiovisuais até os métodos interativos -, o vocabulário deixou de ser estudado de modo específico, sem uma posição definida."
}

Segundo a mesma autora, o tratamento lexical passou a ser visto como "um aspecto acessório dentro de ensino de uma língua estrangeira, a tal ponto que alguns estudiosos sentiram a necessidade de pleitear sua volta" (PIETRARÓIA 2001: 120). No que diz respeito a cursos para leitura é ainda mais difícil encontrar estudos nessa área.

Para iniciar, partimos da noção de que o vocabulário de um curso para leitura é formado pelos chamados termos técnicos, quando se trata de uma área específica do saber, e também por um vocabulário mais geral, além das palavras gramaticais. Em relação às palavras que fazem parte do vocabulário técnico, BERRUTO (1987) diz que elas podem ser formadas de três modos: associando-se um significado novo e específico a um significante novo (ou seja, "inventa-se" uma palavra nova); associando-se um significado novo a um significante velho (uma palavra "antiga" passa a ter mais um significado); e associando um significante novo a um significado já existente (geralmente é o caso de empréstimo de outras línguas, em que palavras estrangeiras passam a substituir palavras que já existem na língua com aquele significado). Entretanto, muitas vezes um mesmo termo pode fazer parte da chamada língua comum e também ter uma acepção específica dentro de uma determinada área 
do conhecimento. Em algumas áreas do saber, a delimitação desse léxico pode ser mais problemática do que em outras.

Além disso, entra a questão dos vocábulos mais freqüentes. CHAGAS (1979: 169 em diante) propõe a seleção por fontes (uma palavra seria mais valiosa quanto maior fosse o número de fontes em que aparecesse), pelo significado, por dificuldades, por idades ou profissões (do grupo com que se trabalha), por formas de inflexão (estabelecendo as diversas flexões dos nomes como unidades autônomas, assim como as formas conjugadas dos verbos e outras modificações) $)^{49}$, e por expressões idiomáticas. O mesmo autor, porém, reconhece que parece existir um "vocabulário geral, básico, que é sensivelmente idêntico" a qualquer que seja a profissão (no nosso caso, a área de atuação / estudo dos alunos), que poderia ser um guia para o ensino, e ainda afirma que "o melhor critério para a seleção de vocabulário ainda é a sua freqüência de uso (...)".

A questão que nos colocamos, porém, é como saber quais são as palavras mais comuns e como fazer essas seleções. Existem poucas obras que trazem isso e também são por vezes muito restritas. Para o nosso curso, nos baseamos em glossários e métodos já existentes para tentarmos encontrar um denominador comum. O trabalho nesse sentido, porém, mostrou-se extremamente difícil, e os novos vocábulos acabaram sendo introduzidos à medida que foram aparecendo. Embora pareça ser possível, no caso de cursos stricto-sensu, delimitar o vocabulário técnico de certa forma e elaborar glossários, continua sendo problemático determinar quais palavras da língua comum devem ser ensinadas / aprendidas. Como exemplo, podemos citar um estudo feito por COHEN et al. (1981) apud CAVALCANTI (1989: 142), que utilizaram a técnica de auto-relato com estudantes universitários que falavam inglês como língua estrangeira. Os pesquisadores pediram que os alunos lessem um texto e indicassem os problemas com vocabulários e estruturas por escrito. Resultado: descobriram que eles tinham dificuldades específicas com vocabulário não-técnico, além de problemas com frases nominais longas.

Assim, acreditamos que o professor, durante a elaboração de um curso para leitura, pode se basear em materiais pré-existentes para verificar quais seriam as palavras mais freqüentes na língua ou dentro de uma área específica do conhecimento, bem como consultar glossários de termos técnicos, quando existirem. Além disso, é importante selecionar as

\footnotetext{
49 SMITH (1989: 159) levanta a questão do que é considerado palavra: "gato" e "gatos" seriam palavras diferentes ou formas de uma mesma palavra? E os verbos "caminho" e "caminhei"? E o verbo "caminho" (como em "eu caminho") e o substantivo "caminho", que possuem a mesma forma?
} 
palavras gramaticais da língua e elaborar exercícios específicos para a aprendizagem de vocabulário, bem como praticar com os alunos formas de memorização.

Sobre essa questão voltaremos a falar. Aqui é necessário frisar que tanto a estrutura lingüística quanto as palavras devem ser destacadas durante a aprendizagem. É difícil, por exemplo, dizer a função gramatical de várias palavras fora de contexto, assim como frases consideradas gramaticais podem não fazer nenhum sentido em termos semânticos. Além disso, conforme SMITH (1989: 63), (só) “o conhecimento da gramática e do vocabulário não dá a ninguém domínio da linguagem tanto para sua produção quanto para a compreensão”. Ou seja, são diversos aspectos que devem ser abordados para que o aluno alcance seus propósitos e, com o auxílio do professor, torne-se um leitor autônomo. Ser autônomo significa para nós "saber virar-se", utilizando os conhecimentos construídos e valendo-se de estratégias adequadas. Mas o que são estratégias e quais devem ser desenvolvidas? Como isso se dá? 


\subsection{Estratégias, competências e estilos cognitivos}

No caso do desenvolvimento da habilidade de leitura, as estratégias são importantes para que haja compreensão do texto mesmo com conhecimentos lingüísticos deficientes. E entender todas as palavras isoladamente não significa necessariamente conseguir construir um sentido adequado.

Segundo VAN DIJK e KINTSCH (1983: 65) apud KOCH (2001: 28-29), estratégia é "uma instrução global para cada escolha a ser feita no curso da ação". E baseando-nos nas definições apresentadas por OXFORD (1990: 7-8), podemos entender estratégia como plano ou ação consciente para alcançar um determinado objetivo; assim, as estratégias em geral seriam pensamentos e operações empregadas pelo aprendiz para auxiliar a aquisição, a armazenagem, a recuperação, o uso e a transferência da informação. As estratégias devem possibilitar que se chegue a um determinado objetivo da forma mais eficiente e econômica possível, e os fatores que influenciam em sua escolha são o grau de consciência do leitor, o estágio de aprendizagem em que se encontra, suas expectativas e características pessoais, seu estilo geral de aprendizado, sua motivação, seus objetivos e a exigência das atividades. Uma estratégia só pode ser adotada se houver um problema e a identificação de tal problema. $\mathrm{Ou}$ seja, o leitor se depara com alguns dados e com obstáculos, mas tem um determinado objetivo que precisa alcançar; para tanto, precisa encontrar um caminho para superar as dificuldades que surgiram.

Há diversas discussões em relação à nomenclatura do que até agora chamamos de estratégias. Para A. N. LEONTIEV (1973: 261-263), apud BESSER e PORQUIER (1984: 247), por exemplo, estratégia seria uma escolha de uma classe de decisões, enquanto tática seria a escolha e a execução de uma decisão; já heurísticos (heuristiques) seriam os mecanismos que comandam o grau de redução das buscas pela solução de um problema diante de um grande número de possibilidades.

Nós simplificaremos alguns dos conceitos segundo nosso entendimento e nossos propósitos. Assim, acreditamos que seja interessante distinguir "estratégia" de "atividade". 50 Aqui entendemos "estratégia" como algo que acontece dentro da mente do aprendiz, enquanto "atividade" é o que se pode observar; em outras palavras, a atividade seria a aplicação da estratégia. Muitas vezes esses conceitos parecem sobrepor-se ou coincidir, mas é importante

\footnotetext{
${ }^{50}$ NAIMAN et al. APUD O’MALLEY e CHAMOT(1990: 6) chamam as atividades de "techniques" (técnicas).
} 
que haja, em princípio, tal diferenciação. Além disso, aqui não consideramos a diferenciação entre estratégias diretas e indiretas, de acordo com OXFORD (1990).

Mas o que seriam estratégias de leitura? Embora não sejam exclusivamente para a leitura, podemos pensar em estratégias cognitivas e metacognitivas que também podem ser aplicadas durante a leitura de textos.

As estratégias cognitivas servem para que o aluno compreenda a língua / o texto. Baseando-nos em OXFORD (1990: 18-21), apresentamos um quadro de estratégias cognitivas e atividades correspondentes que podem auxiliar na compreensão escrita: ${ }^{51}$

\begin{tabular}{|c|c|}
\hline $\begin{array}{l}\text { Estratégia } \\
\text { Cognitiva }\end{array}$ & Atividade \\
\hline $\begin{array}{l}\text { Esclarecimento / } \\
\text { verificação }\end{array}$ & $\begin{array}{l}\text { - Pedir / procurar um exemplo de como usar a palavra ou } \\
\text { expressão; } \\
\text { - Consultar uma gramática, dicionário, textos de apoio, } \\
\text { traduções, etc. }\end{array}$ \\
\hline Inferência & $\begin{array}{l}\text { - Tentar descobrir o significado de uma palavra pelo contexto ou } \\
\text { por tentativas. }\end{array}$ \\
\hline Indução & - Tentar depreender uma regra através de exemplos. \\
\hline Transferência & $\begin{array}{l}\text { - Usar informação lingüística conhecida para facilitar a } \\
\text { compreensão / a tarefa. }\end{array}$ \\
\hline $\begin{array}{l}\text { Atenção seletiva / } \\
\text { dirigida; } \text { scanning }\end{array}$ & $\begin{array}{l}\text { - Atenção seletiva para aspectos específicos de uma tarefa, como } \\
\text { buscar palavras-chave; scanning. }\end{array}$ \\
\hline Skimming & $\begin{array}{l}\text { - Skimming: correr os olhos pelo texto para captar a idéia global, } \\
\text { ver do que se trata, se é um texto interessante para ler. }\end{array}$ \\
\hline Tradução & - Traduzir para compreender. \\
\hline Contextualização & $\begin{array}{l}\text { - Tentar compreender através da situação / de elementos não- } \\
\text { lingüísticos. }\end{array}$ \\
\hline Dedução & - Partir da regra para entender usos e exemplos. \\
\hline Análise & - Tentar compreender analisando a estrutura lingüística. \\
\hline Comparação & $\begin{array}{l}\text { - Tentar compreender comparando com outras estruturas ou } \\
\text { outros idiomas. }\end{array}$ \\
\hline $\begin{array}{l}\text { Utilização de } \\
\text { conhecimento } \\
\text { prévio }\end{array}$ & $\begin{array}{l}\text { - Utilizar conhecimento prévio, como o conhecimento de mundo, } \\
\text { para compreender. }\end{array}$ \\
\hline Síntese & $\begin{array}{l}\text { - Sintetizar ao longo da leitura, mentalmente ou por escrito, para } \\
\text { facilitar a compreensão. }\end{array}$ \\
\hline
\end{tabular}

Quadro 1: Estratégias cognitivas

\footnotetext{
${ }^{51}$ Todas as tabelas foram baseadas em OXFORD (1990) e adaptadas para a questão da leitura.

${ }^{52}$ Chamamos de scanning e skimming tanto a estratégia como a atividade. A estratégia seria a busca pelas palavras ou pela idéia geral, respectivamente; as atividades seriam a corrida de olhos pelo papel, para colocar as estratégias em prática. Em relação ao scanning e ao skimming, que também podem ser procedimentos de leitura, ver o item 3.3.2.
} 
Em relação à estratégia de inferência, com base em WESTHOFF (1997: 98), podemos pensar em algumas perguntas a serem feitas para tentar descobrir o significado de uma palavra desconhecida: que classe de palavra é? Ela se parece com palavras que você já conhece? Pode ser dividida em partes? Você conhece o significado de alguma das partes? Qual sua relação com as palavras vizinhas? Que significado(s) faria(m) sentido nessa oração e de acordo com o que veio antes e o que vem depois no texto? Se for impossível descobrir assim, pode-se usar a estratégia de esclarecimento / verificação e recorrer a alguém ou ao dicionário.

Outra estratégia cognitiva é a formulação de hipóteses, na qual várias das estratégias acima podem ser incluídas como subgrupos. As hipóteses podem ser formuladas de três maneiras (segundo FAERCH e KASPER apud ELLIS (1985: 170-171): (1) usando conhecimento lingüístico prévio; (2) induzindo novas regras dos dados de input ${ }^{53}$; (3) combinando os anteriores. Dessas estratégias, uma que não consta no quadro acima é a simplificação. Simplificações são tentativas de controle da gama de possibilidades que se tenta "construir" em uma determinada fase, restringindo as hipóteses àquelas que são fáceis de formar e que vão facilitar a comunicação e/ou compreensão. A simplificação fica evidente em várias estratégias: transferência interlingüística (o uso da língua materna para formar hipóteses na língua estrangeira) e (hiper)generalização (o uso de conhecimento existente da língua estrangeira para outras formas novas). Ambas podem ser consideradas manifestações da estratégia maior de usar o conhecimento lingüístico prévio para facilitar o aprendizado / a compreensão, e podem ser verificadas principalmente na produção, mas também podem ser aplicadas durante a leitura de um texto. ${ }^{54}$

KOHONEN (1990) ainda fala em estratégias redutoras (reductive strategies), em que se evitam riscos (tentar falar de um jeito "mais fácil" quando não se sabe ou não se conhece determinada estrutura ou tempo verbal, por exemplo), e de realização (achievement), que são "risk-taking" e que muitas vezes conduzem a erros, que por sua vez podem levar ao aprendizado. Embora o autor dê exemplos dessas estratégias em usos produtivos, acreditamos que também possam ser usadas para a compreensão. Como exemplo, podemos pensar em alunos que tentam "simplificar" trechos do texto que não parecem ser tão importantes, ou

\footnotetext{
53 Aqui entendemos input, ou insumo, como o "material" lingüístico a que o aprendiz é exposto. Segundo KRASHEN apud SILVA (2005a), os aprendizes só podem entender material lingüístico que possua estruturas um pouco além do que já conhecem. Ou seja, para avançarem de um estágio i para i+1, têm de estar expostos a material lingüístico (input ou insumo) que contenha i+1, em que i é já conhecido.

${ }^{54}$ É importante lembrar que a estratégia pode ser escolhida de acordo com preferências individuais, mas também pode estar ligada ao contexto de aprendizagem, a propriedades da própria língua estrangeira e ao estágio de desenvolvimento do aprendiz, além da tarefa proposta e do tipo de texto, no caso da leitura.
} 
então que se arriscam na interpretação de certas passagens. Essas estratégias são o que aqui já chamamos de simplificação e de formulação de hipóteses.

Assim, vemos que as várias estratégias podem ter vários nomes, às vezes se confundem ou podem ser consideradas subestratégias de outras em determinados momentos. Além disso, consideramos as chamadas estratégias de seleção e predição, citadas por GOODMAN apud CARDOSO-SILVA (2006: 28-29), como parte das nossas estratégias de atenção seletiva/dirigida, e de contextualização e utilização de conhecimento prévio, respectivamente. $\mathrm{O}$ que ele chama de estratégia de inferência também é encontrado aqui com esse nome, mas inclui para ele a inferência de elementos que não estão explícitos no texto.

As estratégias metacognitivas, por sua vez, estão ligadas à análise do processo de aprendizagem, ao planejamento para aprender, ao monitoramento de compreensão (ou da produção, mas não no caso de cursos para leitura) e à auto-avaliação. Alguns exemplos de estratégias metacognitivas: ${ }^{55}$

\begin{tabular}{|c|cl|}
\hline $\begin{array}{c}\text { Estratégia } \\
\text { metacognitiva }\end{array}$ & \multicolumn{1}{|c|}{ Atividade } \\
\hline $\begin{array}{c}\text { Centralização } \\
\text { do aprendizado / } \\
\text { da tarefa }\end{array}$ & $\bullet$ Prestar atenção ao material ou ao professor; \\
\hline $\begin{array}{c}\text { Planejamento } \\
\text { do aprendizado / }\end{array}$ & $\bullet \quad$ Organizar-se; \\
da tarefa & $\bullet$ Identificar o objetivo de determinada tarefa; \\
\hline Avaliação & $\bullet$ & Avaliar-se; \\
do aprendizado / & $\bullet$ & Monitorar-se: identificar erros, buscar o correto. \\
da tarefa & \\
\hline
\end{tabular}

Quadro 2: Estratégias metacognitivas

Além dessas, há também estratégias de memorização ${ }^{56}$, sociais $^{57}$ e afetivas. ${ }^{58}$ As estratégias de memorização, ou mnemônicas, são utilizadas para que algo seja memorizado,

\footnotetext{
${ }^{55}$ Todas as tabelas foram baseadas em OXFORD (1990).

${ }^{56}$ Embora a memorização possa ser considerada, em um sentido mais amplo, como uma estratégia cognitiva, achamos melhor separar aqui as estratégias mnemônicas por serem bastante específicas e estarem ligadas diretamente ao aprendizado da língua, e não (só) à compreensão textual, como é o caso das estratégias cognitivas por nós apresentadas.

${ }^{57}$ O'MALLEY e CHAMEAU (1990: 197) agrupam as estratégias sociais e as afetivas em "estratégias sociais/ afetivas".

${ }^{58}$ DANSEREAU (1985) apud O’MALLEY E CHAMOT (1990: 100) também diferencia estratégias primárias (primary strategies), que são utilizadas diretamente com os materiais de aprendizagem, e estratégias de apoio
} 
ou seja, para que possa ser "resgatado" da memória quando houver necessidade. No caso de idiomas, são extremamente importantes na aprendizagem de vocábulos novos, por exemplo. Como lembra PIETRARÓIA (1997: 138-139), “um dos primeiros objetivos da aprendizagem da leitura consiste justamente em saber reconhecer palavras (...)”, identificando o estímulo visual e atribuindo significação à palavra identificada. Já as estratégias afetivas estão relacionadas às emoções, à motivação e à postura do aluno em relação à sua aprendizagem. As estratégias sociais, por sua vez, envolvem a interação com outros indivíduos, e são extremamente importantes se levarmos em conta que a língua é um instrumento de comunicação. São, entretanto, mais utilizadas durante a aula ou em contato com outras pessoas, e não com os textos em si, mas devem ser aqui mencionadas.

\begin{tabular}{|c|c|}
\hline $\begin{array}{c}\text { Estratégia } \\
\text { de memorização }\end{array}$ & Atividade \\
\hline Repetição / revisão & $\begin{array}{l}\text { - Repetir palavras, estruturas ou trechos várias vezes; } \\
\text { - Ouvir palavras / trechos várias vezes; } \\
\text { - } \text { Anotar palavras; } \\
\text { - Elaborar listas de palavras; } \\
\text { - Escrever várias vezes uma palavra / copiar orações ou } \\
\text { trechos; } \\
\text { - Reler algo várias vezes; } \\
\text { - }(\text { Re)fazer exercícios. }\end{array}$ \\
\hline $\begin{array}{c}\text { Criação de } \\
\text { associações mentais }\end{array}$ & $\begin{array}{l}\text { - Agrupar palavras semelhantes ou relacionadas a um } \\
\text { mesmo tema ou da mesma classe gramatical; } \\
\text { - Associar palavras que tenham alguma relação entre si } \\
\text { para o aprendiz. }\end{array}$ \\
\hline $\begin{array}{c}\text { Aplicação de } \\
\text { imagens, sons e } \\
\text { cores }^{59}\end{array}$ & $\begin{array}{l}\text { - Desenhar / imaginar figuras; } \\
\text { - Mapa semântico: colocar uma palavra no meio ou no } \\
\text { alto de uma folha e ligá-la a outras com linhas ou } \\
\text { flechas, criando relações temporais e/ou lógicas para o } \\
\text { aprendiz; } \\
\text { - Associar palavras semelhantes foneticamente. }\end{array}$ \\
\hline Emprego de ação & - Utilizar gestos / mímica. \\
\hline
\end{tabular}

Quadro 3: Estratégias de memorização

(support strategies), que auxiliam no estabelecimento de uma atitude adequada em relação a aprendizagem e ajudam a lidar com o cansaço, com as dificuldades, etc.

${ }_{59}$ Algumas atividades aí descritas poderiam também ser relacionadas à estratégia maior de "criação de associações mentais". 


\begin{tabular}{|c|ll|}
\hline $\begin{array}{c}\text { Estratégia } \\
\text { afetiva }\end{array}$ & \multicolumn{1}{|c|}{ Atividade } \\
\hline $\begin{array}{c}\text { Diminuição da } \\
\text { ansiedade }\end{array}$ & $\bullet$ & Relaxar, respirar fundo, meditar; \\
\hline Encorajamento & $\bullet$ & Acreditar em si mesmo; \\
& $\bullet$ & Premiar-se. \\
\hline Auto-avaliação & $\bullet$ & Fazer uma lista de suas realizações; mudar objetivos se \\
& necessário; \\
& $\bullet \begin{array}{l}\text { Falar sobre sentimentos e problemas em relação ao } \\
\text { aprendizado. }\end{array}$ \\
\hline
\end{tabular}

\section{Quadro 4: Estratégias afetivas}

\begin{tabular}{|c|c|}
\hline $\begin{array}{l}\text { Estratégia } \\
\text { social }\end{array}$ & Atividade \\
\hline Perguntas e pedidos & $\begin{array}{l}\text { - Pedir esclarecimentos ou verificações (a um } \\
\text { colega, ao professor, a um falante nativo); } \\
\text { - Pedir correção. }\end{array}$ \\
\hline Cooperação & $\begin{array}{l}\text { - Cooperar com os colegas na solução de uma tarefa; } \\
\text { - Cooperar com os outros, negociando o significado. }\end{array}$ \\
\hline Empatia & 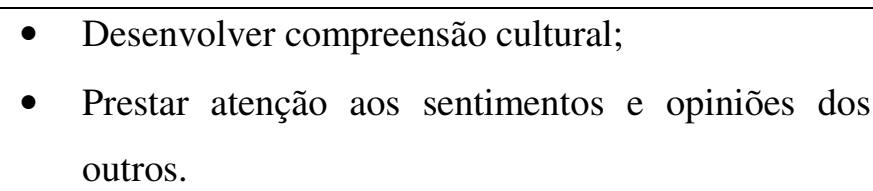 \\
\hline
\end{tabular}

Quadro 5: Estratégias sociais

É importante lembrar que as estratégias já são muitas vezes utilizadas por leitores e aprendizes, de forma menos ou mais consciente, dependendo do caso, mas é interessante explicitá-las e praticá-las em sala de aula para que os alunos, principalmente os que não as utilizam, possam aplicá-las em diversas situações e até mesmo automatizá-las.

As estratégias cognitivas e metacognitivas mencionadas são estratégias de aprendizagem e comunicativas ${ }^{60}$; para nós não há uma grande divisão nesse sentido. Em alguns momentos, algumas dessas estratégias podem ser aplicadas para a comunicação; em outros momentos, com enfoque na aprendizagem. OXFORD (1990: 243) fala de estratégias compensatórias, que para nós passam a ser estratégias utilizadas para compensar falhas e falta de conhecimento, e que tanto podem ser usadas em situações de aprendizagem (sendo,

\footnotetext{
${ }^{60}$ É importante lembrar que também entendemos a leitura de um texto como uma atividade comunicativa, ou seja, não nos referimos apenas a diálogos.
} 
portanto, estratégias de aprendizagem) quanto de comunicação (sendo classificadas então como estratégias comunicativas).

No quadro europeu comum de referência para o ensino / aprendizagem de línguas estrangeiras (1998: 19), dá-se como exemplo um aluno que queira traduzir um texto: para tanto, ele pode pesquisar se já existe uma tradução, pedir a um outro aluno para mostrar-lhe o que este fez, recorrer a um dicionário, tentar reconstruir um sentido a partir de algumas palavras ou construções sintáticas que conhece. Aí estão várias estratégias mescladas, mas que fazem parte do rol de estratégias e atividades que um aluno de um curso para leitura pode utilizar. $^{61}$

Em relação a estratégias em geral no desenvolvimento das quatro habilidades, O’MALLEY e CHAMOT (1990: 140) chegaram à conclusão, após um estudo que fizeram com estudantes de russo e de espanhol, de que os melhores alunos utilizavam um maior número de estratégias, e o faziam de tal forma que conseguiam realizar bem as tarefas propostas. Os alunos malsucedidos empregavam menos estratégias ou estratégias inadequadas. Essa também foi a conclusão a que chegamos em nosso estudo de caso realizado como parte do trabalho de conclusão de curso para a disciplina de Metodologia do Ensino do Alemão, cursada na Faculdade de Educação da Universidade de São Paulo no ano letivo de 2002 e ministrada pelo Prof. Dr. Vojislav Aleksander Jovanovic, que teve como título "Estratégias e atividades utilizadas por alunos de língua estrangeira fora da sala de aula". Esse trabalho foi reestruturado e ampliado como trabalho de graduação interdisciplinar do curso de Letras-Tradutor da Universidade Presbiteriana Mackenzie, com o mesmo título, e sob a orientação da Prof. Ms. Maria Thereza Garrelhas Gentil, em 2003.

Nesse estudo, trabalhamos com alunos de cursos básicos de Inglês e de Alemão, todos alunos da pesquisadora, observados por pelo menos um semestre e classificados como “excelentes", "bons" e "regulares", não apenas devido às notas das avaliações convencionais, mas também de acordo com o desempenho durante as aulas. Havia 10 alunos de cada tipo, num total de 30 alunos. Em resumo, das 46 atividades descritas, os alunos excelentes faziam em média 27,1, enquanto os bons faziam 20,7 e os regulares apenas 15,7. Os excelentes também tinham uma maior média de horas de estudo semanal fora da sala de aula (2,4 horas), seguidos pelos bons (2,05 horas) e pelos regulares (1,4 hora). Além disso, 90\% dos alunos excelentes diziam estabelecer objetivos de aprendizagem, o que era feito por $60 \%$ dos bons e por apenas $50 \%$ dos alunos regulares.

\footnotetext{
${ }^{61}$ No mesmo quadro comum europeu (1998: 59) se fala em estratégias de recepção, das quais fazem parte a identificação do contexto e o conhecimento de mundo, e que aqui chamamos de estratégias cognitivas.
} 
Voltando às estratégias especificamente para a leitura, WESTHOFF (1987: 67) propõe, para seu desenvolvimento (principalmente daquelas que aqui chamamos de cognitivas e metacognitivas), deixar inicialmente claro para o aluno que ele não tem que entender todas as palavras do texto; ele deve tentar inferir o significado pelo contexto e pelas palavras já conhecidas e não deve evitar erros, ajustando suas hipóteses ao longo da leitura. Já para a aquisição de conhecimento, o material deve ser autêntico, deve haver muita leitura e os textos devem trazer um bom equilíbrio entre informação nova e já conhecida (insumo compreensível de Krashen). ${ }^{62}$ Além disso, deve ser possível descobrir o novo através das informações já conhecidas, e deve haver ampliação gradual do conhecimento nos primeiros campos de redundância (os campos lingüísticos). Isso tudo está relacionado ao trabalho direto com o texto, de que trataremos mais adiante.

RUBIN (1981) apud DICKINSON (1987: 131) diz que bons aprendizes, durante a leitura, escolhem uma abordagem de leitura para o texto que devem ler e um propósito para isso; vão resumindo à medida que vão lendo; lêem para um entendimento geral mais do que para um entendimento literal; adotam o que ele chama de "fuzzy processing", em que toleram uma idéia vaga até que possam esclarecer o significado; usam o dicionário economicamente; e valem-se de processamento sintático como último recurso. Esse quadro pode dar ao professor uma idéia de que estratégias priorizar, embora o trabalho dependa de inúmeros fatores e o ensino de estratégias não seja tão simples e pontual.

Segundo GIASSON (1990: 29-33), esse ensino de estratégias deve ser um ensino explícito, em que o professor ensina aos alunos como proceder: (1) primeiramente ele define a estratégia e explica sua utilidade; (2) deixa o processo transparente, mostrando o que deve ser feito; (3) interage com os alunos e os guia no domínio da estratégia; (4) favorece a autonomia na utilização da estratégia; (5) assegura a aplicação da estratégia. Ou seja, o professor deve mostrar "o quê", “o porquê", “como", "quando", e também "para quê". Esse seria um dos caminhos para se chegar à autonomia: o professor assume a responsabilidade, passada gradualmente para o aluno, que finalmente a assume.

O desenvolvimento das diversas estratégias e de habilidades específicas (“concretamente" aplicadas nas atividades) levariam, por sua vez, ao desenvolvimento da competência lingüística / comunicativa, em termos amplos, do aluno. Entendemos competência em sentido restrito como a capacidade de mobilizar conhecimentos e habilidades para agir em uma determinada situação. ${ }^{63} \mathrm{Na}$ verdade, um conjunto de competências,

\footnotetext{
${ }^{62}$ Conforme nota 53.

63 É importante ressaltar que aqui não estamos tratando de competência no sentido proposto por Chomsky.
} 
composto por outras competências ${ }^{64}$, estratégias e habilidades levaria ao desenvolvimento de uma competência maior, que, no aprendizado de um idioma, chamamos aqui de lingüística/comunicativa e envolve diversos fatores. Aproximamos "língua" de “comunicação" porque concordamos com SÁNCHEZ (1993: 55), quando ele diz que "la competencia linguiística es la base principal sobre la que se sustenta la competencia comunicativa y aquélla sin esta última se quedaría reducida a un componente neutro que no necesariamente nos llevaría a poder comunicarnos con normalidad o fluidez", e quando ele afirma (1993: 80) que "la comunicación entre seres humanos se desarolla en su mayor parte mediante el sistema lingüístico, si bien es cierto que nos valemos de otros elementos complementarios (...) La competencia comunicativa incluye los elementos lingüísticos, pero no se agota con ellos.” O mesmo autor ainda lembra (1993: 81) que os elementos lingüísticos são potencialmente comunicativos, pois são sempre suscetíveis de serem utilizados na comunicação; entretanto, conforme ressaltam O'MALLEY e CHAMOT (1990: 73), saber sobre uma língua como um sistema gramatical, que envolve regras sintáticas, semânticas e fonológicas não é condição suficiente para saber essa língua e como usá-la.

Baseando-nos em KOHONEN (1990: 28-29), classificamos as competências ou subcompetências que fazem parte do que aqui chamamos de competência lingüística / comunicativa $^{65}$ em: competência organizacional, que se refere ao conhecimento da organização da língua, dividindo-se em competência gramatical / lexical (que está diretamente ligada ao conhecimento de estruturas da língua e seu vocabulário) e competência discursiva (que se refere à capacidade de criar / compreender um texto falado ou escrito em diversos gêneros, o que se relaciona à questão da coesão e da coerência discursiva); e a competência pragmática, que está relacionada ao conhecimento de funções comunicativas e aspectos sociolingüísticos do uso da língua, subdividindo-se em competência sociolingüística (relacionada à aceitabilidade dos enunciados em situações comunicativas, dependendo dos interlocutores, do assunto e da situação) e competência funcional (ligada à capacidade de desempenhar funções lingüísticas na comunicação). O quadro a seguir sintetiza essa divisão: ${ }^{66}$

\footnotetext{
${ }^{64}$ No quadro europeu comum de referência para o ensino/aprendizagem de línguas estrangeiras (1998: 15) falase também de competências gerais, que não são próprias a línguas, mas que são utilizadas para atividades de todos os tipos, incluídas as relacionadas às línguas.

65 CANALE e SWAIN (1980) apud O'MALLEY e CHAMOT (1990: 73) definem o que chamam de competência comunicativa como a capacidade de usar habilidades (skills) gramaticais, sociolingüísticas, discursivas e estratégicas.

${ }^{66}$ CANALE (1981) apud SÁNCHEZ (1993: 56), por sua vez, fala em quatro competências: a gramatical, a sociolíngüística, a discursiva e a estratégica, que formariam a competência comunicativa.
} 


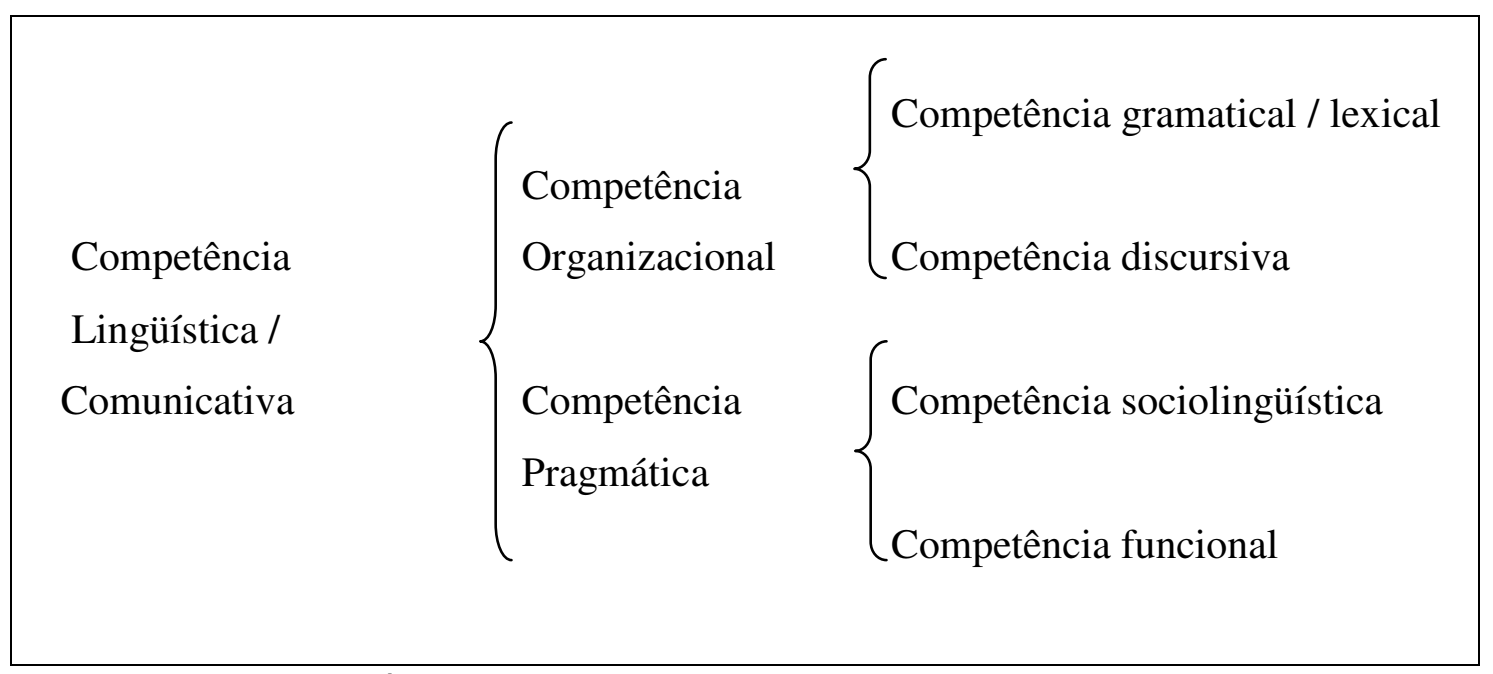

Quadro 6: Competências

Em um quadro também muito interessante apresentado por ALMEIDA FILHO (1993: 9), ele coloca, como elementos da competência comunicativa, a competência linguiística (conhecimentos lingüísticos / código), a competência sociocultural (conhecimentos socioculturais e estéticos), a competência meta (conhecimentos metalingüísticos e metacomunicativos), a competência estratégica (conhecimentos e mecanismos de sobrevivência na interação) e graus de acesso (habilidades).

Podemos pensar ainda em uma competência estratégica, que se aproximaria do conceito geral de competência aqui proposto: saber mobilizar conhecimentos para enfrentar uma situação, como para compensar falta de conhecimento, por exemplo, e também na competência meta de que fala ALMEIDA FILHO (1993).

Como lembra JOVANOVIC (1986: 146), “a língua não é um conhecimento estático. A competência lingüística não é um produto acabado, nem tampouco um conjunto de regras (...) imutáveis no tempo e no espaço." Assim, acreditamos que essas competências devam ser constantemente desenvolvidas, e que o aluno vá, aos poucos, aprendendo a como desenvolvêlas autonomamente.

Subcompetências ou habilidades importantes no caso do desenvolvimento da habilidade de leitura e que devem ser desenvolvidas são o que WESTHOFF (1997: 29-30) chama de "Denk-Handlungen" (“ações de / para o pensamento"), e que aqui adaptamos:

- saber encontrar informações no texto;

- saber reproduzir informações encontradas;

- saber estabelecer critérios em relação àquilo que é importante num texto;

- saber decidir o que é mais importante e resumir; 
- saber estabelecer ligações entre trechos do texto;

- saber procurar palavras no dicionário e decidir qual dos significados é o adequado em relação ao texto que se está lendo.

Além disso, é importante lembrar que, segundo KOHONEN (1990: 26), há dois tipos de conhecimento, de que se fala bastante na literatura específica. O primeiro é o declarativo, que é o conhecimento factual sobre algo; o outro conhecimento é o procedimental (ou procedural), que se refere ao uso lingüístico inconsciente em contextos reais (KOHONEN 1990: 29), implícito, internalizado e contextualizado. ANDERSON (1983, 1985) apud O’MALLEY e CHAMOT (1990: 20) fala naquilo sobre o que sabemos, ou informação "estática" na memória (conhecimento declarativo), e aquilo que sabemos fazer, ou informação "dinâmica" na memória (conhecimento procedimental). Acreditamos que determinados conhecimentos possam fazer parte de um desses tipos apenas, ou, em alguns casos, de ambos. Automatizar o conhecimento declarativo seria transformá-lo em procedimental (caso do aprendizado de uma língua estrangeira em contextos formais), mas voltar ao declarativo pode ajudar a solucionar problemas; além disso, parece que o conhecimento declarativo é adquirido mais rapidamente do que o procedimental. Isso vale tanto para os conhecimentos lingüísticos quanto para os estratégicos.

Assim, após a memorização de regras gramaticais de uma língua, por exemplo, elas começam a fazer parte do conhecimento declarativo do aluno, mas podem ser automatizadas e passar para o conhecimento procedimental (o que inclusive ajudaria na velocidade de leitura e poderia levar à fluência, sem ser o único fator para isso, obviamente). Entretanto, se há um erro de compreensão em um determinado momento da leitura de um texto, tais regras podem ser novamente acessadas para a resolução do problema. O mesmo vale para uma determinada estratégia, praticada inicialmente de forma consciente e depois automatizada.

No que diz respeito novamente às competências, é importante ressaltar que o aprendiz de língua estrangeira já as possui em língua materna, em alguns casos pelo menos em parte, mas deve aprender a adaptá-las em certos casos para o outro idioma, já que muitas vezes a transferência não é automática. Também deve aprender a desenvolvê-las, na medida do possível, quando não tiverem sido bem desenvolvidas na primeira língua. Essa questão é, entretanto, problemática. Segundo COIRIER et al. (1996: 214), os processos de alto nível (como utilização do contexto, referência a estruturas textuais típicas, etc.) parecem a priori transferíveis de uma língua para outra, permitindo em certos casos compensar a insuficiência de processos de baixo nível; entretanto, certas competências utilizadas em língua materna e 
que parecem universais não são necessariamente utilizadas em língua estrangeira, e diversas pesquisas mostram que o papel de tais índices acaba sendo mais importante em língua materna do que em língua estrangeira. Na verdade, parece que é necessário haver um domínio dos processos de baixo nível para que se passe com segurança aos processos de alto nível, sobre o que tornaremos a falar ao tratarmos da questão da tradução e do vocabulário.

Devemos ainda lembrar que, da mesma forma que um aprendiz de língua estrangeira não chegará, em termos de gramática, às representações do falante nativo, isso não acontecerá também em termos de competência. Mas acreditamos que essas competências desenvolvidas podem ser suficientes para os objetivos a que eles se propõem. ${ }^{67}$ Além disso, mesmo entre falantes nativos as competências são variáveis, embora haja intersecções, ou seja, pontos em comum.

Em se tratando de um curso para leitura dirigido a iniciantes, que vão começar a adquirir conhecimentos lingüísticos, podemos ainda falar de habilidades ${ }^{68}$ que devem ser desenvolvidas, como reconhecimento (de sinais distintivos, letras, palavras ou partes de palavras, classes gramaticais, sinais ortográficos, padrões sintáticos, formas de coesão, etc.) e velocidade (para que a leitura se torne fluente). Isso se daria principalmente através de muita prática de leitura.

Além das estratégias a serem utilizadas e das competências a serem desenvolvidas, é necessário ajudar o aluno a trabalhar de acordo com seu estilo cognitivo para obter melhores resultados. Baseando-nos em WILKIN et al. apud LITTLE e SINGLETON (1990: 11), entendemos como estilo cognitivo o modo de funcionamento cognitivo característico dos indivíduos ao realizarem atividades intelectuais, que compreende a tendência natural dos indivíduos na resolução de tarefas intelectuais e as preferências que demonstram e que facilitam seu trabalho. ${ }^{69}$ Segundo LITTLE e SINGLETON (1990: 11), é essencial distinguir entre o estilo cognitivo, que pode ser inconsciente, e a abordagem de uma tarefa, que é mais consciente. A abordagem consciente em geral é determinada por experiências prévias, incluindo o modo como os indivíduos foram ensinados. Se abrimos caminhos para que

\footnotetext{
${ }^{67}$ VAN PASSEL (1984: 34) diz: "Mesmo alguém pouco familiarizado com o fenômeno 'língua' sabe muito bem que não há limites para o domínio da língua materna e que o mesmo ocorre em língua estrangeira."

${ }^{68}$ Das quais fazem parte os "Denk-Handlungen" de Westhoff e para que se dêem os microprocessos e processos de integração, segundo GIASSON (1990), conforme item 3.3.

${ }^{69}$ Em relação à aprendizagem, por exemplo, ENTWISTLE (1981) apud DICKINSON (1987: 21) diz que "holist learners tend to ask questions about broad relations and form hypotheses about generalisations, while serialists ask questions about much narrower relations and form specific hypotheses" ("aprendizes holísticos tendem a fazer perguntas sobre relações amplas e formulam hipóteses sobre generalizações, enquanto serialistas fazem perguntas sobre relações muito mais estreitas e formulam hipóteses específicas" - tradução minha).
} 
diferentes estratégias sejam testadas, os alunos podem, em casos em que isso seja possível, adotar procedimentos que condizem mais com seus estilos cognitivos.

KOHONEN (1990: 25) fala em quatro estilos cognitivos básicos, baseando-se em KOLB (1984): estilo divergente (que enfatiza experiência concreta e observação reflexiva); estilo assimilativo (que enfatiza observação reflexiva e conceitualização abstrata); estilo convergente (que enfatiza conceitualização abstrata e experimentação ativa); e estilo acomodativo (que enfatiza experimentação ativa e experiência concreta). ELLIS e SINCLAIR (1990: 169) falam em um tipo analítico, que tende para a aprendizagem consciente, e um tipo "relaxado", que tende para uma aquisição mais subconsciente, além do tipo misto (mixture). Esses estilos são bem complexos e provavelmente não há apenas um para cada pessoa, embora pareça haver tendências; no entanto, para o ato específico de aprendizagem de uma língua, pode ser que essas tendências sejam mais estáveis. Perceber como isso se dá pode ajudar. Ou seja, refletindo sobre seu próprio processo de aprendizagem e sobre como aprende melhor, o aluno pode perceber como avançar.

Parece que, principalmente no início, materiais e atividades que estimulam a tomada de riscos com base na dependência de contexto são bastante indicados para a autopercepção do aluno e para o desenvolvimento de estratégias; por outro lado, os alunos logo precisam começar a desenvolver um repertório lingüístico e a capacidade de refletir sobre as formas da nova língua independentemente do contexto.

Para melhorar a eficiência na aprendizagem, DICKINSON (1987: 23) sugere uma estratégia de planejamento ativa (saber o que quer fazer), uma estratégia de aprendizagem explícita e uma estratégia afetiva. Bons aprendizes sabem estabelecer objetivos; vêem a língua como um sistema formal com regras e relações entre forma e significado; procuram desenvolver técnicas de prática e memorização e checam seus resultados; sabem que inicialmente serão o que ela chama de "linguistic infant"; e têm atitudes positivas diante das dificuldades e dos choques culturais. Já os fatores afetivos (1987: 25) envolvem choque lingüístico, choque cultural, estresse lingüístico e ansiedade. Deve-se tomar cuidado com a a inibição, que pode ser causada pela classe e até pelo professor - daí a importância de uma boa atmosfera na sala de aula. A auto-avaliação (1987: 26), por sua vez, seria uma forma de criar maior empatia entre alunos e professores, por exemplo. Além disso, para essa autora (1987: 85) a auto-instrução é fundamental, pois ensina a analisar necessidades, a desenvolver técnicas para uso de textos autênticos, a como encontrar materiais e a como usá-los, e ajuda em questões como a organização do tempo. 
Além disso, em relação às estratégias em geral, existe uma discussão a respeito de como deve ser realizado seu ensino: se juntamente com o ensino lingüístico ou se separadamente, isto é, em momentos diferentes ${ }^{70}$, conforme O’MALLEY e CHAMOT (1990: 152 em diante). Acreditamos que ambos os trabalhos possam ser feitos, dependendo do grupo, do texto com que se trabalha e dos diversos fatores envolvidos. O problema é que os professores ainda estão "crus" no que diz respeito ao ensino de estratégias; não há quase treinamentos a respeito, e os materiais didáticos que existem em geral não trazem muitas instruções nesse sentido.

Por isso apresentamos aqui, segundo PARIS (1988a) apud O’MALLEY e CHAMOT (1990: 161) algumas técnicas instrucionais que podem ser utilizadas pelo professor em sala de aula: modeling (modelagem: o professor demonstra ao aluno como usar a estratégia, expondo os objetivos e processos mentais envolvidos); direct explanation (explicação direta: o professor explica a estratégia e seus benefícios), scaffolding instruction ("instrução de andaime": o professor dá um apoio temporário à medida que os alunos vão experimentando as estratégias) e cooperative learning (aprendizagem cooperativa: equipes heterogêneas trabalham juntos no cumprimento de uma tarefa). É uma proposta semelhante à de GIASSON (1990), já apresentada anteriormente.

O trabalho com estratégias e o desenvolvimento das competências, bem como a conscientização do estilo cognitivo, são extremamente úteis e podem contribuir não só para o processo de aprendizagem do aluno, mas também para um aspecto relevante na aprendizagem de qualquer coisa, que é a motivação. À medida que os alunos sentem que vão progredindo realmente, a motivação aumenta. É desse fator importantíssimo e muitas vezes esquecido que trataremos no próximo item.

\footnotetext{
${ }^{70}$ Fala-se em "direct instruction" e "embedded instruction".
} 


\subsection{Motivação e papel do professor}

Segundo BALBONI (1994: 75-78) não existe aquisição sem motivação. As fontes primárias da motivação humana seriam o prazer, a necessidade e o dever. Mas como o dever não parece ser um estímulo positivo, já que muitos reagem negativamente a obrigações, restam-nos apenas o prazer e a necessidade. A necessidade é o que leva os alunos a procurarem cursos para leitura, e muitas vezes também o prazer de aprender. Ainda segundo BALBONI (1994: 77), pode-se dividir as necessidades em três tipos: necessidades futuras (o que o aluno poderá fazer com a língua futuramente), formativas (relacionadas à formação do ser humano e às diferenças socioculturais) e atuais (necessidades durante a aula e o processo de aprendizagem do novo idioma, por exemplo). Essa motivação deve ser constantemente trabalhada, e isso pode ser feito no início do curso, no início de cada unidade e durante a aula. Ela pode ser aliada à outra motivação, que é a ligada ao prazer, o que torna a aula mais proveitosa e também aumenta o rendimento dos alunos em geral. O prazer pode ser de vários tipos, como o prazer de aprender, característica do ser humano; o prazer de superar desafios, ou seja, de cumprir uma tarefa; o prazer da variedade em sua primeira acepção, ou seja, o interesse por outras culturas e modos de viver e de pensar; o prazer da variedade em sua segunda acepção, ou seja, tarefas variadas para que os alunos não se cansem ou se sintam desmotivados; o prazer de sistematizar e compreender, já que é próprio do ser humano buscar leis e princípios que regulem um determinado evento ou sistema, também linguiístico; e o prazer do jogo.

KELLER (1983) apud SÁNCHEZ (1993: 113) aponta quatro fontes de motivação ${ }^{71}$ : o interesse por parte do aluno; a importância para ele daquilo que vai aprender; as expectativas em relação ao que aprende; e o resultado final. Já dentre os fatores externos aos indivíduos, outros que parecem influenciar a motivação de forma destacada são os materiais, as atividades desenvolvidas e os professores. A partir de questionários que analisou, SÁNCHEZ (1993: 117) concluiu que o conteúdo e o procedimento parecem ser os centros em torno dos quais estão os traços motivadores, e que atividades / exercícios que têm como foco a forma lingüística são em geral pouco motivadores.

VAN PASSEL (1983: 33), por sua vez, diz que “a motivação é um fator principalmente externo: cabe ao professor a tarefa de transformá-la em motivação didática, de lhe acrescentar uma motivação interna." Segundo o mesmo autor, esse trabalho com o aluno

\footnotetext{
${ }^{71}$ DITTMAR (1995: 109) fala em "Lernenergie”, "energia para o aprendizado".
} 
"de condicionamento psicológico positivo" é quase tão relevante quanto o conteúdo a ser ensinado / aprendido.

A motivação parece ser tão importante que, conforme nos lembra SÁNCHEZ (1993:112), “quienes desean aprender algo, lo logran a pesar del profesor, a pesar de los libros de que se valga o a pesar del entorno.” Mesmo sendo esse o caso, pode-se - e deve-se - buscar motivar os alunos. Ainda segundo SÁNCHEZ (1993: 114), favorecer a motivação é “contribuir a poner en acción el mayor número posible de resortes de la propia persona con el fin de alcanzar un fin determinado, o, simplemente, para realizar algo." Mas é importante lembrar que ela por si só não é garantia para o aprendizado. SLAMA-CAZACU (1979: 98) lembra que há diversos fatores que influem no ensino/aprendizagem de línguas estrangeiras, como a situação, os processos psíquicos de aprendizagem, os fins, a idade do aluno, o professor, o método, o material, além da motivação. STERN (1983: 384) apud DICKINSON (1987: 29-30) também fala das atitudes específicas do grupo, dos motivos para a aprendizagem da língua, dos fatores afetivos relacionados e de motivação extrínseca e intrínseca. Dentre os motivos, há o instrumental (que é o caso de alunos de cursos para leitura) e o integrativo (que é o que acontece com pessoas que vão viver em outros países e precisam integrar-se).

BOHN (1988b: 294) ainda nos alerta para o fato de que "o professor somente conseguirá ensinar por 'consentimento' do aluno”. E, segundo SMITH (1989: 230), a motivação é relevante porque coloca os aprendizes "em situações onde demonstrações apropriadas tendem a ocorrer", e certamente não haverá aprendizado se não houver o desejo de aprender e a abertura para isso. Destarte, mesmo não sendo o único fator relevante, a motivação é certamente um elemento chave que não pode ser descartado.

SLAMA-CAZACU (1979: 117) ainda nos lembra de que:

(...) "o professor representa também um fator importante na criação (ou modificação, positiva ou negativa) da motivação. Tem não somente a incumbência de estimular o interesse dos alunos através de métodos didáticos apropriados à criação de motivações, mas também a de realizar um certo clima emocional favorável à aprendizagem (se assim não o fizer, poderá, ao contrário, entravar a comunicação).”

O papel do professor como alguém que se interessa pelos alunos genuinamente não deve ser desprezado. Além desse lado humano, que sempre deve existir, SÁNCHEZ (1993: 146) afirma que o professor deve: 
- possuir bases pedagógicas necessárias para compreender a natureza do processo discente/docente, o papel e as necessidades dos alunos, etc.;

- saber discernir quais os objetivos, não só de natureza lingüística;

- $\quad$ ser capaz de analisar, compreender e preparar atividades que estão em conformidade com os objetivos dos alunos / do curso;

- $\quad$ saber que a motivação tem um papel importante e tentar ativá-la.

Dentre as tarefas do professor de um curso para leitura estão, com base em ALMEIDA FILHO (1993), o planejamento, a produção / seleção de material, e a avaliação de rendimento dos alunos (também auto-avaliação dos alunos e do professor). CELANI (1997) apud CARVALHO (2005) diz que o professor de um curso instrumental, que aqui chamamos de curso para leitura, tem que ser pesquisador, elaborador de programas, autor de matérias, examinador, avaliador, professor de estratégias, "empatizador", analista, observador de sua prática, explorador da realidade e experimentador da realidade. CARVALHO (2005) também diz que:

\begin{abstract}
"Além disso, é importante que o professor de instrumental não só apresente conhecimentos lingüísticos e pedagógicos, mas que tenha percepções, uma postura reflexiva diante do que acontece em sala de aula e a sensibilidade de ver seus alunos como seres humanos (KOIFMAN, JUSTO e KERR, 1996: 176). É extremamente relevante que o professor (...) seja menos individualista e se considere inserido em uma coletividade, atitude indispensável para que ele seja um educador atuando dentro de uma realidade (REES, 1995: 134).”
\end{abstract}

O professor, assim, assume um grande número de papéis, pois é o encarregado do planejamento do curso e da aula, da elaboração do material, da determinação da progressão linguiística / gramatical e do léxico a ser trabalhado, da escolha das formas de trabalho em sala de aula, da criação de uma atmosfera agradável, do trabalho com as diversas estratégias, do despertar e da manutenção da motivação, da avaliação de si mesmo e dos alunos, da percepção das dificuldades e de possíveis soluções, do despertar do interesse e do desenvolvimento para a autonomia.

Para poder fazer tudo isso e para que a motivação se mantenha, o professor deve conhecer seus alunos. Uma forma de fazer isso é, como já mencionamos, elaborar previamente um questionário que leve em conta os objetivos dos aprendizes em relação ao aprendizado daquela língua, sua área de atuação, seus interesses profissionais e pessoais, seus 
conhecimentos prévios e o tempo de que dispõem para fazer o curso e para estudar em casa. Através desse questionário é possível, assim, conhecer melhor o público e estabelecer metas, bem como ter diretrizes para a escolha de textos segundo as necessidades e interesses do grupo. E, desse modo, o professor poderá realizar um bom trabalho dentro e fora de sala de aula e permitir que o aluno se torne autônomo - que é do que trataremos no próximo item. 


\subsection{Autonomia}

Autonomia é uma palavra que tem sido muito utilizada não só na aprendizagem de idiomas, mas na educação em geral. Fala-se muito em educar para a autonomia, em "aprender a aprender", mas muitos professores não sabem como fazê-lo. De um ensino totalmente guiado, deseja-se, de repente, que o aluno "se vire" sozinho, que descubra como tomar suas próprias decisões, como monitorar sua aprendizagem, que utilize as mais diversas estratégias. Entretanto, o caminho para a autonomia não se dá de um dia para o outro: é necessário que ele seja percorrido devagar e sempre. O professor vai mostrando as possibilidades e passando aos poucos a responsabilidade ao aluno; este, também aos poucos, vai assumindo essa responsabilidade - até que tenha bases sólidas para exercer sua autonomia.

Mas o que é autonomia? HOLEC (1979: 3) apud SÁNCHEZ (1993: 35) diz que autonomia é "la capacidad de cada uno para responsabilizarse de su propio aprendizaje." DAM (1990: 190), por sua vez, afirma que, para se chegar à autonomia, deve-se: oferecer uma educação que ensine o aluno a aprender, a tomar as decisões importantes para seu aprendizado e a assumir responsabilidade por ele; preparar o aluno para mais tarde, para um estágio de independência; ajudar o aluno a desenvolver ao máximo sua capacidade.

Esse estágio de independência seria a auto-instrução. Em se tratando de cursos para leitura, o aluno poderá, após terem sido estabelecidas bases sólidas, escolher por si só o que e como estudar. Isso é muito importante para que o aluno possa ler o que quiser e para que continue estudando o idioma, principalmente se o curso oferece uma baixa carga horária e um número reduzido de módulos, que foi o nosso caso.

DICKINSON (1987: 5) diz que auto-instrução (self-instruction) é um termo utilizado para "refer to situations in which a learner, with others or alone, is working without the direct control of a teacher."72 A mesma autora (1987: 8) afirma que a auto-instrução envolve responsabilidade pelo aprendizado, pois aprendizes que trabalham com auto-instrução assumem uma responsabilidade maior, que normalmente seria do professor.

Acreditamos que levar o aluno em direção à autonomia pode prepará-lo, ao final, para a auto-instrução, o que, no nosso caso, é importante por diversas razões, inclusive de cunho mais prático: para alunos que não têm outras opções (não há cursos exatamente como o que querem ou não podem ir às aulas), devido a diferenças individuais entre os alunos (em termos

\footnotetext{
72 “(...) se referir a situações nas quais um aprendiz, com outros ou sozinho, está trabalhando sem o controle direto de um professor.” (tradução minha)
} 
de aptidão, estilos cognitivos e conhecimentos, por exemplo), para atender necessidades pessoais, ou porque os objetivos do curso não condizem (exatamente) com aquilo que desejam.

Para que o aluno aprenda a aprender e chegue a um estágio autônomo, FLAVELL (1979: 906) apud DICKINSON (1987: 34) sugere o trabalho com o que chama de metacognição: o desenvolvimento de conhecimentos sobre o processo de aprendizagem, que inclui conhecimento metacognitivo (o que o aluno sabe sobre aprender e como o faz), experiências metacognitivas (experiências cognitivas ou afetivas conscientes que acompanham qualquer exercício intelectual, como perceber se algo não foi compreendido), percepção de metas ou tarefas (quais os objetivos de uma atividade), ações ou estratégias (como alcançar os objetivos).

Em relação ao material para a auto-instrução, DICKINSON (1987: 37) diz que ele pode ser selecionado por um aluno (com a ajuda de um tutor), ou então o aprendiz recebe o material apropriado para suas necessidades, que é o que acontece em cursos para leitura. Já no que diz respeito ao ensino / aprendizagem da língua, a mesma autora (1987: 68) diz que é mais efetivo utilizar materiais autênticos, pelo menos após o aluno já ter uma base lingüística, e que fazê-lo, apud RILEY (1981a):

“(...) makes it possible to meet the learners' needs accurately and economically since by choosing documents of the type that the learner encounters or will encounter in her professional area, she is able to concentrate on their lexical, grammatical, functional and interactional characteristics without wasting time on irrelevant problems. ${ }^{73}$

HOLEC (1980: 27) apud DICKINSON (1987), ao tratar da preparação para a autoinstrução, ainda fala em preparação psicológica e em preparação prática ou metodológica. Ele diz que a preparação psicológica é um processo de "descondicionamento" gradual, através do qual o aprendiz pode deixar de lado preconceitos e idéias equivocadas a respeito do aprendizado de idiomas, como a idéia de que há um método ideal e que o professor o possui; além disso, essa fase tem como objetivo estimular a autoconfiança dos alunos - que devem sentir, afinal, que seu aprendizado será bem-sucedido. A preparação prática, ou metodológica, seria o trabalho efetivo em sala de aula, que, a nosso ver, envolve um eterno questionar: como

\footnotetext{
73 “(...) torna possível ir ao encontro das necessidades do aprendiz de maneira precisa e econômica, já que, escolhendo documentos do tipo que o aprendiz encontra ou encontrará em sua área profissional, ele/ela é capaz de se concentrar em suas características lexicais, gramaticais, funcionais e interacionais sem perder tempo com problemas irrelevantes." (tradução minha)
} 
você fez a atividade? Que estratégias utilizou? Por quê? Que outras poderia ter utilizado? Quais dificuldades surgiram? O que você fez para solucionar os problemas?, etc.

No caso de cursos para leitura, devido à freqüente baixa carga horária, é possível, e até desejável, trabalhar com materiais e desenvolver atividades que ajudem o aluno a se tornar autônomo e a caminhar rumo à auto-instrução.

Mas e o trabalho em um curso para leitura? Como ele se dá na prática? 


\section{O trabalho em um curso para leitura: teoria e prática}

Para o trabalho prático do professor na preparação de seu curso, buscaremos inicialmente aplicar as concepções teóricas até aqui discutidas. Em cada item daremos exemplos retirados de um curso ministrado no ano letivo de 2006, através do Centro de Línguas da Faculdade de Filosofia, Letras e Ciências Humanas da Universidade de São Paulo, bem como exemplos criados após essa experiência. Tal curso foi por nós aplicado e elaborado em dois módulos, tendo como título inicial "Leitura de Textos em Alemão para Filosofia e Ciências Sociais". Esse título foi posteriormente mudado para "Curso de alemão para a leitura de textos de Filosofia e Ciências Sociais", mudança efetuada devido a uma certa confusão causada pelo título inicial: alguns alunos, inclusive com conhecimento prévio do idioma, pensaram que logo no início já leriam textos em alemão e que discutiriam sobre os temas. Com a troca de nome, buscamos deixar claro que se tratava de um curso de língua alemã voltado para a habilidade de leitura de textos das áreas do saber em questão, e não de um curso de Filosofia e Ciências Sociais em alemão.

Partiremos agora das concepções teóricas anteriormente apresentadas. Se pensarmos em língua como um conjunto de estruturas fonológicas, lexicais e morfossintáticas utilizado como instrumento de comunicação e de representação, veremos que os dois lados da moeda devem ser considerados durante o trabalho com textos: tanto a questão estrutural quanto a “mensagem" transmitida pelo texto, ou melhor, o sentido que se pode construir a partir dele. É tendo essa visão de língua que veremos o texto duplamente, e isso influenciará o trabalho em sala de aula.

No que diz respeito à língua no sentido estrutural, deve ser feito um trabalho com as estruturas gramaticais e o léxico, ou seja, deve-se trabalhar com as regras de funcionamento interno do idioma e ampliar o vocabulário do aluno. É importante lembrar que a gramática trabalhada é uma gramática de funcionamento da língua, com elementos da norma culta (já que textos costumam obedecer a essa norma), reduzida (já que os aprendizes não verão a mesma gramática de um curso voltado também à produção), receptiva (já que não haverá produção por parte dos alunos), explícita (após a análise de exemplos pelos alunos) e escrita (o que envolve a gramática da frase e a textual). A chamada progressão gramatical de um curso para leitura difere daquela de cursos comunicativos, pois estruturas recorrentes em textos nem sempre são logo introduzidas em outros cursos. É necessário que se avaliem quais os fenômenos lingüísticos mais freqüentes nos gêneros e tipos textuais em questão e qual seria 
uma sequiência adequada de apresentação. ${ }^{74}$ Também entra em questão o vocabulário técnico $^{75}$ da área, em se tratando de cursos stricto-sensu, que o professor deve pesquisar, explorando-os no momento de aprendizado da língua e também da compreensão do texto. Muitos deles podem até já ser conhecidos dos alunos. Na verdade, trabalhar com o conhecimento de mundo e com o conhecimento específico da área, o que é comum em cursos stricto-sensu, pode ser bastante motivador, já que o aluno pode entender boa parte do texto por já conhecer o assunto.

No curso para leitura ministrado por nós, consultamos, para o primeiro módulo, materiais pré-existentes para estabelecermos uma seqüência gramatical e também de vocabulário, sendo que no segundo módulo partimos de textos indicados pelos alunos. Essa preparação mostrou-se difícil principalmente pela pouca pesquisa em relação a textos de ciências humanas, o que se deve também ao caráter aparentemente não-técnico de tais textos. Há alguns estudos a respeito para o alemão, conforme SCHRÖDER (1988: 43 -80), mas ele mesmo chega à conclusão de que não há um tipo de texto de ciências humanas exemplar. $\mathrm{O}$ vocabulário não se deixa pré-determinar, a não ser o realmente técnico e as palavras gramaticais. Em sua análise desses textos, o autor concluiu que os substantivos são as palavras lexicais mais importantes e numerosas, e que a coerência se dá bastante pelo conteúdo, com numerosas pressuposições. MEYER apud COIRIER et al. (1996: 90), por sua vez, assinala que não se pode definir uma estrutura canônica para textos expositivos.

A seqüência inicial de textos e conteúdos lingüísticos foi determinada com base em cursos pré-existentes, como já dito, aos quais tivemos acesso: Lesekurs für Geisteswissenschaftler, de Marie-Luise Brandi e Barbara Momenteau (com glossários para o inglês e para o francês); Bausteine Fachdeutsch für Wissenschaftler, de Gerhard Fuhr, curso com vários volumes para diversas áreas do conhecimento, sendo que o material de Filosofia por nós consultado foi elaborado por Christian Hamm; Lesekurs Deutsch im Bereich der Geisteswissenschaften für Studierende an brasilianischen Universitäten, de Angelika Gärtner; Alemão Científico: primeiros passos, de Arnold von Buggenhagen; e o material utilizado pela Prof. Dra. Eliana Fischer nos anos de 1986 a 1991 em cursos ministrados no Departamento de Filosofia da Universidade de São Paulo. Não adotamos nenhum desses materiais porque queríamos construir um curso novo, segundo nossas próprias concepções e com base nos interesses dos alunos. Também tivemos acesso ao Planejamento Piloto: Curso Básico de Leitura em Alemão para Fins Acadêmico-Científicos (exemplificado em curso para

\footnotetext{
${ }_{74}^{74}$ Para características do italiano escrito, ver BALBONI (1994: 244-245).

${ }^{75}$ Para textos jornalísticos e suas diversas áreas, ver os sottocodici estabelecidos por DARDANO (1981).
} 
estudantes de Filosofia), elaborado em 1989 por Maria Salette Mayer de Aquino Giuliano e Paulo Sampaio Xavier de Oliveira, e coordenado pelo Prof. Dr. José Carlos Paes de Almeida Filho e pela Prof. Dra. Marilda Cavalcanti, da Universidade Estadual de Campinas. Foi, assim, com base nesses materiais que começamos a preparar os textos e atividades com que trabalhamos.

Partindo agora da concepção de texto como um todo significativo cujo sentido vai ser construído pelo aluno-leitor, este deve perceber desde o início que a soma de palavras não implica necessariamente num sentido final. Por isso, não deve se prender a todas as palavras do texto nem se ater somente ao que não entende, mas sim àquilo que compreende. É importante que o texto permita que algumas informações novas possam ser descobertas através do que já se conhece, tanto em termos de estruturas quanto em termos de significado. Vale lembrar que, para escolher um texto bem estruturado, o professor pode tomar como base os fatores de textualidade que mencionamos anteriormente. Além disso, é importante que se saiba escolher o tipo de texto (autêntico, fabricado ou adaptado), o gênero textual (artigo de jornal, texto acadêmico, carta, manual de instrução, etc.) e o tipo de texto (informativo, descritivo, argumentativo, narrativo, explicativo, instrutivo, preditivo, conversacional, retórico) segundo as necessidades e interesses do grupo.

A ordem de gêneros textuais por nós escolhida no curso ministrado (para o primeiro módulo) foi a seguinte: lista de aulas de uma universidade alemã, bibliografias, citações, descrições de livros, biografias de autores importantes, e definições de enciclopédias e dicionários. Para o segundo módulo utilizamos trechos de textos indicados pelos alunos, como já dito. Todos os textos do módulo I foram retirados da Internet, com exceção das definições, retiradas do Lexikon der Allgemeinbildung (2000), da Duden.

Voltando à teoria e partindo da concepção de leitura como interação do leitor com o texto, é necessário que fique claro para o aluno que nem todas as informações estão explícitas textualmente, mas que muitas dependem do conhecimento de mundo que ele traz consigo. É necessário que os conhecimentos lingüísticos sejam ampliados e que os conhecimentos de mundo sejam aplicados. Para isso devem ser desenvolvidas estratégias e as diversas competências de que aqui tratamos, e trabalhados diversos tipos de compreensão.

No nosso curso, a ordem dos gêneros textuais e a sequiência apresentada foi a seguinte, no módulo I:

\section{Texto 1: Lista de aulas na universidade}

Compreensão textual: global, seletiva 
Aspectos lingüísticos: pronúncia; substantivos; internacionalismos; substantivos compostos (morfologia - sufixos); adjetivos (posição e morfologia - sufixos); artigos e gêneros; casos nominativo e genitivo (artigos definidos, indefinidos e adjetivos); noções de plural; vocabulário de dias da semana, meses, números, estações do ano, matérias e ciências; coerência sem coesão.

\section{Texto 2: Bibliografias}

Compreensão textual: seletiva, total

Aspectos lingüísticos: introdução a perguntas com pronomes interrogativos ( $W$ Fragen), introdução a conjunções e preposições, introdução aos casos acusativo e dativo; introdução a verbos; vocabulário relacionado a livros (edição, página); coerência sem coesão.

\section{Texto 3: Citações}

Compreensão textual: total

Aspectos lingüísticos: verbos regulares e irregulares no presente, verbos modais, imperativo, pronomes pessoais, pronomes possessivos, pronome "man", posição do verbo (introdução a orações subordinadas), verbos com prefixo separável (morfologia - prefixos), negação, conjunções e preposições; vocabulário geral; anáfora (pronominal).

\section{Texto 4: Descrição de obras}

Compreensão textual: global, seletiva, total

Aspectos lingüísticos: comparativo e superlativo dos adjetivos, verbos e pronomes reflexivos, casos acusativo e dativo (diversos usos), introdução ao passado (Präteritum); vocabulário geral; coesão e coerência (conhecimento de mundo).

\section{Texto 5: Biografias}

Compreensão textual: seletiva, total

Aspectos lingüísticos: formas de passado (Präteritum e Perfekt), particípio passado (Partizip II), introdução a orações relativas e "Infinitiv mit zu", orações coordenadas e subordinadas, conectores; vocabulário geral; coerência e coesão por conectores.

\section{Texto 6: Definições}

Compreensão textual: seletiva, total 
Aspectos lingüísticos: orações relativas e pronomes relativos, voz passiva, verbo “werden”, "Infinitiv mit zu”, advérbios pronominais; vocabulário geral; coesão e coerência, referências.

No módulo II trabalhamos com os seguintes pontos gramaticais, retirados de textos escolhidos pelos alunos: "Konjunktiv" I e II, Pretérito mais-que-perfeito (Plusquamperfekt), futuro (Futur I e II), particípio presente (Partizip I), construções participais e com infinitivo, e com mais orações coordenadas, subordinadas e conectores, além de revisarmos os pontos apresentados no primeiro módulo.

Essa ordem gramatical foi estabelecida, nos dois semestres, de acordo com as construções que foram aparecendo nos textos. Iniciamos, como se costuma fazer, com substantivos e substantivos compostos, alguns sintagmas e verbos no presente, e a partir daí os pontos gramaticais foram sendo apresentados à medida que surgiam nos textos. Esses aspectos gramaticais eram retomados à medida que reapareciam nos novos textos, ao mesmo tempo em que novos pontos eram apresentados. O tempo de apresentação foi muito mais curto do que o que costuma acontecer em cursos comunicativos, já que os alunos deveriam apenas reconhecer as estruturas, sem ter que produzir. Já o vocabulário foi sendo apresentado e memorizado também de acordo com seu aparecimento nos textos, já que não dispúnhamos de listas ou de uma análise que nos indicasse quais palavras seriam mais freqüentes em textos da área. Não foi possível, assim, predeterminar o vocabulário ou dividi-lo em temas, com exceção das primeiras aulas.

Os tipos de compreensão foram trabalhados alternadamente, dependendo do tipo de texto. Alguns textos apresentaram mais de uma possibilidade, o que nos fez trabalhar de forma concêntrica ${ }^{76}$ - ou seja, trabalhamos inicialmente com um tipo de compreensão (global ou seletiva) e voltamos mais tarde ao mesmo texto para trabalhar com outro tipo (seletiva ou detalhada, respectivamente). Sobre as estratégias e atividades falaremos mais tarde.

Mas por que selecionamos esses gêneros textuais e em que mais nos baseamos, além do material já aqui exposto? Como "concretizamos" esse material? Pudemos fazer uma seleção mais adequada, ou, pelo menos, mais motivadora, após a leitura dos questionários respondidos pelos alunos no primeiro dia de aula, sobre o que falaremos a seguir.

\footnotetext{
${ }^{76}$ É o que WESTHOFF (1997: 107) chama de "konzentrisches Lesen”, ou "leitura concêntrica".
} 


\subsection{Primeiro contato}

Embora tivéssemos um plano inicial - e é interessante que o professor tenha um, para poder se orientar melhor e ter objetivos mais claros e viáveis -, grande parte do material e das aulas foi planejada de acordo com os interesses e necessidades dos alunos, após a leitura dos questionários por eles respondidos. Em um curso tão específico o professor deve buscar atender as necessidades e desejos do grupo, e para isso deve tentar conhecê-los - o que pode ser feito através de um questionário como o exemplo a seguir:

\begin{tabular}{|l|}
\hline Nome: \\
\hline Data de nascimento: \\
\hline Profissão / curso: \\
\hline Telefone / e-mail: \\
\hline 1. Que línguas você conhece? Em que nível está? \\
\hline 2. Por que você se interessou em fazer este curso? \\
\hline 3. Que tipos de textos e que autores você precisa / gostaria de ler no idioma que vai \\
aprender? \\
\hline 4. Que autores / obras da área você já leu? (em qualquer língua) \\
\hline 5. O que você costuma ler? Com que frequiência? Faça uma pequena lista. \\
\hline 6. Qual a sua área de atuação? Especifique. \\
\hline 7. Quais são suas áreas de interesse? \\
\hline 8. Quais são seus hobbies? \\
\hline 9. Quanto tempo por semana você tem disponível para estudar? \\
\hline 10. O que você espera do curso? \\
\hline
\end{tabular}

Através da pergunta 1 o professor pode saber quais os conhecimentos lingüísticos dos alunos, que fazem também parte do seu conhecimento prévio e que podem auxiliar na leitura e na aprendizagem. A pergunta 2 busca descobrir o que levou os alunos a fazerem o curso, e, juntamente com a pergunta 3 , ajuda o professor a elaborar as aulas e os materiais de acordo com os interesses e necessidades dos alunos. A pergunta 4 diz respeito aos conhecimentos prévios do aluno, enquanto a pergunta 5 busca investigar os hábitos de leitura do grupo, para se ter uma idéia da proficiência dos alunos em relação a essa habilidade. Através das 
perguntas 6, 7 e 8 tenta-se conhecer melhor os alunos e, com isso, buscar determinar quais seus principais objetivos e também criar um clima agradável em sala de aula. A pergunta 9 diz respeito ao dever do aluno de estudar, sobre o qual se deve conversar no primeiro dia de aula, e que pode ser uma das causas de desempenhos diferentes (aspecto que só pode ser examinado posteriormente). Já a pergunta 10 tenta extrair dos alunos quais suas expectativas, para ver se elas são semelhantes entre si e se estão relacionadas aos objetivos realmente estabelecidos pelo curso.

Para exemplificar, apresentaremos as respostas dos nossos alunos. É importante ressaltar que, embora tenha sido pedido para que dessem respostas completas e para que todas as questões fossem respondidas, isso nem sempre aconteceu. 


\subsection{Grupo}

Após a leitura dos questionários, é interessante que o professor faça uma análise de seu grupo e das respostas dadas, principalmente para poder escolher textos que interessem à maioria. Apresentamos aqui um exemplo de como pode ser um grupo e de como fazê-lo.

No nosso caso, após a fase inicial de inscrições, o curso passou a ter, mais ou menos a partir da terceira semana, vinte e sete alunos. Inicialmente deveriam se inscrever apenas pessoas das áreas de Filosofia e Ciências Sociais, mas mais tarde a inscrição foi aberta para todos para preenchimento das vagas. Dos vinte e sete alunos, dezenove concluíram o primeiro módulo. Logo no início houve uma desistência, pois o aluno em questão esperava um outro tipo de curso. Ao longo do semestre mais seis alunos desistiram. Dois deles entraram em contato com a professora alegando falta de tempo e uma aluna disse estar com problemas pessoais; os outros não se manifestaram para explicar os motivos da desistência.

Na primeira aula, após as apresentações, foi explicado o que era um curso para leitura, do que a maioria dos alunos parecia estar consciente. Embora o curso fosse voltado para iniciantes no idioma, alguns alunos disseram já ter base de alemão, e uma aluna se surpreendeu ao saber que começaríamos do zero, pois ela já tinha feito alguns níveis do curso básico. Atribuímos essa confusão ao nome inicial do curso, "Leitura de Textos em Alemão para Filosofia e Ciências Sociais", mudado então para "Curso de Alemão para Leitura de Textos de Filosofia e Ciências Sociais", sendo que abdicamos da terminologia instrumental ou qualquer outra semelhante, conforme anteriormente explicado. Procuramos com o novo título enfatizar que seria um curso de língua voltado para a leitura de textos, ou seja, tendo como objetivo a habilidade de ler textos em alemão das áreas em questão.

Em relação aos conhecimentos lingüísticos, apenas 1 aluno não mencionou ter estudado inglês. Os outros responderam: inglês básico (3), inglês intermediário (4), inglês fluente / avançado (8). Seis mencionaram apenas "inglês", um mencionou "inglês bom" e 4 mencionaram inglês para leitura, mas não pudemos saber se esses conhecimentos foram adquiridos através de cursos para leitura ou de forma autodidática. Francês foi a segunda língua mais mencionada: francês básico (5), francês intermediário (3), francês avançado (2), francês fluente (2), francês para leitura (7). Em seguida veio o espanhol: 3 alunos escreveram apenas "espanhol"; houve ainda espanhol básico (2), espanhol intermediário (3), espanhol fluente (1), espanhol para leitura (7), e uma aluna tinha o espanhol como língua materna, sendo fluente em português. Além dessas línguas, quatro mencionaram o italiano: italiano 
básico (1), italiano intermediário (2), italiano para leitura (1). Dois alunos mencionaram latim, dois mencionaram grego, e uma ainda disse ter nível básico de chinês. Uma aluna também sabia húngaro (língua materna juntamente com o português) e um aluno sabia tcheco (língua materna juntamente com o português). Além disso, alguns alunos já tinham conhecimentos de alemão, conforme as respostas abaixo:

- baixo nível de leitura;

- conhecimentos básicos adquiridos em um curso "instrumental” feito há muitos anos;

- dois semestres de aula;

- alemão básico;

- básico quase completo;

- curso básico completo;

- nível básico;

- quase intermediário.

Ou seja, oito alunos já tinham conhecimentos de alemão, e todos os alunos sabiam pelo menos uma língua estrangeira, tendo estudado (ou tido contato) em média com três línguas, além da materna.

Em relação ao interesse pelo curso, 8 alunos disseram querer ler textos em alemão, 6 disseram explicitamente querer ler textos da área de Filosofia em alemão, 2 disseram querer aprender o básico da língua / ter noções do idioma, 1 mencionou querer ler literatura, 1 queria ler Freud em alemão, 1 queria estudar na Alemanha, 1 mencionou contatos na área de Engenharia e 1 queria ler textos de Química. Excetuando três casos, um engenheiro (que queria contatos na área de Engenharia), um estudante de Química (que queria ler textos de Química) e uma estudante de Biologia (que queria ter noções de alemão), todos os outros se encaixavam mais especificamente nos objetivos do curso. Havia também uma advogada, interessada em textos não tão ligados ao curso, mas que também queria ler sobre Filosofia do Direito e prestar a prova de proficiência para o mestrado, assim como uma aluna formada em Letras. O engenheiro, que tinha tcheco como língua materna, desistiu logo após a primeira aula, alegando não ter atentado para o enfoque do curso antes da matrícula. O estudante de Química desistiu antes do final do semestre, embora estivesse tendo um bom desempenho, e a estudante de Biologia terminou o primeiro semestre, mas não se matriculou no segundo. A advogada também saiu, alegando motivos pessoais. Ou seja, ao final restaram apenas pessoas 
de áreas mais relacionadas ao enfoque do curso: Filosofia e Ciências Sociais, além de Psicologia e Letras.

Todos os alunos mostraram hábitos de leitura freqüentes, também no que diz respeito a textos da área de Filosofia e Ciências Sociais. Apenas o estudante de Química mencionou ler apenas textos técnicos, e a estudante de Biologia disse não ler textos da área de enfoque do curso.

Os autores mais mencionados pelos alunos como já lidos foram Kant (9), Marx (6), Adorno (6), Horkheimer (5), Hegel (5), Nietzsche (3), Schopenhauer (3), Heidegger (3), Freud (3), Husserl (2), Fichte (2), Goethe (2), Kafka (2). Os autores que os alunos mais gostariam de ler: Hegel (8), Kant (7), Marx (6), Goethe (5), Heidegger (5), Adorno (4), Benjamin (4), Freud (3), Husserl (3), Wittgenstein (3), Koffka (2), Kohler (2), Nietzsche (2), Schopenhauer (2), Fichte (2). Essa enumeração foi importante para a escolha de textos que estivessem relacionados a esses autores ou a suas obras.

Quanto às áreas de atuação dos alunos: estudantes de graduação de Filosofia (3); mestrandos em Filosofia (2); professor e mestrando em Filosofia; professor de Filosofia e Teologia; professor e pós-graduando em Psicologia; psicóloga e doutoranda em Filosofia; músico e tradutor de Filosofia e Teologia; advogada e filósofa; professor secundário e doutorando em Filosofia; doutorando em Filosofia da Educação; sociólogo e mestrando em Ciência Política; servidor público de fundação que realiza estudos socioeconômicos; economista, tradutora e mestranda em Tradução; revisora e editora de textos formada em Letras; estudante de graduação de Biologia; estudante de graduação de Ciências Sociais (2); professor de Literatura Portuguesa; advogada; estudante de graduação de Química; professora de Filosofia e mestranda; jornalista na área de comunicação (jornalismo escrito) e cursos de filosofia in company; estudante de graduação de Geografia. Os desistentes foram os últimos seis mencionados e um estudante de Ciências Sociais. A estudante de Biologia, como já foi dito, concluiu o primeiro semestre, mas não se matriculou no segundo. Como a maioria dos desistentes não era da área a que o curso se volta, acreditamos que tenham desistido por não estarmos trabalhando com textos que fossem interessantes para eles, ou então por motivos pessoais.

À pergunta “o que você espera do curso?” foram dadas as respostas abaixo. Embora algumas delas sejam semelhantes, acreditamos que seria interessante expor todas para dar uma idéia melhor do que os alunos realmente esperam de cursos para leitura:

- ter noções do alemão, aprender um pouco de pronúncia e gramática 
- desenvolver habilidade de leitura de textos técnicos e adquirir conhecimentos sobre a estrutura do idioma

- aprender a ler em alemão e conhecer a estrutura gramatical da língua

- que me ofereça instrumentos para a leitura de textos filosóficos e teológicos em alemão

- aprimorar minha capacidade de leitura em alemão

- ler em alemão

- aprender a estrutura da língua para poder identificar as palavras nos textos que preciso ler e entender o significado exato dos autores alemães

- a maior habilidade possível para ler os textos alemães

- os fundamentos essenciais para a leitura do alemão

- aprender os fundamentos da língua escrita em alemão

- espero conseguir um empurrão para começar a ler textos em alemão. Espero que nas aulas trabalhemos com os textos e que as atividades em sala sejam principalmente individuais, para que os diferentes ritmos possam ter espaço.

- aprender a ler textos em alemão com o mínimo possível de competência

- desenvolvimento de técnicas de leitura; aprofundamento morfológico e sintático (gramática), trabalho com textos filosóficos

- conhecimento básico para leitura de texto

- que me proporcione a capacidade de ler e interpretar textos acadêmicos escritos originalmente em alemão e que me auxiliem no doutorado. Espero que isso possa ser também de importância para um pós-doutorado na Alemanha.

- aprofundar minha capacidade de leitura

- aprender a ler textos para a prova de proficiência e posteriormente, no mestrado, leitura jurídica

- espero ferramentas e técnicas suficientes para melhorar minha leitura e compreensão de textos alemães, quem sabe até para fazer tradução para o português

- conseguir ler textos em alemão com o auxílio de um dicionário bilíngüe

- aproximação com a língua

- introdução à língua alemã

- adquirir agilidade e compreensão de textos em alemão

- aprender alemão de uma forma agradável 
- aumentar o conhecimento no alemão, já que estou estudando a língua, e logicamente começar a ficar mais desenvolvida na leitura também

- iniciar o contato com os textos

Pudemos notar que os objetivos, embora um pouco variados em alguns casos, se assemelhavam entre si e condiziam em geral com o objetivo do curso.

Os hobbies e as áreas de interesse não vão ser aqui mencionados, pois serviram para que o professor conhecesse melhor seus alunos como pessoas, para aprimorar o envolvimento do grupo e melhorar a atmosfera das aulas.

Além disso, perguntamos informalmente após algumas aulas se os alunos já haviam feito outros cursos para leitura (os ditos "instrumentais") e como haviam ficado sabendo do nosso curso. A maioria se inteirou a respeito através do site do Centro de Línguas da FFLCHUSP ou por conhecidos que freqüentavam a faculdade, e pelo menos dez alunos já haviam feito cursos para leitura de outros idiomas.

No módulo II entraram quatro alunos novos, provenientes das áreas de Filosofia, Letras, Arquitetura e Ciências Sociais, que não haviam feito o módulo I, mas que já tinham conhecimentos de alemão. Tendo como média o conhecimento de três línguas, além da materna, esses alunos esperavam do curso:

- ler um texto e compreendê-lo, mesmo que com ajuda de dicionário

- habilidade para ler textos de Filosofia

- fixar melhor algumas estruturas da língua alemã e aumentar o vocabulário na área de humanas

- otimizar a leitura de alemão para melhorar os conhecimentos da língua e aprimorar pesquisa.

Os autores mencionados como lidos, em português ou outros idiomas que não o alemão, foram Auerbach, Adorno, Benjamin, Kant, Hegel, Wittgenstein, Hölderlin, Goethe, Simmel e Norbert Elias; dentre os autores que gostariam de ler estavam Nietzsche, Benjamin, Simmel, Heidegger, Handke, Norbert Elias, Ulrich Beck, além de textos da área de Filosofia, Ciências Humanas e Literatura. 
Essa foi a análise inicial dos alunos do curso por nós ministrado, que acreditamos poder guiar o professor tanto na escolha dos materiais quanto nos procedimentos a serem adotados em aula, sobre o que falaremos a seguir. 


\subsection{Material e objetivos}

Baseando-nos em HÄUSSERMANN e PIEPHO (1996: 286-287), acreditamos que o professor deva encontrar textos que possam ser abordados de diversas maneiras, que estejam relacionados aos alunos de várias formas, que tenham temas com os quais os alunos se identifiquem e que possam trazer elementos novos, surpreendentes, que propiciem discussões. Os textos devem levantar questões, abrir portas, ser elementos de formação e reflexão. Além disso, o professor deve mostrar seu entusiasmo pela atividade e estimular a autoconfiança dos alunos através de atividades adequadas, ou seja, nem fáceis nem difíceis demais.

Para o trabalho em sala de aula, deve-se, assim, escolher textos interessantes e estimulantes e formas de trabalho variadas, pensando-se sempre na motivação ligada à necessidade e ao prazer. Ao mesmo tempo, deve-se elaborar uma progressão temática e estratégica, além da lingüística ${ }^{77}$, equilibrando-as. Segundo NEUNER (1990), o professor deve considerar sempre os objetivos a serem alcançados, tanto a curto quanto a longo prazo, e o que os alunos já sabem (em termos de língua, de experiências com os temas e com os tipos de tarefas propostas). Quanto à aula em si, ele ainda propõe que os professores considerem sempre a preparação do material e das aulas (como e quanto tempo têm para tanto), o trabalho em si (quanto tempo de aula), as possibilidades de trabalho (quais tarefas e quais as divisões de grupos, ou seja, qual a forma social de trabalho), e possibilidades de ampliação do que é feito na classe. Aliás, a parte organizacional é um lado muitas vezes esquecido, mas que também deve ser sempre considerado pelo professor: número de alunos, de aulas, o tempo da aula (que influencia diretamente na extensão dos textos e no trabalho), a periodicidade, o tempo total do curso, as possibilidades de diversificação do trabalho em aula (individualmente, em duplas, em grupos), a variedade de tarefas, etc. BOHN (1988b: 295) lembra que é necessário, entre outras coisas, definir as situações e contextos em que os aprendizes vão precisar utilizar a língua estrangeira e listar em ordem de prioridade o que deverá ser trabalhado.

Segundo RICHTERICH (1985: 6) APUD REIS (1990: 6), toda situação de ensino/aprendizagem em meio institucional é formada pelos seguintes componentes: aprendizes, professor, conteúdos, instituição, objetivos, ações, meios e resultados. BOHN (1988b: 292), por sua vez, diz que a aprendizagem de uma outra língua é "um processo complexo com uma porção de variáveis intervencionais, algumas intrínsecas ao próprio

\footnotetext{
${ }^{77}$ Para uma progressão gramatical para o alemão, ver HERINGER (1987).
} 
aprendiz, outras externas e dependentes basicamente do ambiente físico em que se desenvolve a aprendizagem. Tudo isso deve ser levado em conta no período de preparação e execução de qualquer curso.

Para exemplificar um pouco, no curso que ministramos houve duas aulas por semana no primeiro módulo, com cada aula tendo uma duração de noventa minutos. Ou seja, semanalmente os alunos tinham três horas de aula, com um total de 45 horas no semestre. $\mathrm{O}$ curso acontecia às segundas e quartas, das $18 \mathrm{~h}$ às $19 \mathrm{~h} 30$, horário inicialmente escolhido devido aos horários das faculdades em questão: atenderia aos alunos que saíam de seus cursos às $18 \mathrm{~h}$ e aos alunos que entrariam no período noturno, às $19 \mathrm{~h} 30$. No segundo módulo houve apenas uma aula semanal, de duas horas, às segundas-feiras, das $17 \mathrm{~h} 30$ às 19h30, com um total de 30 horas no semestre. Essa carga horária foi determinada pelo Centro de Línguas.

O primeiro módulo aconteceu de 06/03 a 28/06, e o segundo módulo foi de 07/08 a 04/12. O fato de o curso ser em um país distante da Alemanha e onde não se tem muito contato com a língua caracterizava a maioria dos alunos como iniciantes reais, enfatizando a falta de necessidade (pelo menos imediata) de desenvolvimento de habilidades produtivas (fala e escrita). Embora concebido para um público teoricamente homogêneo em relação à área do saber envolvido, o curso era, como ficou claro com a mudança de título, um curso de língua, e não da área em questão, também pelo fato de a professora não ser especialista em Filosofia ou Ciências Sociais; os alunos usariam seus conhecimentos específicos, assim, para compreender os textos e aprender a língua. Foram buscados textos autênticos para introduzir os alunos a um vocabulário mais ligado à área e às estruturas lingüísticas. A língua ensinada foi a língua alemã, através de um recorte: ênfase nas formas lingüísticas aparentemente mais comuns nos gêneros textuais ligados à área bem como no vocabulário específico e aparentemente mais comum em tais textos. ${ }^{78}$ É nesse sentido que concordamos com SCHRÖDER (1988: 2) quando ele diz que "(wir) sehen als den eigentlichen Gegenstand der Fachsprachenforschung (...) den konkreten Fachtext (...)"79 , e para nós é também o texto a base da aula. Mas ele se define tanto no plano do conteúdo quanto da forma, daí também a importância da parte lingüística.

O planejamento foi feito por nós, uma professora sem formação superior na área, mas com interesse por ela, com a ajuda de sua orientadora, sendo destinadas 7 horas semanais para isso. O papel da professora era preparar as aulas de acordo com uma seqüência pré-

\footnotetext{
${ }^{78}$ Dizemos que as estruturas e o vocabulário são aparentemente mais comuns devido à falta de estudos na área.

79،“(Nós) vemos como o verdadeiro objeto da pesquisa de 'línguas especializadas' (...) o texto especializado, concreto." (tradução minha)
} 
estabelecida, mas pensando nos interesses dos alunos. Estes, por sua vez, deveriam comparecer às aulas, participar e fazer as tarefas propostas, conforme combinado no primeiro dia de aula.

O trabalho em sala de aula era feito em grupos, duplas ou individualmente, dependendo da atividade. A ampliação do trabalho feito em classe pouco se deu, devido às muitas atividades a que já se dedicavam os alunos.

Ao final dos dois módulos, os alunos tinham adquirido uma noção das estruturas gramaticais da língua e um vocabulário mais abstrato (geralmente introduzido bem tardiamente em cursos comunicativos) e das áreas do saber envolvidas, e conseguiam determinar a idéia geral de certos textos, encontrar informações específicas em outros e traduzir pequenos trechos com a ajuda de obras de referências como gramáticas e dicionários. Infelizmente não se pôde chegar a uma fluência de leitura devido à baixa carga horária e às dificuldades com a língua alemã - pela falta de contato, pelo pouco tempo de estudo, pela complexidade dos textos e pelas diferenças em relação à língua portuguesa. Acreditamos que uma maior carga horária (pelo menos quatro horas semanais em todos os módulos) e mais tempo de estudo (talvez 4 módulos) seriam necessários para se começar a atingir a fluência. Voltaremos a tratar das dificuldades específicas desse tipo de curso.

No que diz respeito à preparação e execução do curso, é necessário que o professor leve em conta os fatores "externos" para poder ter objetivos viáveis e fazer o possível para alcançá-los. No nosso caso, já que os alunos só teriam dois semestres de aula, pedimos que dessem sugestões de textos para o segundo módulo, para que pudessem ler algo que lhes interessasse mais. Se houvesse mais módulos, isso poderia ser feito mais adiante, com menos pressa, em um momento talvez mais adequado. A nossa decisão foi tomada pensando na motivação dos alunos e na utilidade para eles, e estruturamos a seqüência gramatical e lexical a partir desses textos, quando possível. No primeiro módulo, porém, a escolha do material foi feita exclusivamente por nós, embora tenhamos levado em conta os interesses dos alunos. Como exemplo, ao trabalharmos com biografias, introduzimos pontos gramaticais como o passado e também mais vocabulário, mas aproveitamos para escolher biografias de autores pelos quais muitos dos alunos se interessavam. Sendo assim, tentamos ver o texto tanto como objeto de demonstração para material lingüístico quanto como portador de informação, segundo a classificação de LAVEAU (1985: 18). No caso de cursos para leitura, o texto deve realmente desempenhar ambos os papéis, e por essa razão devem ser feitos trabalhos adequados aos dois tipos de visão. Além disso, como já foi dito, o texto deve permitir que se descubram informações novas através das já conhecidas. Inicialmente isso parece complicado, 
devido à falta de conhecimento lingüístico dos alunos. Mas é importante que o professor saiba propor tarefas adequadas que permitam que os alunos adquiram algum conhecimento lingüístico e também estratégico a partir do que já conhecem, mesmo que seja pouco. Além disso, em se tratando de um curso para leitura, deve-se buscar trabalhar com os diversos tipos de compreensão (total, global e seletiva) e com diversos atos de leitura. Para tanto é necessário que o texto seja bem analisado pelo professor, pois só assim este poderá elaborar atividades condizentes com a natureza do texto e com os objetivos dos alunos e da aula.

Para essa escolha do texto, LAVEAU (1985: 78-90) propõe que se proceda uma análise textual em diversos níveis lingüísticos: morfológica (quais verbos, substantivos e adjetivos, quais as classes de palavras produtoras de relações lógicas, quais elementos podem ser trabalhados e como); sintática (análise das orações principais e subordinadas, e das relações entre elas); lexical (quais palavras são técnicas, quais do vocabulário geral, quais pertencem aos dois grupos); dos "procedimentos de comunicação" compreensão, através de definições, reformulações, repetições, tabelas, figuras, elementos tipográficos) e do plano de construção textual (como o texto é organizado e como pode ser desmembrado). Além disso, deve-se analisar o tipo de texto em relação ao seu gênero e ao seu tipo: informar, descrever, narrar, argumentar... Mais uma vez, é claro que em geral não existem tipos "puros", mas podemos analisar os textos em termos de predominância. No quadro europeu comum de referência para o ensino/aprendizagem de línguas estrangeiras (1998: 126), também se fala das características do texto a serem consideradas, que incluem a complexidade lingüística, o tipo de texto, seu tamanho, a estrutura do discurso, as condições materiais e o interesse do aprendiz. Baseando-nos nisso e em BOHN (1988b: 298), podemos pensar em algumas questões que podem ser feitas ao texto: como o conteúdo do texto está relacionado aos interesses e conhecimentos do aluno? Quais as características do texto em termos de língua, estrutura e conteúdo? Que estratégia de leitura o texto sugere?

Desse modo, essa análise deve ser feita, como foi dito, para que sejam determinadas as características dos textos e suas possíveis dificuldades para os alunos. Estas variam segundo o público leitor, mas também em termos linguiísticos, de registro e em relação ao tema, por exemplo. Por isso também é necessário conhecer os alunos e quais são seus conhecimentos prévios em relação à língua e aos assuntos. Os materiais, assim como os exercícios, devem permitir que os alunos atinjam os objetivos propostos. De acordo com VAN PASSEL (1983: 34), “um (...) erro que desta vez não reside no professor, mas muito no método utilizado ou no

\footnotetext{
${ }^{80}$ Kommunikationsverfahren no original.
} 
livro adotado, consiste em não se definir claramente as metas da aprendizagem." Como o professor é quem escolhe os materiais no caso de cursos para leitura, essas metas devem estar claras e condizer com a proposta. É importante lembrar, também de acordo com VAN PASSEL (1983: 35), que o material é um meio auxiliar, e que "para obter o resultado previsto, o número de horas de participação efetiva tem uma importância infinitamente superior ao número de páginas lidas.” BOHN (1988b: 293), por sua vez, nos lembra que os materiais podem auxiliar no estabelecimento de objetivos e ampliar a quantidade de linguagem disponível na aula, além de colaborar para a definição do conteúdo de um curso, mas "não devem ser os únicos determinantes dos objetivos e nem devem ser a única fonte de conteúdo e de disponibilidade lingüística em sala de aula." Ou seja, eles servem de apoio.

De qualquer forma, é necessário que haja material, mesmo que ele não seja o principal fator. E o material em um curso para leitura é o texto em si. BUHLMANN e FEARNS (1987: 182) propõem quatro dimensões para a escolha de textos, que aqui adaptamos: sprachliche Einfachheit (simplicidade lingüística: grau de língua adequado aos alunos, bem como vocabulário), Gliederung / Ordnung (organização: previsibilidade, clareza e seqüência adequada de pensamento), Kürze / Prägnanz (tamanho e relevância: o texto não deve ser longo nem curto demais e deve ser significativo), zusätzliche Stimulanz (estímulos adicionais: o texto deve ser estimulante, pessoal). ${ }^{81}$

Após analisar os textos e determinar suas características, o professor pode escolher quais pontos vai aprofundar, levando em conta o texto em si e os objetivos dos alunos, bem como o grau de conhecimento destes. Textos de áreas específicas, em caso de cursos strictosensu, podem ser conseguidos através de alunos e de sugestões vindas deles, bem como através de consultas com especialistas da área ou outros estudantes.

No nosso caso, uma diferença em relação aos cursos já existentes e aos materiais em que nos baseamos foi a fonte dos textos: muitos foram retirados da Internet, de sites confiáveis, embora vários deles também estivessem disponíveis em papel (principalmente os textos fornecidos pelos alunos no segundo módulo). Foram utilizados apenas materiais autênticos. Não houve adaptações, apenas seleção de itens ou exclusão de trechos.

O fato de os alunos não terem um material de consulta, embora tenham sido indicadas algumas gramáticas a pedido de alguns, levou à montagem de um blog na Internet, constantemente atualizado de acordo com as aulas, contendo glossário e explicações gramaticais. Além disso, após toda aula os alunos recebiam um e-mail da professora com o

\footnotetext{
${ }^{81}$ Os termos foram adaptados para o português por mim.
} 
assunto do dia e com o link para o site de onde havia sido retirado o texto da aula, quando ele estava disponível na Internet. Acreditamos que a montagem do blog e a comunicação por email tenham sido fundamentais para alguns aspectos importantes em qualquer aula, que são o bem-estar do aluno, o bom relacionamento com os outros e a motivação.

$\mathrm{O} \operatorname{blog}^{82}$ feito na Internet foi montado com as seguintes seções, a seguir especificadas:

- Willkommen! (Bem-vindos!) - breve apresentação do blog.

- Wer sind wir? (Quem somos nós?) - nomes dos participantes.

- Strategien (Estratégias) - apresentação de algumas estratégias de leitura e aprendizagem (cognitivas, metacognitivas, mnemônicas).

- Texte (Textos) - textos utilizados nas aulas (links na Internet e indicações de bibliografia).

- Wortschatz (Vocabulário) - glossário inicial.

- Links (links) - links para sites interessantes: dicionários online, textos e gramáticas na Internet.

- Sonstiges (outros) - indicações de bibliografia.

Todos os textos foram colocados em português. A idéia inicial era que o blog fosse construído por todo o grupo, mas devido ao grande número de alunos, à falta de tempo de vários e à falta de acesso freqüente ao computador por muitos, isso não se deu. Também se notou a posteriori que essa ferramenta poderia ter sido utilizada de uma forma mais integradora ou mesmo "construtora", em vários sentidos, o que não ocorreu. Na avaliação do primeiro módulo, uma das poucas alunas que mencionou o blog separadamente disse que "o blog é muito interessante, é uma maneira a mais de o aluno interagir com o curso, mesmo que só lendo o conteúdo; e os e-mails dão um bom reforço nos conteúdos vistos e ajudam a fixar o estudado em aula."

Essa questão dos e-mails foi muito mencionada nas avaliações e vista como extremamente positiva, embora muitos dos alunos não tenham entrado em detalhes. Voltaremos a falar sobre isso e sobre alguns pontos positivos e negativos do curso.

Tendo sido levados em conta todos esses aspectos para a escolha dos textos, podemos pensar agora na seqüência da aula, ou seja, nas fases do trabalho com os alunos.

82 O blog se encontra no ar até a presente data (junho de 2007) no endereço eletrônico http://lesekurs.blogspot.com e foi atualizado pela última vez no final de 2006. Um novo blog foi feito em seguida, para a turma que iniciou o curso no ano letivo de 2007, com algumas modificações e melhoramentos. Esse segundo blog se encontra até agora em http://lesekurs2007.blogspot.com. 


\subsection{Fases da aula}

O principal objetivo de alguém que lê um texto é compreendê-lo de algum modo. Por isso é interessante trabalhar inicialmente com algum tipo de compreensão do texto para depois se passar para a parte de estruturas e de vocabulário. Essa compreensão pode ser total, global ou seletiva, como já vimos. Com alunos iniciantes, é mais indicado, pela falta de conhecimentos lingüísticos, trabalhar com a compreensão global, para depois passar aos poucos para a seletiva, e mais adiante para a compreensão total. Um mesmo texto também pode ser lido buscando vários tipos de compreensão em momentos diferentes. Ou seja, iniciase com um determinado foco, para depois voltar ao texto com um outro objetivo, de forma concêntrica.

Para trabalhar com a compreensão, o professor pode elaborar inicialmente o que PIEPHO (1990) chama de tarefas pré-leitura (Aufgaben vor dem Lesen), seguidas de tarefas concomitantes à leitura (Aufgaben während des Lesens) e tarefas pós-leitura (Aufgaben nach dem Lesen). Adaptando um pouco a proposta do autor, apresentamos as seguintes fases: ${ }^{83}$

- Pré-leitura: os alunos vêem de que tipo de texto se trata, observando o todo. Segundo HÄUSSERMANN e PIEPHO (1996: 288), o texto é como uma figura, que vemos primeiro como um todo para depois observarmos os detalhes. LUNEAU (1978: 3), por sua vez, diz que os textos também têm uma função icônica, que se manifesta pela tipografia e pelas ilustrações, por exemplo. Os alunos podem começar assim, tentando então "descobrir" do que o texto vai tratar a partir de sua diagramação, do título, das fotos, legendas, gráficos, etc. Levantam hipóteses sobre o conteúdo e podem fazer outras associações. Também podem dizer que palavras esperam encontrar no texto, e o professor pode até mesmo introduzi-las na língua estrangeira, fazendo um levantamento de vocábulos no quadro, principalmente se houver palavras desconhecidas que são importantes e difíceis de serem inferidas. ${ }^{84}$ Outras tarefas e atividades podem ser propostas nesse momento, especialmente para facilitar a compreensão do que virá e para motivar os alunos. É importante lembrar que o texto é visto neste momento principalmente como portador de informação. Entretanto, deve-

\footnotetext{
${ }^{83}$ HÄUSSERMANN e PIEPHO (1996: 291-319) examinam atividades propostas em alguns livros didáticos de alemão como língua estrangeira, que podem servir como base para a preparação de materiais.

${ }^{84}$ É o que se costuma chamar em alemão de "Vorentlastung", algo como "pré-descarga" (no sentido de "retirar o peso").
} 
se tomar cuidado para que o tempo de previsão não dure mais do que a leitura em si, e, dependendo do que se lê, o conhecimento anterior pode ser até mesmo prejudicial ou dificultar a leitura.

- Concomitante à leitura: os alunos lêem o texto e vêem se suas hipóteses estavam corretas. Dependendo do tipo de compreensão almejado (total, global ou seletiva), as tarefas podem ser variadas, como procurar palavras-chave, completar tabelas, dizer se afirmações são verdadeiras ou falsas e responder questões por extenso. Falaremos mais tarde sobre tipos de exercícios.

- Pós-leitura: os alunos podem dar sua opinião sobre o texto, tentar resumi-lo, comparálo com outros textos já lidos, etc. No caso dos cursos para leitura, é o momento também de introduzir questões lingüísticas. O professor, com o auxílio dos alunos, retira padrões e estruturas do texto, ou palavras do mesmo campo lexical, e desenvolve exercícios para que os alunos aprendam e fixem melhor as estruturas em questão, além de memorizar novos vocábulos. O texto passa a ser então visto preponderantemente como objeto de demonstração de material lingüístico.

A divisão de tarefas também pode ser vista segundo HARDJONO (1990), que o fez, em uma experiência com professores de alemão como língua estrangeira, da seguinte forma:

- Vorbereitungsphase (fase de preparação): escolha do material por parte do professor.

- Einführungsphase (fase de introdução): perguntas prévias sobre o texto, levantamento de hipóteses sobre o conteúdo; corresponderia à tarefa pré-leitura.

- Einstieg in den Text ("entrada" no texto): leitura propriamente dita (direcionada para algum tipo de compreensão mais geral); corresponderia à tarefa concomitante à leitura.

- Rezeptionsphase (fase de recepção): perguntas mais específicas, esclarecimento de dúvidas; corresponderia a uma parte da tarefa pós-leitura.

- Bewusstmachung und Festigungsphase (conscientização e fase de fixação): trabalho com fenômenos sintáticos e unidades lexicais, ou seja, com questões lingüísticas. No curso para leitura, é a fase de introdução dos elementos lingüísticos. 
CICUREL (1991: 43-53), por sua vez, propõe o que chama de "étapes d'une démarche interactive": inicialmente orientar / ativar conhecimentos (o que pode ser feito através de uma conversa sobre experiências prévias, antecipação de cenário, associação de idéias a partir de palavras que poderão aparecer no texto); em seguida observar e tentar captar indícios; depois ler com um objetivo; e, por fim, reagir / relacionar os conhecimentos. A autora também propõe diversas abordagens em relação ao texto, dependendo do nível dos alunos e dos objetivos: segundo a arquitetura discursiva, segundo a busca de elementos co-referenciais, segundo a intenção de comunicação, segundo marcas enunciativas, através de articuladores, com base em citações, com base na progressão temática ou segundo aspectos situacionais (origem do texto, por exemplo).

Assim, baseando-nos nesses autores, dividimos o trabalho em:

- Preparação: escolha do texto e preparação dos exercícios e da aula pelo professor.

- Fase pré-leitura: introdução ao assunto; levantamento de hipóteses através de uso do conhecimento prévio, análise dos aspectos “externos" do texto, etc.

- Fase de leitura: trabalho com um ou mais tipos de compreensão e desenvolvimento de estratégias.

- Fase pós-leitura: trabalho feito a partir da leitura.

- Conscientização e fixação: trabalho com elementos lingüísticos e conscientização de estratégias. Pode ser feita antes ou depois da fase pós-leitura.

É relevante frisar que há tarefas mais ou menos adequadas para cada tipo de compreensão e também para cada gênero e tipo de texto. E é sempre importante que o professor tenha um objetivo em qualquer tarefa que faça, seja ele lingüístico ou de desenvolvimento de estratégias. As tarefas e exercícios devem ser passíveis de alcançar os objetivos a que se propõem (imediatos ou a longo prazo), corresponder ao nível dos alunos, fazer sentido, serem claros e bem organizados e, de preferência, variados.

Também é importante ressaltar aqui que esse é apenas um caminho. Com alunos mais avançados, talvez seja mais interessante seguir outros passos. Entretanto, acreditamos que é importante separar o trabalho em fases e que a divisão acima possa nortear o professor na elaboração do material e da sequiência a ser seguida durante a aula, principalmente em cursos para iniciantes. 
No nosso curso, buscamos a cada aula trabalhar sempre com pelo menos um tipo de compreensão textual, com aspectos lingüísticos e textuais (gramática, vocabulário e fenômenos textuais) e com estratégias. Cada gênero textual foi trabalhado em diversas aulas.

Para finalizar esta parte, acreditamos que é interessante conversar com o aluno sobre como ele lê diversos tipos de texto na língua materna, como essa diversidade e essas habilidades podem ser aplicadas e adaptadas em língua estrangeira, além de desenvolver com ele estratégias e torná-las mais conscientes. Embora no nosso curso tenha se mostrado difícil prever quais estratégias seriam utilizadas em quais momentos, já que elas se alternavam e se complementavam, é importante que haja esse trabalho. Com todos os textos foram trabalhadas várias estratégias, em diversos momentos. Durante a aula elas foram explicitadas pelo professor, e conversou-se também sobre os outros tipos, principalmente as de aprendizagem (com ênfase nas de memorização; a questão do vocabulário se mostrou bastante relevante, como discutiremos mais adiante).

E como exemplo apresentamos aqui um relato sucinto de uma das primeiras aulas do curso por nós ministrado.

Os alunos haviam recebido uma lista com nomes de faculdades, retirada da página da Internet de uma universidade alemã, e aprendido palavras compostas e como desmembrá-las. A aula que aqui apresentamos foi iniciada com a apresentação do texto que se encontra na página seguinte, retirado do site dessa mesma universidade. ${ }^{85}$

Na fase pré-leitura, perguntamos: de onde foi retirada essa página? Por quê? Que tipo de texto parece ser? Que informações vocês esperam encontrar? Os alunos responderam que era uma página da Internet, do site de uma universidade, e que parecia uma lista de disciplinas.

Para a fase de leitura, trabalhamos com a compreensão seletiva, ou seja, de informações específicas. Para isso, entregamos as seguintes questões:

Em que itens você encontra informações sobre:

- a Filosofia da Antigüidade e do início da Idade Média?

- Antropologia Filosófica?

- Filosofia Política?

- Filosofia do Espírito?

85 Retirado de http://webinfo.campus.lmu.de (Wintersemester 2005/2006, Fakultät für Philosophie, Wissenschaftstheorie und Religionswissenschaft), endereço eletrônico acessado pela última vez em maio de 2007. 


\section{$\Xi(1.3)$ Grundstudium: Proseminare und Übungen}

$\exists \quad$ (1.3.1) Theoretische Philosophie

(1.3.1.1) Erkenntnistheorie

(1.3.1.2) Sprachphilosophie

(1.3.1.3) Metaphysik und Ontologie

(1.3.1.4) Philosophie des Geistes

$\exists \quad$ (1.3.2) Praktische Philosophie

(1.3.2.1) Ethik

(1.3.2.2) Handlungstheorie

(1.3.2.3) Politische Philosophie

$\exists \quad$ (1.3.3) Weitere Gebiete der Philosophie

(1.3.3.1) Philosophische Anthropologie

(1.3.3.2) Geschichtsphilosophie

(1.3.3.3) Religionsphilosophie

(1.3.3.4) Ästhetik und Kunstphilosophie

(1.3.3.5) Naturphilosophie

$\exists \quad$ (1.3.4) Geschichte und klassische Texte der Philosophie

(1.3.4.1) Philosophie der Antike und des frühen Mittelalters

(1.3.4.2) Philosophie des späten Mittelalters und der Renaissance

(1.3.4.3) Philosophie der Neuzeit I

(1.3.4.4) Philosophie der Neuzeit II

(1.3.5) Übungen zu Methodik und Didaktik und berufsvorbereitende Veranstaltungen

$\mathrm{Na}$ fase de leitura, queríamos que os alunos utilizassem estratégias de inferência e de atenção seletiva / dirigida, que foi o que ocorreu devido à própria natureza da tarefa. No momento da correção perguntamos aos alunos como chegaram às respostas e ressaltamos as estratégias.

Em seguida passamos à fase de conscientização / fixação: perguntamos onde os adjetivos apareciam em relação aos substantivos e a posição dos complementos. Utilizando as estratégias de indução, transferência e análise, os alunos chegaram à regra, valendo-se também de comparação e de tradução. Como exercício de fixação, os alunos sublinharam os 
adjetivos e formaram sintagmas usando o genitivo: foram dadas as palavras no nominativo e os alunos tinham que combiná-las, como no seguinte exemplo: Philosophie $(f)$ - Geist $(m)$ die Philosophie des Geistes (a Filosofia do Espírito - a segunda palavra está no genitivo). Embora não fosse objetivo do curso a produção em alemão, acreditamos que esse exercício poderia auxiliar na assimilação da estrutura.

$\mathrm{Na}$ fase pós-leitura, perguntamos por quais matérias os alunos se interessariam, quais também eram oferecidas em suas faculdades e quais já haviam cursado.

Para o trabalho na aula é necessário, assim, que o professor dê tarefas prévias para que o aluno compreenda o texto de alguma forma (globalmente ou só informações específicas, por exemplo), para que depois seja feito um trabalho lingüístico. Mas que outras atividades e exercícios podem ser feitos? 


\subsection{Atividades e exercícios}

O objetivo de um curso para leitura é fazer com que os alunos saibam satisfazer suas necessidades e desejos em relação ao conteúdo de um texto, e que, ao final, se tornem leitores independentes. Para isso, eles devem saber estabelecer os objetivos da leitura de um texto e utilizar estratégias adequadas. No nosso caso, esse texto ainda é o veículo para um aprimoramento gradual dos conhecimentos lingüísticos.

É importante, ao escolher um texto, que o professor sempre pense se ele é adequado aos interesses e necessidades do público com que trabalha, em termos de tema e em relação às questões lingüísticas. Após eleito um texto apropriado tendo sido observadas as diversas questões levantadas nos itens anteriores, é necessário que se preparem as atividades e os exercícios. Esses exercícios devem ser claros e permitir que os alunos cheguem aos objetivos previamente estabelecidos. Não devem ir muito além do que o aluno já viu, mas fortalecer e ampliar seus conhecimentos e permitir a prática de estratégias.

No que diz respeito às atividades, elas são aqui entendidas como formas de trabalho mais abertas, tendo como objetivo principal a interação, a motivação, a discussão e a reflexão. ${ }^{86}$ Já os exercícios servem para verificar a compreensão em relação ao conteúdo do texto, para ampliar o conhecimento do idioma e desenvolver estratégias. O que é importante é sempre ter em mente o objetivo de uma atividade ou de um exercício, e buscar os meios de alcançá-lo da melhor forma possível.

Pensemos então nas diversas fases de trabalho com o texto. Durante a fase de préleitura, pode-se examinar a diagramação do texto com os alunos e todos os elementos nãoverbais propriamente ditos: figuras, tabelas, gráficos, etc. A partir deles, do título, da fonte de onde o texto foi retirado e de quem o escreveu, os alunos levantam hipóteses sobre o conteúdo. O professor pode fazer um brainstorming, ou seja, colocar no quadro as palavras que os alunos vão associando ao texto (segundo as hipóteses levantadas) para depois poderem confirmar se suas predições estavam corretas. Outras atividades para iniciar o trabalho, antes mesmo de ser examinado o texto, podem ser feitas através de uma ou mais perguntas já relacionadas ao assunto do texto, através de uma figura ou um trecho de vídeo, por exemplo. Os alunos podem responder abertamente ou trabalhar em duplas ou pequenos grupos. Tudo isso tem o objetivo principal de motivar o aluno e de ativar seus conhecimentos prévios, o que

\footnotetext{
${ }^{86}$ Essa definição de "atividade" é diversa da que propusemos para diferenciar "estratégias" de "atividades". Aqui buscamos diferenciar "atividades" de "exercícios".
} 
pode facilitar a compreensão principalmente quando ainda há pouco conhecimento lingüístico.

$\mathrm{Na}$ fase de leitura, os alunos devem realizar uma tarefa, que pode ser composta de uma ou mais atividades, diretamente ligada ao tipo de compreensão em questão. Se for a compreensão global, o professor pedirá ao aluno que diga do que trata o texto em linhas gerais; se for a compreensão total, este deverá debruçar-se sobre o texto para compreender suas minúcias; se for a compreensão seletiva, o aluno deverá buscar informações previamente requeridas. Para o cumprimento dessa tarefa, o professor passará diretrizes ao grupo, de preferência no quadro, ou alguns exercícios. Ou seja, a tarefa é o que os alunos devem fazer com o texto em um primeiro momento, e pode ser guiada por diretrizes ou por um conjunto de exercícios. Ela pode ser feita individualmente ou em grupos, sempre dependendo dos objetivos pré-estabelecidos. Ao seu término, os alunos comparam os resultados entre si, apresentam-nos para a classe, discutem. É o momento também de esclarecimento de dúvidas, de conscientização de estratégias e de estruturas lingüísticas. O professor poderá então passar para um segundo momento de exercícios, até mesmo mais livre em relação ao texto, para a conscientização das estruturas do idioma e aprendizagem de vocabulário, por exemplo. Essa fase de conscientização / fixação pode ser feita antes ou após a fase pós-leitura.

$\mathrm{Na}$ fase pós-leitura, o professor propõe uma tarefa que vá além do texto, como discutir a respeito do que foi lido, trocar experiências, elaborar um quadro esquemático em grupos, defender uma tese, etc. Pode ser breve, já que não será feita na língua-alvo, mas é importante para que a leitura do texto faça mais sentido, além de aumentar a motivação e a interação.

Mas e os exercícios? Como podem ser? Muitos deles não servem apenas para verificar a compreensão ou para desenvolver estratégias, por exemplo, mas têm esses objetivos entrelaçados. Entretanto, podemos pensar em termos de predominância. Se quisermos atestar principalmente o que foi entendido em relação ao conteúdo de um texto, podemos pensar em:

\section{Perguntas ligadas ao conteúdo}

São perguntas que o professor faz em relação ao conteúdo do texto. Podem ser interessantes pela possibilidade de orientação dos leitores, principalmente quando ainda há poucos conhecimentos lingüísticos, mas trazem a desvantagem de os alunos muitas vezes aprenderem a responder as perguntas sem realmente entender o conteúdo, copiando / traduzindo trechos do texto. Entretanto, podem ser bem utilizadas se adequadamente formuladas e para a busca de informações específicas, por exemplo. 
Como exemplo, uma breve resenha de livro: ${ }^{87}$

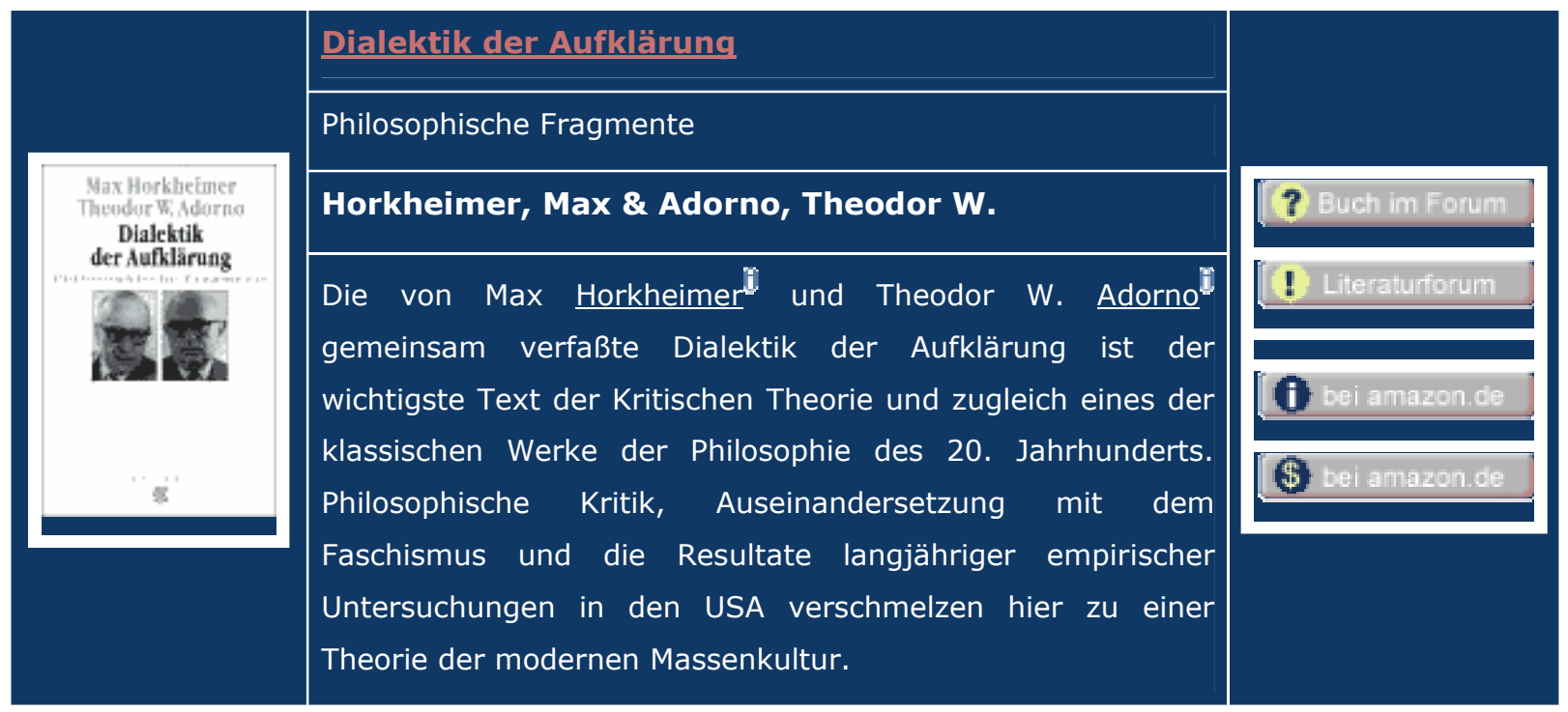

As perguntas feitas foram: a) O livro de Adorno e Horkheimer é tido como o texto mais importante de que área? Além disso, o que mais ele é considerado? b) De que temas o livro parece tratar?

Nesse caso, a orientação dada pelas perguntas ajudou os alunos a encontrar o que foi pedido. Muitos deles localizaram a informação, mas não entenderam algumas palavras. Alguns tentaram "adivinhar" o que as palavras desconhecidas poderiam significar e outros as procuraram no dicionário. Após a compreensão, trabalhou-se com o vocabulário novo.

Embora tal exercício não corresponda a algo que os alunos tenham de fazer na vida real, pois geralmente não têm de responder a perguntas de outras pessoas, e sim a questões que eles mesmos se fazem, ele pode ser interessante no início do aprendizado, quando os conhecimentos lingüísticos são poucos, e para motivar. Além disso, o professor pode formular questões que poderiam corresponder ao que os alunos realmente procurariam, que é o caso da pergunta "b". E ainda, em se tratando de alunos que querem prestar provas de proficiência, aprender a responder perguntas de outros também pode ser importante.

\footnotetext{
87 "Dialética do Esclarecimento. Fragmentos filosóficos. Horkheimer, Max e Adorno, Theodor W. A dialética do esclarecimento, escrita em conjunto por Max Horkheimer e Theodor W. Adorno, é o texto mais importante da Teoria Crítica e ao mesmo tempo uma das obras clássicas da filosofia do século XX. Crítica filosófica, análise do fascismo e os resultados de pesquisas empíricas de muitos anos nos Estados Unidos se fundem aqui em uma teoria da moderna cultura de massas." (tradução minha). Trecho retirado de http://www.philoforum.de/literatur/acn_s/sk1_Grosse+Philosophen/sk2_Adorno/index.html, acessado pela última vez em maio de 2007.
} 


\section{Perguntas abertas}

São perguntas que podem ser feitas a quase qualquer tipo de texto, como "do que trata o texto?" e "qual é o tema?", bem como as respostas aos pronomes interrogativos: quem, o quê, quando, onde, como, por quê. Têm a vantagem de ser um exercício ativo, mas corre-se o risco de receber respostas evasivas ou cópia / tradução de trechos do texto, dependendo de como ele está estruturado.

Utilizando o mesmo texto do item acima - e aproveitando para mostrar que um mesmo texto pode ser trabalhado de diversas formas -, as perguntas abertas poderiam ser: (a) Que tipo de texto é esse? Por quê? (b) Do que trata? Para responder a última pergunta, os alunos não poderiam copiar / traduzir trechos do texto, mas achar os pontos principais.

Perguntas abertas são, assim, perguntas bastante úteis, pois podem ser utilizadas para qualquer tipo de texto; além disso, são perguntas que os alunos poderiam realmente fazer a si mesmos em situações reais de leitura, em que ainda não conhecem o conteúdo do texto.

\section{Verdadeiro ou falso}

O professor formula uma oração e o aluno deve dizer se ela é verdadeira ou falsa de acordo com o texto. A desvantagem é que o aluno tem $50 \%$ de chance de acertar sem ter compreendido a oração ou o trecho do texto em questão.

Como exemplo, temos um trecho retirado do prefácio da obra "Einführung in die Philosophie", de Karl Jaspers: ${ }^{88}$

Für einen wissenschaftsgläubigen Menschen ist das Schlimmste, dass die Philosophie gar keine allgemeingültigen Ergebnisse hat, etwas, das man wissen und damit besitzen kann. Während die Wissenschaften auf ihren Gebieten zwingend gewisse und allgemein anerkannte Erkenntnisse gewonnen haben, hat die Philosophie dies trotz der Bemühungen der Jahrtausende nicht erreicht. (...) Das philosophische Denken hat auch nicht, wie die Wissenschaften, den Charakter eines Fortschrittsprozesses. Wir sind gewiss viel weiter als Hippokrates, der griechische Arzt. Wir dürfen kaum sagen, dass wir weiter seien als Plato.

\footnotetext{
${ }^{88}$ JASPERS, Karl. Einführung in die Philosophie. München / Zürich: Piper, 1986.
} 
Nur im Material wissenschaftlicher Erkenntnisse, die er benutzt, sind wir weiter. Im Philosophieren selbst nicht. ${ }^{89}$

Leia as afirmações e diga se são verdadeiras ou falsas, de acordo com o trecho acima:

a. Pessoas que acreditam na ciência não acreditam na filosofia. (f)

b. Segundo o autor, somente a ciência alcançou resultados universalmente tidos como certos; a filosofia não. (v)

c. Segundo o autor, estamos mais adiantados do que Hipócrates e do que Platão. (f)

O exercício de verdadeiro ou falso pode ser interessante se não trouxer simplesmente frases copiadas do texto, mas paráfrases ou reformulações, corretas ou não, para que os alunos tenham que analisar trechos e realmente compreendê-los para responder. Pode ser elaborado na língua-alvo ou na língua materna, dependendo do nível do grupo e dos objetivos.

\section{Múltipla escolha}

O professor formula uma questão ou uma oração em aberto e dá algumas possibilidades de resposta ao aluno (geralmente quatro ou cinco). A desvantagem é que o aluno já recebe respostas prontas, sem ter que formular nada, mas pode ser interessante para estratégias. E, dependendo de como as alternativas são formuladas, podem mostrar uma compreensão bem precisa, como pode ser o caso do exercício de verdadeiro e falso.

Como exemplo, utilizamos um trecho da obra "Die Traumdeutung", de Sigmund Freud..$^{90}$ Após ter sido feita a leitura da parte inicial, em que Freud diz que num primeiro momento apresentará o que se sabe a respeito da interpretação dos sonhos desde o princípio dos tempos, os alunos lêem o seguinte trecho:

\footnotetext{
${ }^{89}$ Para quem acredita na ciência, o que a filosofia tem de pior é não atingir conclusões geralmente válidas, que se possam aprender e portanto possuir. Enquanto as ciências alcançaram nos seus domínios resultados necessariamente certos e geralmente reconhecidos como tal, a filosofia não logrou a mesma evidência após milenários esforços. (...) o pensamento filosófico não tem, como as ciências, o caráter de um processo progressivo. Estamos, decerto, mais adiantados do que Hipócrates, o médico grego. Mas já não podemos dizer que estejamos mais adiantados do que Platão, excetuando apenas o conjunto material de conhecimentos científicos que teve ao seu dispor. No filosofar propriamente dito, não." JASPERS, Karl. Introdução à filosofia. Trad. de Manuela Pinto dos Santos. Lisboa: Guimarães Editores, 1998.

${ }^{90}$ FREUD, Sigmund. Die Traumdeutung. Frankfurt am Main: Fischer, 1977. p.13-15.
} 


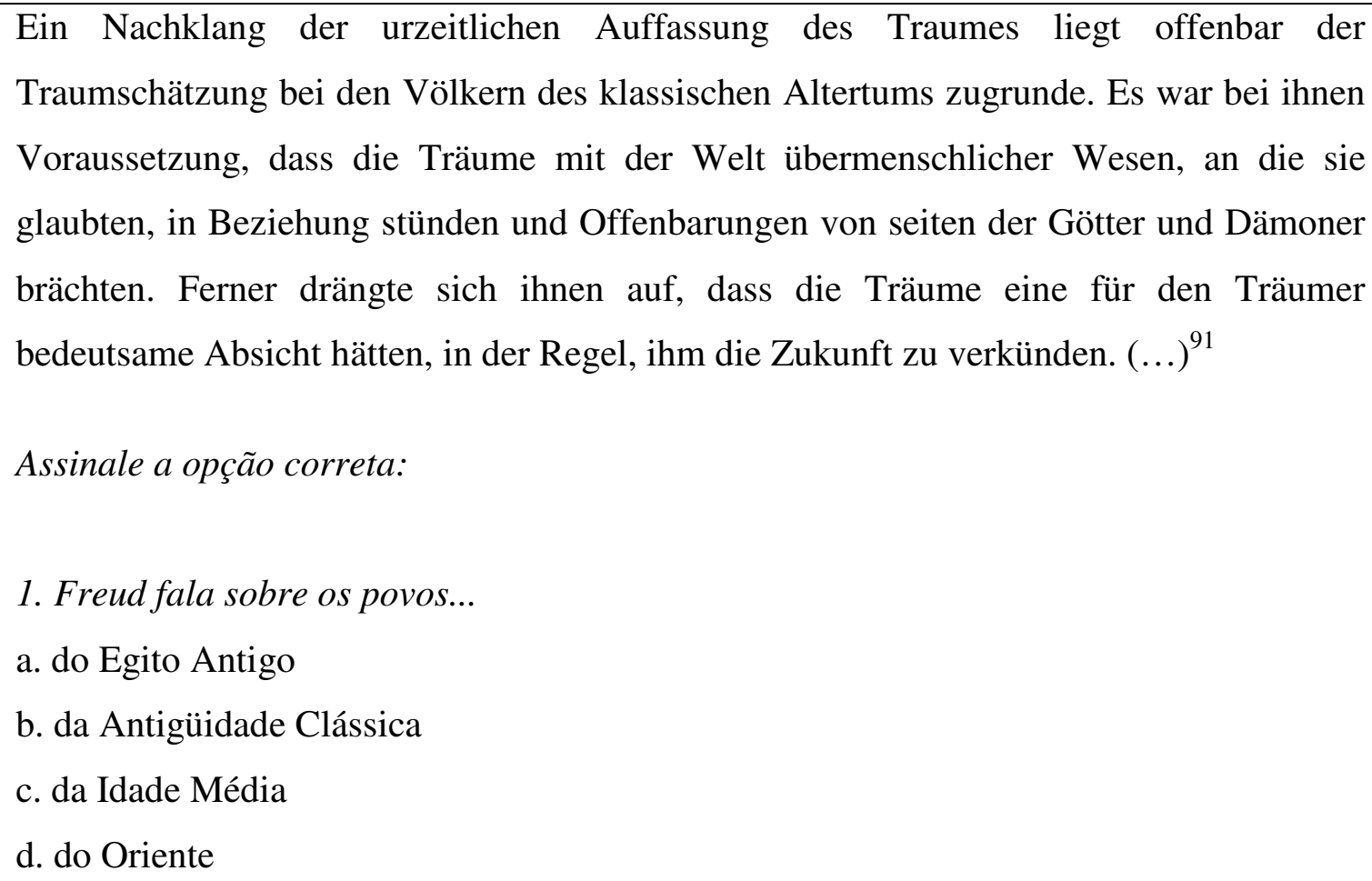

2. Esses povos acreditavam que...

a. os sonhos estavam relacionados com os acontecimentos do mundo.

b. os sonhadores tinham contato direto com deuses e demônios.

c. os sonhos eram revelações de deuses e demônios.

d. o mundo sobrenatural os perseguia através dos sonhos.

\section{Para esses povos, qual era a intenção dos sonhos?}

a. predizer o futuro.

b. castigá-los.

c. ensinar-lhes algo.

d. colocá-los em contato com o mundo sobrenatural.

Corretas: 1b, 2c, 3a

\footnotetext{
91 "En las ideas que los pueblos de la Antigüedad clásica tenían sobre el sueño resuena manifiestamente un eco de la concepción primitiva. Suponían que los sueños estaban en relación con el mundo de seres sobrehumanos en que ellos creían, y que traían revelaciones de los dioses y los demonios. Además, estaban convencidos de que contenían un mensaje importante para quien los soñaba: por regla general le anunciaban el porvenir. (...)" FREUD, Sigmund. "La interpretación de los sueños". In: Obras completas, vol. IV e V. Tradução de José Luís Etcheverry. Buenos Aires: Amorrortu, 1996. p.30.
} 
O exercício de múltipla escolha, assim como o de perguntas ligadas ao conteúdo e o de verdadeiro ou falso, pode ser uma orientação para o aluno, principalmente se ele não dispõe ainda de muitos conhecimentos lingüísticos. As alternativas formuladas devem ser todas plausíveis, para que os alunos realmente leiam o texto para responder a questão, e não se valham apenas do conhecimento que já possuem.

Cloze

O cloze é um texto com lacunas em que se deve inscrever a palavra que está faltando. Essa palavra, porém, deve ser importante para o texto e possível de ser adivinhada. Sugere-se que não se apaguem muitas palavras para não aumentar muito a dificuldade e para que não se perca o objetivo do exercício. Há o cloze clássico, já descrito, o de múltipla escolha (em que o aluno tem, em vez de uma lacuna, algumas opções de resposta) e o "cloze ao contrário", em que palavras estranhas ao texto são mescladas a ele e devem ser eliminadas. Além de testar a compreensão, diversas estratégias podem ser aplicadas nesse exercício.

O cloze clássico, quando feito na língua estrangeira, parece ser mais adequado a alunos avançados ou que estejam fazendo cursos também voltados para a produção lingüística. No caso de um curso para leitura como o que aqui descrevemos, podem ser deixadas as opções para que se completem as lacunas (cloze de múltipla escolha).

Usaremos o mesmo exemplo para mostrarmos as diferenças entre os tipos de cloze. $\mathrm{O}$ texto é uma pequena biografia de Kierkegaard retirada da Internet, que aparece na resenha de seu livro "Entweder - Oder". 92

Complete as lacunas com as palavras que faltam:

Sören Kierkegaard wurde 1813 in Kopenhagen und lebte nach dem der Theologie und Philosophie vom väterlichen Erbe. Mit seinen berühmten gilt er als der Begründer der Existenz-Philosophie. 1855 er mutmaßlich an den Spätfolgen einer syphilitischen

(Respostas: geboren - Studium - Werken - starb - Erkrankung )

\footnotetext{
92 A tradução com as lacunas já preenchidas seria: "Sören Kierkegaard nasceu em 1813 em Copenhague e viveu, após os estudos de Filosofia e Teologia, da herança paterna. Com suas famosas obras, ele é considerado o fundador da Filosofia Existencial. Morreu em 1855, supostamente devido às conseqüências de uma sífilis." O trecho original foi acessado pela última vez no mês de maio de 2007 no endereço eletrônico http://www.philoforum.de/literatur/acn_s/sk1_Grosse+Philosophen/sk2_Kierkegaard/index.html.
} 
As respostas dadas são as palavras que foram retiradas do texto, mas sinônimos também poderiam ser aceitos. WESTHOFF (1997: 117 em diante) nos lembra que a palavra retirada do texto deve ser possível de ser adivinhada e deve ser importante. Segundo o mesmo autor, a aprendizagem é tanto mais efetiva quanto maior for o número de estratégias que o aluno tiver de utilizar para descobrir qual é a palavra, e também se a "pista" para sua descoberta vier depois da palavra, e não antes.

O mesmo exercício poderia ser feito dando-se inicialmente quais as palavras a serem inseridas:

Complete as lacunas com as seguintes palavras: Begründer - Erkrankung - gilt - lebte Philosophie - Theologie - starb - wurde.

Sören Kierkegaard

Studium der 1813 in Kopenhagen geboren und und er als der vom väterlichen Erbe. Mit seinen der Existenz-Philosophie. 1855 er mutmaßlich an den Spätfolgen einer syphilitischen

(Respostas: wurde - lebte - Philosophie / Theologie - Theologie / Philosophie - gilt Begründer - starb - Erkrankung)

Com esse exercício também podem ser trabalhados determinados aspectos gramaticais, como completar as lacunas somente com verbos. Também podem ser dados verbos no infinitivo para que se completem os espaços em branco com um determinado tempo verbal ou com o tempo verbal adequado, sendo que nesses casos se trabalha tanto a compreensão do trecho quanto a parte lingüística. A produção dos alunos, nesse caso, serviria para uma melhor compreensão e fixação do conteúdo.

Já como exemplo de um cloze de múltipla escolha, teríamos:

Sublinhe a palavra em itálico que é adequada ao trecho:

Sören Kierkegaard wurde 1813 in Kopenhagen geboren / gestorben / gegangen und arbeitete / lebte / kaufte nach dem Studium der Theologie und Philosophie vom väterlichen Erbe. Mit seinen berühmten Werken / Leben / Wissenschaft gilt er als der Student / Begründer / Freund der Existenz-Philosophie. 1855 stirbt / starb / gestorben er mutmaßlich an den Spätfolgen einer syphilitischen Krankenhaus / Erkrankung / krank.

(Respostas: geboren - lebte - Werken - Begründer - starb - Erkrankung) 
Nesse caso as palavras em itálico também podem ser o mesmo verbo em tempos verbais diferentes para que se escolha o tempo adequado, ou palavras semelhantes ou com o mesmo radical, por exemplo. Depende daquilo com que o professor quer trabalhar.

Como exemplo de "cloze ao contrário", teríamos:

Assinale as palavras estranhas ao texto e que devem ser retiradas:

Sören Kierkegaard wurde war 1813 in Kopenhagen geboren und lebte nach der dem Studium der Theologie und Philosophie vom väterlichen Erbe. Ohne mit seinen berühmten Werken gilt er als arbeiten der Begründer der Existenz-Philosophie. 1855 starb er mutmaßlich an den Spätfolgen einer syphilitischen krank Erkrankung.

(Resposta: eliminar as palavras: linha 1: war - der / linha 2: ohne / linha 3: arbeiten / linha 4: krank)

\section{Correspondência}

Exercícios de correspondência podem ser de vários tipos, como ligar duas colunas com trechos do texto, ligar sinônimos ou antônimos, associar fragmentos do texto com figuras que os representam, etc.

No exemplo a seguir, os alunos deveriam relacionar frases célebres com seus autores. Foi um exercício feito nas primeiras semanas de curso, e contamos com o conhecimento prévio dos alunos para "adivinhar" palavras, já que deveriam conhecer algumas das frases em português e também reconhecer cognatos.

Relacione a frase com seu autor:

(a) Das Wasser ist das Grundprinzip der Welt.

( ) Descartes

(b) Der Mensch ist das Maß aller Dinge.

( ) Marx

(c) Gott ist tot.

( ) Nietzsche

(d) Die Religion ist das Opium des Volkes.

( ) Protagoras

(e) Ich denke, also bin ich.

( ) Sokrates

(f) Ich weiß, dass ich nichts weiß.

( ) Thales von Milet

Respostas: e, d, c, b, f, a 


\section{Paráfrase}

Exercício que pode fazer parte das perguntas abertas, consiste em reformular com suas próprias palavras um determinado trecho do texto. Em outras palavras, trata-se de explicar um determinado trecho, o que, no caso de cursos para leitura, é geralmente feito em língua materna, mas também poderia ser feito em língua estrangeira, dependendo do tipo de curso e se quisermos dar ênfase à questão gramatical.

Por exemplo, apresentamos a seguinte definição: ${ }^{93}$

Aufklärung, europäische Geistesbewegung vor allem des 18. Jh. Die Aufklärung sah in der Vernunft das eigentliche Wesen des Menschen; sie suchte die Kultur von kirchlicher Bevormundung und Aberglauben zu befreien, erstrebte Toleranz und glaubte an den steten Fortschritt der Menschheit durch Gestaltung des Lebens nach vernünftigen Grundsätzen und durch wissenschaftliche Forschung. Politisch führte die Aufklärung zum aufgeklärten Absolutismus und bereitete die Französische Revolution vor. ${ }^{94}$

Os alunos devem ler o trecho e dizer a mesma coisa com suas palavras. Para isso, podem levantar palavras-chave que usarão na resposta, no que podem ser auxiliados pelo professor juntamente com o resto da classe. Deve-se sempre tomar cuidado para que a paráfrase seja feita de acordo com o texto, e não só conforme o que o aluno já sabe (e que ele poderia fazer sem ter lido o texto).

Um aluno poderia, à guisa de exemplo, dar como resposta: "O Esclarecimento (ou Aufklärung) é um movimento intelectual que buscava a razão e que acreditava que os homens só poderiam progredir através dela, sem a igreja; foi esse movimento que levou ao Absolutismo Esclarecido e à Revolução Francesa.”

\footnotetext{
${ }_{93}^{93}$ Retirada de Lexikon der Allgemeinbildung (2000), Duden, páginas 297-298.

94 "Esclarecimento (Aufklärung): movimento intelectual europeu principalmente do século XVIII. O Esclarecimento via na razão a verdadeira essência do homem; buscava libertar a cultura da tutoria da igreja e da superstição, almejava tolerância e acreditava no progresso constante da humanidade através da configuração da vida segundo princípios racionais e através da pesquisa científica. Politicamente o Esclarecimento levou ao Absolutismo Esclarecido e preparou a Revolução Francesa.” (tradução minha)
} 


\section{Comentários}

Exercício que pode estar incluído nas perguntas abertas, consiste em comentar um determinado trecho e pode incluir opiniões pessoais a respeito.

Como exemplo, apresentamos um trecho de um texto, trabalhado com os alunos durante o segundo curso por nós ministrado, que não era estritamente da área de Ciências Sociais, mas que despertou o interesse da classe: foi um artigo da Revista Stern, publicado na edição de agosto de 2005, sobre as relações afetivas e amorosas no Brasil, parte de uma série de artigos intitulada "So liebt die Welt" ("Assim ama o mundo"). Em um trecho dessa reportagem, havia o seguinte item:

\section{Wer klärt auf?}

Für Eltern ist das Thema Sex meist tabu. Auch in der Schule wurde Sexualkunde lange nicht unterrichtet, aber das ändert sich. Oft werden Kinder durch Filme, Zeitschriften und Fernsehen aufgeklärt. Viele reden mit ihren Freunden darüber. $^{95}$

Após lerem esse trecho, os alunos fizeram diversos comentários sobre como se dá o esclarecimento sexual no Brasil: como era antes, como é hoje, e se concordavam ou não com a reportagem.

Síntese

Exercício que também pode fazer parte das perguntas abertas, consiste em resumir o texto ou alguns trechos dele com suas próprias palavras.

Como exemplo, podemos retomar a definição de Aufklärung, apresentada como exercício de paráfrase, e pedir aos alunos que não digam com suas próprias palavras o que o trecho quis dizer, mas que façam um resumo do principal: se tivessem que dizer tudo em uma única oração, como o fariam? Como seria essa oração? Isso seria um exemplo de exercício de síntese.

\footnotetext{
95 "Quem esclarece / orienta? Para os pais o tema sexo é em geral tabu. Também na escola por muito tempo não se ensinava Educação Sexual, mas isso está mudando. As crianças são freqüentemente esclarecidas / orientadas através de filmes, revistas e da televisão. Muitos conversam com seus amigos a respeito." (tradução minha)
} 
Tabela

Monta-se uma tabela com itens que os alunos devem procurar no texto. Útil principalmente para a busca de informações específicas.

No estágio inicial do nosso curso, trabalhamos com uma lista de referências bibliográficas e pedimos que os alunos completassem uma tabela a respeito dos livros: ${ }^{96}$

Complete a tabela sobre os livros: ${ }^{97}$

\begin{tabular}{|c|c|c|c|c|}
\hline Título & Autor & Editora & Cidade & $\begin{array}{c}\text { Ano de } \\
\text { publicação }\end{array}$ \\
\hline $\begin{array}{c}\text { Gesellschaftstheorie } \\
\text { und Kulturkritik } \\
\text { (Teoria da Sociedade e } \\
\text { Crítica da Cultura) }\end{array}$ & Theodor W. Adorno & Suhrkamp & Frankfurt & 1975 \\
\hline $\begin{array}{l}\text { Summe der Theologie } \\
\text { (Sumas teológicas) }\end{array}$ & $\begin{array}{l}\text { Thomas v. Aquin } \\
\text { (Tomás de Aquino) }\end{array}$ & Suhrkamp & $?$ & 1985 \\
\hline $\begin{array}{l}\text { Metaphysik } \\
\text { (Metafísica) }\end{array}$ & Aristóteles & Felix Meiner & Hamburg & 1989 \\
\hline $\begin{array}{l}\text { Bekenntnisse } \\
\text { (Confissões) }\end{array}$ & $\begin{array}{l}\text { Aurelius Augustinus } \\
\text { (Agostinho) }\end{array}$ & Suhrkamp & Frankfurt & 1987 \\
\hline $\begin{array}{c}\text { Die Prinzipien der } \\
\text { Philosophie (Os } \\
\text { Princípios da } \\
\text { Filosofia) }\end{array}$ & René Descartes & Felix Meiner & Hamburg & 2005 \\
\hline $\begin{array}{c}\text { Die Traumdeutung } \\
\text { (A interpretação dos } \\
\text { sonhos) }\end{array}$ & Sigmund Freud & Fischer & $?$ & 2005 \\
\hline
\end{tabular}

Nesse exercício especificamente, perguntamos aos alunos que livros eles já conheciam. Muitos identificaram as palavras alemãs mesmo sem conhecê-las porque conheciam o título em português. Sendo assim, o professor pode pedir que a tabela seja completada na língua estudada ou em português (quando possível), ou em ambas as línguas.

\footnotetext{
${ }^{96} \mathrm{O}$ professor também poderia levar diversos livros para a sala de aula e pedir que os alunos procurassem neles as informações requeridas na tabela.

97 As informações marcadas com “?” não foram encontradas pelos alunos nos livros.
} 
Isto é, os alunos podem colocar os títulos em português, se já os conhecerem, ou traduzirem literalmente e depois conversar a respeito.

\section{Palavras-chave}

Os alunos devem retirar do trecho palavras-chave que o sintetizem. Novamente retomando a definição de Aufklärung, sobre a qual tratamos no item paráfrase e no item síntese, podemos pedir aos alunos que digam quais palavras não poderiam faltar para a explicação de tal definição. Os alunos certamente diriam "Vernunft" (razão) e poderiam discutir a respeito das outras até escolherem as principais. $\mathrm{O}$ professor poderia dar um limite de palavras (5, por exemplo) para propiciar a discussão.

\section{Diagrama}

Os alunos elaboram um diagrama do texto, resumindo-o de forma gráfica, com quadros e flechas, por exemplo.

Diagramas de textos argumentativos podem ser interessantes, mas são difíceis para alunos iniciantes. Uma forma de diagrama comum é a "linha do tempo" quando se trata de biografias. Como exemplo, propomos um exercício, para alunos iniciantes, após a leitura de um trecho de uma biografia de Habermas: ${ }^{98}$

Jürgen Habermas wurde am 18. Juni 1929 in Düsseldorf geboren. Nach dem Abitur in Gummersbach studierte er von 1949 bis 1954 an den Universitäten Göttingen, Zürich und Bonn Philosophie, Geschichte, Psychologie, Deutsche Literatur, Ökonomie unter anderem bei Erich Rothacker und Oskar Becker und promovierte 1954. Seine akademische Karriere begann Habermas 1961 als außerordentlicher Professor für Philosophie und Soziologie an der Universität Frankfurt am Main - als Nachfolger von Max Horkheimer. Habermas gilt als der prägendste deutsche Philosoph der Gegenwart, der vor allem in den 1970er Jahren innovative Diskussionen in den Sozialwissenschaften förderte. (...) 1971 wechselte Habermas als Direktor an das Max-Planck-Institut zur Erforschung der Lebensbedingungen der wissenschaftlich-technischen Welt in Starnberg. 1980 wurde er Direktor des Starnberger Max-Planck-Instituts für Sozialwissenschaften (...).

98 Trecho retirado do endereço eletrônico http://www.boersenverein.de/de/96671?pid=97208, acessado pela última vez em maio de 2007. 
Faça um diagrama / uma linha do tempo da vida de Habermas:

nasceu em Düsseldorf (1929) - estudou Filosofia, História, Psicologia, Literatura Alemã e Economia em várias universidades - começou carreira acadêmica em Frankfurt (sucessor de Horkheimer) - foi diretor do Instituto Max Planck (...)

O diagrama (nesse caso a linha do tempo) pode ser feito em língua materna ou em língua estrangeira, dependendo do nível dos alunos e dos objetivos do exercício. Os dados presentes podem ser especificados pelo professor ou pelos alunos, por isso pode haver variações. Acima apresentamos uma possibilidade.

\section{Lacunas}

Os alunos preenchem um texto em lacunas de acordo com o que leram. Utilizando o mesmo trecho da biografia de Habermas de que tratamos no item anterior, teríamos, por exemplo:

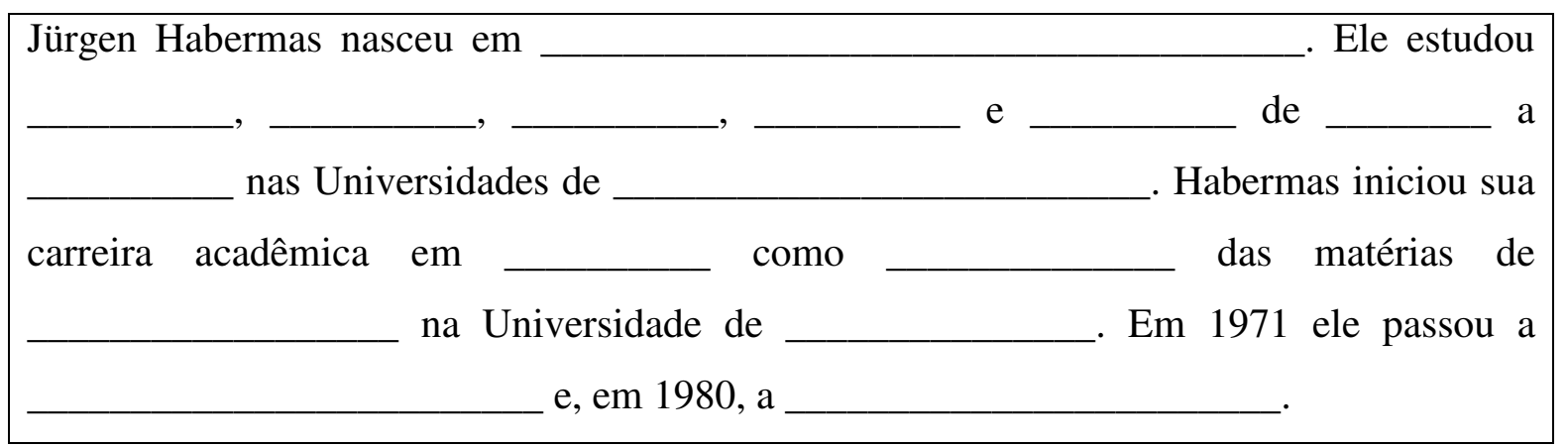

É importante ressaltar que esses exercícios devem ser feitos em geral em língua materna, já que os cursos para leitura não costumam ter como objetivo a produção por parte do aluno. Principalmente se o aluno tiver que dar uma resposta, o importante é que ele tenha compreendido o texto, e não que saiba se expressar corretamente na língua-alvo. Além disso, vale lembrar que vários desses exercícios podem ser usados para todos os tipos de compreensão, dependendo da forma como são elaborados.

Além dos exercícios mencionados, há aqueles que podem ser feitos oralmente, como dar a opinião a respeito do texto e dizer o que entendeu de um determinado trecho ou de todo o conteúdo. Isso se dá geralmente de maneira espontânea, durante as discussões e correções, e 
pode ser um termômetro para o professor em relação à classe. Tais exercícios também podem ser feitos na fase pós-leitura.

Também devem ser feitos exercícios específicos para a prática de estratégias. É importante que essas estratégias sejam aplicadas e ressaltadas, pois se aprende melhor fazendo algo e tendo consciência do que se faz (WESTHOFF 1997: 80). Assim, os alunos devem, após qualquer atividade ou exercício, refletir em conjunto sobre como chegaram a determinadas respostas ou conclusões, para que haja conscientização das estratégias envolvidas. ${ }^{99}$ Muitos alunos podem chegar a uma resposta correta por acaso ou não saber aplicar uma determinada estratégia em casos semelhantes por não tê-la clara para si.

Agora vamos expor alguns exercícios pensando nas estratégias que queremos desenvolver de acordo com os quadros anteriormente apresentados e também no trabalho com a língua propriamente dito:

Esclarecimento / verificação: pedir / procurar um exemplo de como usar uma palavra ou expressão; consultar uma gramática, dicionário, textos de apoio, traduções, etc.

Durante a fase de compreensão, os alunos podem levantar palavras que lhes pareçam importantes no texto e procurar no dicionário aquelas que são desconhecidas. Depois podem dizer como fizeram isso e quais foram as dificuldades. É necessário ressaltar a importância de o professor ensinar os alunos a trabalhar com obras de referência.

Como exemplo, retomaremos o trecho do artigo da revista Stern mencionado no item comentários. Os alunos lêem o trecho e tentam construir um sentido, inferindo o significado das palavras novas. Pode ser, entretanto, que alguns eles não consigam inferir, como aconteceu no nosso curso com, por exemplo, as palavras "unterrichtet" (particípio passado de lecionar, ensinar) e "ändern" (mudar), embora tenham surgido bons "palpites”. Foi, então, a hora de consultar o dicionário ou perguntar para o professor.

\section{Wer klärt auf?}

Für Eltern ist das Thema Sex meist Tabu. Auch in der Schule wurde Sexualkunde lange nicht unterrichtet, aber das ändert sich. Oft werden Kinder durch Filme, Zeitschriften und Fernsehen aufgeklärt. Viele reden mit ihren Freunden darüber.

\footnotetext{
${ }^{99}$ É o que WESTHOFF (1997: 80) chama de "verbale Phase" (fase verbal) ou simplesmente "verbalisieren" (verbalizar).
} 
Durante a fase de trabalho com a língua, ou seja, nos exercícios, o professor pode pedir que os alunos procurem sinônimos ou antônimos de determinadas palavras, algumas possibilidades de tradução, ou trabalhar com outras questões gramaticais. Ainda nos valendo do trecho novamente apresentado, o professor poderia pedir que os alunos procurassem o singular das palavras "Kinder", "Zeitschriften" e "Freunde(n)", ou o infinitivo dos verbos que aparecem no trecho; ou, ainda, que passassem as orações que se encontram na voz passiva (que são duas) para a voz ativa.

Inferência: tentar descobrir o significado de uma palavra pelo contexto ou por tentativas.

Durante a fase de compreensão do texto, os alunos devem tentar entender palavras desconhecidas pelo contexto e buscar dar-lhes um significado aproximado. Foi o que os alunos fizeram, retomando o trecho da revista Stern comentado no item anterior, com as palavras "unterrichtet" e "ändern", embora tenham chegado a resultados plausíveis, mas não exatos. Já a palavra "meist" foi corretamente inferida por um aluno como "geralmente"/ "na maioria das vezes", porque ele partiu da palavra inglesa "most". A palavra "Fernsehen" (televisão) foi corretamente inferida pelo contexto, já que no trecho já haviam aparecido as palavras "Filme" (filmes) e "Zeitschriften" (revistas), o que dava a idéia de meios de comunicação; além do contexto, nesse caso, a análise da palavra auxiliou na correta interpretação, já que o vocábulo "Fernsehen" continha o verbo já conhecido "sehen" ("ver"), a partir do que os alunos chegaram ao substantivo "televisão". Além disso, sabiam que se tratava de um substantivo pelo fato de tal palavra estar escrita com letra maiúscula. ${ }^{100}$

Durante a fase de trabalho com a língua, os alunos podem trabalhar com a formação de palavras, tentando desmembrá-las, e construir novas palavras a partir de um radical ou de uma palavra primitiva. Também podem tentar traduzir palavras com o mesmo radical e de classes gramaticais diferentes.

Exemplo: ao trabalharmos inicialmente com listas de aulas de uma universidade alemã $^{101}$, apareceram várias palavras compostas, que os alunos desmembraram para tentar compreender. Apresentamos a página inicial:

\footnotetext{
${ }^{100}$ Todos os substantivos são escritos em alemão com letra inicial maiúscula.

${ }^{101}$ Retirado de http://webinfo.campus.lmu.de, endereço eletrônico acessado pela última vez em maio de 2007.
} 
Wintersemester 2005/2006

国 Fakultätsübergreifende Veranstaltungen

It Katholisch-Theologische Fakultät

(t) Evangelisch-Theologische Fakultät

田

国 $\underline{\text { Fakultät für Betriebswirtschaft }}$

$\boxplus$ Volkswirtschaftliche Fakultät

国 Medizinische Fakultät

田 $\underline{\text { Tierärztliche Fakultät }}$

国 Fakultät für Geschichts- und Kunstwissenschaften

¥ Fakultät für Philosophie, Wissenschaftstheorie und Religionswissenschaft

国 Fakultät für Psychologie und Pädagogik

田 Fakultät für Kulturwissenschaften

国 Fakultät für Sprach- und Literaturwissenschaften

ঊ Sozialwissenschaftliche Fakultät

田 Fakultät für Mathematik, Informatik und Statistik

[t] Fakultät für Physik

9 Fakultät für Chemie und Pharmazie

๒ Fakultät für Biologie

田 Fakultät für Geowissenschaften

As palavras compostas foram inicialmente levantadas pelos alunos após um exercício de compreensão proposto:

Em qual item você deve clicar se quiser estudar:

- Religião?

- Cultura?

- Literatura?

- Geologia? 
Após a análise das palavras e da leitura de um índice de disciplinas da Faculdade de Filosofia, foi apresentada, para o trabalho com a língua, uma lista de palavras para os alunos desmembrarem.Algumas dessas palavras foram:

$$
\begin{aligned}
& \text { Einführungstext - Einführung / s / text } \\
& \text { Existenzphilosophie - Existenz / philosophie } \\
& \text { Inhaltsverzeichnis - Inhalt / s / verzeichnis } \\
& \text { Grammatiktheorie - Grammatik / theorie } \\
& \text { Hochschulstudent - Hoch / schul(e) / student } \\
& \text { Kognitionspsychologie - Kognition / s / psychologie }
\end{aligned}
$$

Em seguida pediu-se aos alunos que tentassem chegar a uma regra e que montassem outras palavras.

Indução: tentar depreender uma regra através de exemplos.

Durante a fase de compreensão do texto, os alunos devem se valer do contexto para entender determinadas estruturas lingüísticas que ainda são desconhecidas, buscando sempre o sentido.

Ao trabalharmos com biografias, os alunos se basearam principalmente em números (como datas) e nomes próprios para entender do que se tratava nos diversos trechos. Como exemplo, apresentamos uma breve biografia de Kant, retirada da Internet: ${ }^{102}$

\footnotetext{
102 Trecho retirado do endereço eletrônico http://gutenberg.spiegel.de/autoren/kant.htm , acessado pela última vez em maio de 2007.
} 


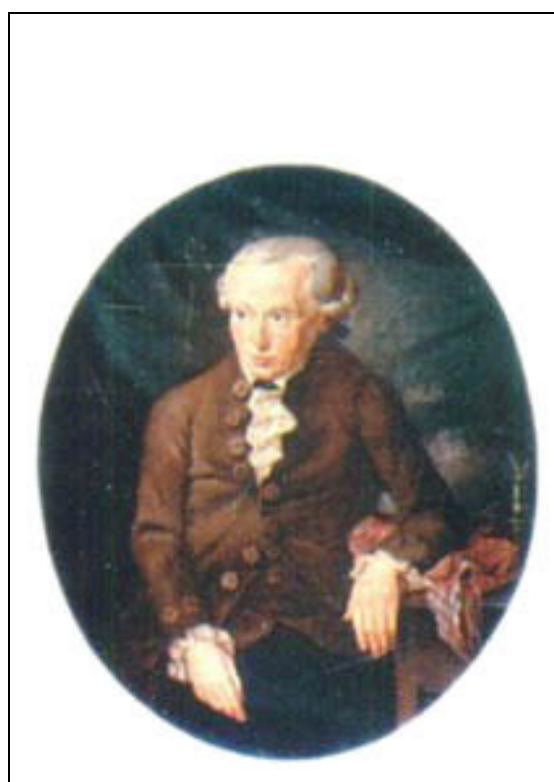

\section{Immanuel Kant}

Geboren am 22.4.1724 in Königsberg; gestorben am 12.2.1804 in Königsberg.

Als viertes von neun Kindern eines Riemermeisters besuchte Kant von 1732 bis 1740 das streng pietistische Gymnasium Fridericianum in Königsberg. 1740-46 studierte er an der Königsberger Universität; danach unterrichtete er als Hauslehrer (Hofmeister) bei verschiedenen Familien in Ostpreußen. 1754 kehrte er nach Königsberg zurück, wurde zum Magister promoviert, habilitierte sich und nahm eine thematisch sehr breite Vorlesungstätigkeit auf: Logik, Metaphysik, Moralphilosophie, Mathematik, Physik, Geographie (die er als akademisches Lehrfach einführte), später noch Anthropologie, Pädagogik, Naturrecht, natürliche Theologie, gelegentlich auch Festungsbau. Seine ungesicherte wirtschaftliche Lage besserte sich aber erst 1770, als ihm endlich die Professur für Logik und Metaphysik übertragen wurde; Rufe nach Erlangen, Jena und Halle lehnte er ab. 1796 stellte er seine Vorlesungen ein, 1801 zog er sich aus den akademischen Ämtern zurück.

Os alunos partiram das datas para entender que 1724 e 1804 seriam os anos de nascimento e de morte do autor. Logo no início, viram a palavra "viertes" e a relacionaram ao número quatro ("vier”); também entenderam "neun Kinder(n)" (nove crianças) e chegaram à conclusão de que Immanuel Kant havia sido o quarto de nove filhos. Sabendo que dados uma biografia geralmente traz, os alunos foram conseguindo compreender as informações principais. Já durante a fase de trabalho com a língua, em que os alunos devem tentar retirar do texto, com a ajuda do professor, exemplos de estruturas semelhantes e buscar o que elas têm em comum e a qual regra podem chegar, os alunos analisaram os verbos: localizaram-nos no texto, mesmo não entendendo o significado de todos, e notaram que vários deles tinham a terminação "-te" (como em "studierte", "unterrichtete", "besserte", "lehnte... ab", "stellte... ein”). Também notaram que várias outras palavras pareciam ser verbos, mas não tinham tal terminação: concluíram, com o auxílio do professor, que se tratava de verbos regulares e de verbos irregulares, chegando, assim, a uma regra. 
Como exercício lingüístico poderia ser proposto um exercício de cloze sobre outro autor por quem o grupo se interessasse, ou então pedir aos alunos que passassem um texto com verbos no presente para o passado (lembrando que exercícios de produção servem para a conscientização das formas e para auxiliar na memorização, e não porque os alunos precisarão necessariamente produzir corretamente na língua estudada).

Transferência: usar informação lingüística conhecida para facilitar a compreensão/ a tarefa.

Durante a fase de compreensão do texto, os alunos devem buscar as palavras já conhecidas ou transparentes e buscar construir um sentido a partir delas. Retomando a biografia de Immanuel Kant, mencionada no item anterior, observamos que os alunos, sabendo o que poderia estar naquele texto, buscaram palavras conhecidas e semelhantes ao português (ou a outras línguas por eles conhecidas) para tentar entender os trechos.

Durante a fase de trabalho com a língua, pode-se trabalhar com as palavras conhecidas, desmembrando-as e buscando construir novas palavras a partir de radicais, prefixos e sufixos.

Como exemplo, mencionamos uma atividade apresentada por Angelika Gärtner em seu método "Lesekurs Deutsch: Curso de Alemão Instrumental", nas páginas 21 e 22, que aqui redigitamos. Ela retira palavras do texto apresentado e dá aos alunos outras palavras da mesma família, para que as classifiquem em termos de classes gramaticais:

Soziologie: sozialisieren, sozial, Sozialarbeiter, soziologisch

Adjektiv / adjetivo

Verb / verbo

Substantiv / substantivo

Soziologie

Adjektiv / adjetivo

Substantivkompositum/ substantivo composto

(Respostas: sozial - adjetivo, sozialisieren - verbo, soziologisch - adjetivo, Sozialarbeiter substantivo composto) 
Um quadro semelhante é proposto em seguida pela mesma autora para as palavras Menschenmasse, Menschen, menschlich e vermenschlichen (substantivo composto, substantivo, adjetivo e verbo, respectivamente).

A partir daí os alunos também podem chegar a regras de formação de palavras: quais sufixos formam adjetivos, como se montam substantivos compostos, etc.

Atenção seletiva / dirigida: atenção seletiva para aspectos específicos de uma tarefa, como buscar palavras-chave; scanning.

Essa estratégia se aplica mais à fase de compreensão do texto: estar consciente da tarefa proposta e dos meios para tentar executá-la deve ser o objetivo dos alunos. É importante lembrar que o gênero e o tipo de texto, e/ou os objetivos particulares, muitas vezes já determinam o tipo de compreensão, e o leitor deve voltar-se para alcançar essas metas, focando sua atenção para os aspectos que vão auxiliá-lo.

Em várias atividades e exercícios aqui propostos, como no caso da resenha do livro "Dialektik der Aufklärung", apresentada inicialmente no item perguntas sobre o conteúdo, os alunos devem estar cientes de que não precisam entender todas as palavras para cumprir os objetivos da tarefa proposta - que é a estratégia que utilizam até mesmo em língua materna, dependendo do que precisam ou querem fazer com um determinado texto. Além da prática em sala de aula, conversar a respeito com os alunos é uma forma de conscientizá-los disso.

Embora tenhamos dito que tal estratégia pareça se aplicar mais à fase de compreensão do texto, ela também pode ser utilizada durante a execução de um exercício lingüístico, já que os alunos também têm de se concentrar nos objetivos do exercício para completá-lo de forma adequada.

Skimming: correr os olhos pelo texto para captar a idéia global, ver do que se trata, se é um texto interessante para ler.

Essa estratégia pode ser combinada com a estratégia de utilização de conhecimento prévio e de contextualização para facilitar a leitura e deve ser, como toda estratégia, inicialmente guiada pelo professor, sendo, aos poucos, aplicada pelo aluno e incorporada à sua prática.

Ao se depararem com o índice de aulas na universidade retirado da Internet, por exemplo, os alunos podem correr os olhos pelo texto e dizer do que ele trata através da análise 
de elementos como a diagramação e por encontrarem algumas palavras conhecidas ou facilmente identificáveis. Podem, assim, escolher quais itens achariam mais interessantes para ler, ou seja, quais disciplinas parecem ser mais interessantes e nas quais "clicariam" para obter mais informações.

Contextualização: tentar compreender através da situação / de elementos nãolingüísticos.

Essa estratégia está sempre ligada às outras, em maior ou menor grau. Ativar os conhecimentos de mundo é necessário em vários momentos durante a leitura de um texto em um idioma que não se domina (e também em língua materna, obviamente). Isso tem que estar bastante claro para os alunos.

Se retomarmos as biografias aqui apresentadas, veremos que os alunos, apesar de não entenderem tudo, "se contextualizaram" para compreender os trechos: pensaram quais elementos estão geralmente presentes em uma biografia e procuraram indícios e caminhos no texto. Mais uma vez, praticar e conversar a respeito é uma forma de conscientizar os alunos dessa estratégia (assim como das outras) e de desenvolvê-la.

CICUREL (1991: 66-67) sugere, para o ensino do que ela chama de inferência e que aqui classificamos como estratégia de contextualização, colocar inicialmente perguntas a respeito do texto, em relação aos seguintes elementos (quando presentes e relevantes): lugar, agente, tempo, ação, instrumento, categoria, objeto, causa-efeito, problema-solução, sentimento-atitude. É importante ressaltar que esses mesmos elementos podem ser reformulados e utilizados como "perguntas abertas", das quais já tratamos, ou seja, também durante / após a leitura do texto.

\section{Dedução: partir da regra para entender usos e exemplos.}

Durante o trabalho com a língua podem ser destacadas orações que possuem estruturas já vistas para serem analisadas e reforçar / revisar o que veio anteriormente. A revisão é sempre importantíssima, e a recorrência de termos e estruturas certamente ajudará na fixação das regras e dos significados. Durante a leitura também pode ser feito esse trabalho de revisão / rememoração das regras para auxiliar na compreensão de determinados trechos, quando, por exemplo, surgem dificuldades. 
Diversas vezes, durante as leituras do nosso curso, os alunos tiveram problemas de compreensão, mas, ao ser lembrada a regra, o entendimento tornou-se mais fácil. Assim, acreditamos que é interessante utilizar esse recurso em alguns momentos em que a compreensão não se dá devido a problemas com a estrutura lingüística.

Análise: tentar compreender analisando a estrutura lingüística.

Durante a fase de compreensão, os alunos vão se valer do conhecimento lingüístico que possuem e das regras com as quais já trabalharam para entender trechos do texto, e até mesmo para chegar a novas regras. O professor pode estimular os alunos a fazer essa análise em momentos que julgar adequados. Também podem ser elaborados exercícios de análise durante a fase de trabalho com a língua.

Comparação: tentar compreender comparando com outras estruturas ou outros idiomas.

Essa estratégia se usa em conjunto com outras estratégias e é importante à medida que o conhecimento prévio, também lingüístico, ajuda a criar associações e a entender o novo. Pode ser feita em diversos momentos na aula, por conta própria, a pedido do professor ou com seu auxílio.

Utilização de conhecimento prévio: utilizar conhecimento prévio, como o conhecimento de mundo, para compreender.

Essa estratégia está presente em praticamente todas as outras e pode ser aplicada em diversos momentos, como na inferência de palavras desconhecidas (cujos sentidos podem ser revelados pelo contexto e pelo conhecimento do aluno de como funciona o mundo) e nas estratégias que envolvem mais a linguagem, como a tradução, a comparação e a análise (que só poderão ser feitas com base em conhecimentos lingüísticos prévios). Está intimamente ligada à estratégia de contextualização, de que já falamos.

Síntese: sintetizar ao longo da leitura, mentalmente ou por escrito, para compreender. 
Principalmente em passagens mais complicadas e que geram custos cognitivos grandes devido a dificuldades lingüísticas ou de conteúdo, o professor pode ir pedindo que os alunos vão sintetizando os trechos com orações simples ou palavras-chave, mentalmente ou por escrito, para que não percam a visão do todo. O próprio aluno pode se valer da síntese em diversos momentos da leitura para monitorar sua compreensão.

\section{Tradução: traduzir para compreender.}

A tradução é útil principalmente no início da aprendizagem da língua e também em trechos de textos que apresentam alguma dificuldade de compreensão. Como exercício lingüístico, pode ser bastante esclarecedora e ajudar a despertar a consciência lingüística do aluno no que diz respeito à estrutura da nova língua, a variações e nuanças de sentido, ambigüidade, diferentes formas de expressão, etc.

É importante ressaltar que a tradução pode ser tanto um exercício de compreensão quanto um exercício lingüístico. No caso da compreensão, basta uma tradução aproximada, que mostre que o aluno compreendeu um determinado trecho. Quando é um exercício lingüístico, há necessidade de uma maior exatidão. Devemos lembrar, entretanto, que ela não é o objetivo final de cursos para leitura, ou seja, os alunos não se tornam tradutores após tais cursos, embora saiam sabendo, em geral, traduzir pequenos trechos geralmente para fins particulares. Segundo BAZIJEV e TROJANSKAJA apud SCHRÖDER (1988: 138), a tradução pode ser tida como o objetivo da aula, como forma de controle e/ou como meio para a compreensão. Para esses autores, na fase inicial a tradução é apropriada, devendo ser escrita; na segunda fase é oral, e na terceira já nem precisa ocorrer. Aqui vemos a tradução como forma de controle e meio para a compreensão, principalmente durante o trabalho com iniciantes.

Voltando ao que diz respeito às estratégias em geral, fica claro que não se trabalha unicamente com uma estratégia, mas podemos pensar em termos de ênfase ou predominância e tentar desenvolvê-las em diversos momentos, tanto durante a fase de compreensão do texto quanto durante o trabalho com a língua.

Em relação às estratégias metacognitivas, o professor pode conversar com os alunos sobre como eles executam as tarefas, planejam seu estudo e avaliam a si mesmos, promovendo discussões e dando sugestões. As estratégias de memorização também devem ser apresentadas aos alunos e eles devem experimentá-las, conversando periodicamente na aula 
sobre aquelas com as quais trabalharam, quais lhes foram úteis e quais não. As estratégias sociais podem ser desenvolvidas durante trabalhos em grupo; o professor pode depois conversar individualmente com alunos que se apresentarem mais problemáticos, e o mesmo vale para as estratégias afetivas.

Voltando agora aos exercícios relacionados à questão lingüística, há um grande número de possibilidades, e aqui apresentamos mais algumas sugestões.

Para a conscientização em relação às combinações de letras do novo idioma, podem ser feitos exercícios de forca com palavras que estavam no texto, já vistas e/ou pertencentes ao vocabulário técnico (no caso dos cursos stricto-sensu). Para a conscientização quanto à organização dos elementos em uma oração, podem ser completadas orações em que falta o sujeito, o objeto do verbo, um conector, etc. Pensando também na questão textual, pode ser trabalhada a pontuação (colocar os sinais em um texto sem pontuação ou em orações); completar orações iniciadas por conectores; sublinhar conectores e dizer qual sua função; dizer a que elemento se refere um determinado pronome ou termo (anáfora / catáfora); procurar sinônimos, antônimos, hiperônimos e hipônimos no texto, entre outros. Também podem ser feitos exercícios de tradução (e versão) de orações ou pequenos trechos, de construção de palavras a partir de radicais, prefixos e sufixos, modificação/ transformação de orações, conjugação de verbos, tabelas de regras. Ou seja, os exercícios podem e devem envolver tanto o léxico quanto a gramática.

Outros exercícios interessantes que envolvem compreensão textual, estratégias e conhecimento lingüístico são: segmentar um texto sem divisões em parágrafos e justificar o porquê de tal divisão; e colocar em ordem trechos embaralhados de um texto. Também podemos pensar em dar títulos ou subtítulos a textos ou trechos, e no chamado "telegrama", que consiste em reescrever um texto com apenas algumas palavras, como se fosse um telegrama (ou seja, utilizando palavras-chave).

É importante ressaltar mais uma vez que exercícios de produção podem contribuir para a fixação / memorização de estruturas e de vocabulário, servindo apenas para a conscientização da língua, já que em cursos para leitura os alunos em geral não têm a produção como objetivo. Pensando nisso, deve-se também, ou principalmente, preparar exercícios que correspondam ao que os alunos têm que fazer com o texto na vida real. Desse modo, em todos eles, tanto nos de compreensão quanto nos lingüísticos, é interessante trabalhar bastante com exercícios que envolvam a estratégia de inferência, já que os alunos sempre se depararão com palavras desconhecidas e em diversos momentos poderão ter alguma dificuldade de compreensão. É importante que os alunos tentem descobrir palavras 
através do contexto, de elementos não-verbais e da forma (pelo fato de as palavras serem cognatas ou internacionalismos, através de regras de formação de palavras, ou pela combinação desses procedimentos). O co-texto também pode ser relevante: explicações, paráfrases, definições, descrições, generalizações, relações lógicas (como causa e consequiência). No plano do texto, isso pode se dar a partir da criação de uma expectativa de leitura, da análise de títulos e de subtítulos, bem como de elementos não-verbais e do contexto. $^{103}$

E para chegar às palavras-chave de um texto o aluno também tem um caminho a percorrer que deve ser praticado. Essas palavras só existem considerando-se sua relação com outras palavras no texto. Segundo CAVALCANTI (1989: 75):

“(...) são consideradas indicadores da busca de equilíbrio entre a comunicação e a criatividade (...) Servem como espinha dorsal para o estabelecimento de conteúdo proposicional e força ilocucionária, ativam as estruturas de conhecimento (esquemas) e os sistemas de valores do leitor; e subjazem à construção de pressupostos em relação ao todo ou parte do texto."

Para buscá-las, deve-se atentar ao plano principal do discurso, ou seja, o título, o início do texto, etc. Além disso, essas palavras costumam aparecer várias vezes, costumam ser tematizadas quando ocorrem pela primeira vez, são modificadas (através de adjetivações, por exemplo) e refere-se a elas com freqüência (através de repetições, pronomes, uso de sinônimos, hiperônimos, etc.). Isso também pode ser praticado com os alunos. Porém, para tanto é necessário que haja uma boa compreensão do texto, o que é geralmente difícil na fase inicial de cursos para leitura.

Quanto aos exercícios em geral, é sempre interessante que o professor tente resolvê-los por si só ou que peça a um colega para fazê-lo antes de aplicá-los. Isso ajuda a verificar se eles são adequados e se os enunciados estão claros. No caso da compreensão textual, é aconselhável tentar responder as perguntas antes da leitura do texto (no caso de perguntas relacionadas ao conteúdo, múltipla escolha, e verdadeiro ou falso, por exemplo), para ver se elas não são óbvias e se não podem ser respondidas independentemente da leitura.

No caso das estratégias, pode-se construir os exercícios levando-as em conta. Ou seja, pode-se incluir nos próprios exercícios questões como: que tipo de palavra é essa? Com que outras palavras ela pode aparecer combinada? Há uma relação entre ela e determinado trecho

\footnotetext{
103 Entretanto, essa técnica de "adivinhação" pode ser bastante limitada em alguns casos, sobre o que discorreremos mais tarde.
} 
do texto? Que idéias você tem e que associações faz ao pensar em tal palavra? ${ }^{104}$ Isso vale não só para perguntas que devem ser respondidas por extenso, mas também para questões de verdadeiro ou falso e de múltipla escolha, por exemplo.

Independentemente do foco (ou do principal foco) dos exercícios, é importante que eles sejam variados, para que haja um desenvolvimento mais amplo em diversos sentidos e para manter a motivação dos alunos. Além disso, o professor deve dar alguma liberdade para que os alunos trabalhem da maneira como acharem melhor em determinados momentos, e saber (re)adaptar seus objetivos, prioridades e exercícios de acordo com o feedback que recebe do grupo. Também vale relembrar que a revisão é sempre importantíssima, pois ela ajudará a fixar estruturas e vocabulário. Por isso é interessante que o professor retome constantemente estruturas e palavras já vistas, que procure textos em que elas reapareçam e que as inclua nos exercícios.

Para finalizar, também é importante relembrar que os exercícios devem corresponder ao que os alunos fazem ou têm que fazer na vida real, ou então servirem para desenvolver estratégias e ampliar conhecimentos lingüísticos. Segundo SCHRÖDER (1988: 123):

\begin{abstract}
“(...) auch für diese [Übungen zu Grammatik und Syntax] gilt, dass sie zur Entwicklung des verstehendes Lesens beitragen sollen und nicht zu reinen Strukturübungen werden dürfen; es müssen entsprechend funktionale Übungen sein, die am Inhalt orientiert sind und zur Entschlüsselung der Textinformation beitragen." 105
\end{abstract}

A gramática e o trabalho lingüístico têm, assim, a função de auxiliar no processo de compreensão. Quanto aos exercícios de controle, eles também devem ser elaborados de forma que o aluno mostre o que compreendeu, e que use a língua e as estratégias como um auxílio para essa compreensão. Lembramos que praticar é diferente de medir: podemos usar os mesmos exercícios ou exercícios semelhantes tanto durante a aula, para a prática de estratégias e aperfeiçoamento do conhecimento lingüístico, quanto para avaliar o aluno, mas é preciso saber adaptar os exercícios adequadamente para o momento da avaliação. E, por fim, devemos lembrar que o melhor exercício para desenvolver a habilidade de leitura é ler, e que isso deve ser feito com frequiência, em boa quantidade e da forma mais prazerosa possível.

\footnotetext{
${ }^{104}$ Baseando-nos em WESTHOFF (1997: 98).

105 “(...) também é válido para estes [exercícios de gramática e sintaxe] que devem contribuir para o desenvolvimento da compreensão leitora e não se tornar meros exercícios estruturais; de acordo com isso, devem ser exercícios funcionais, orientados para o conteúdo e que contribuam para a decifração da informação textual." (tradução minha).
} 
Segue uma tabela, não exaustiva, com alguns dos exercícios aqui propostos:

\begin{tabular}{|l|l|}
\hline Exercícios de compreensão & Exercícios lingüísticos / textuais \\
Perguntas ligadas ao conteúdo & Trabalhar com sinônimos / antônimos / \\
Perguntas abertas & hipônimos / hiperônimos \\
Verdadeiro ou falso & Compor / decompor palavras \\
Múltipla escolha & Analisar palavras \\
Cloze (cloze clássico, cloze múltipla & Formar sintagmas / unir palavras \\
escolha, cloze ao contrário) & (Re)estabelecer a pontuação \\
Correspondência & Fazer orações \\
Paráfrase & Modificar / transformar orações \\
Comentário & Analisar orações \\
Síntese & Completar orações \\
Tabela & Sublinhar elementos e identificar funções \\
Palavras-chave & Conjugar verbos \\
Diagrama & Encontrar a referência (anáforas, etc) \\
Lacunas & Segmentar texto em parágrafos \\
Tradução & Colocar trechos em ordem \\
& Cloze \\
& Telegrama \\
Forca \\
Dar títulos e subtítulos \\
Traduzir / verter \\
Formular tabela / esquema de regras \\
Agrupar palavras relacionadas entre si \\
\hline
\end{tabular}

No curso por nós ministrado, buscávamos, ao ser apresentado o texto, trabalhar com estratégias de contextualização e utilização de conhecimento prévio, com base nos aspectos extralingüísticos e elementos como títulos, subtítulos e autor. Após essa fase de pré-leitura, era feita, na fase de leitura, uma ou mais atividades de compreensão, de acordo com o gênero textual e o conhecimento prévio dos alunos (compreensão global, seletiva ou total), momento em que predominaram estratégias de esclarecimento / verificação, inferência, transferência, atenção seletiva / dirigida, tradução, contextualização, dedução, comparação e utilização de conhecimento prévio. Em seguida era destacado um aspecto gramatical para ser aprofundado 
e palavras importantes que os alunos deveriam memorizar para aumentar seu vocabulário. Nesse momento predominavam as estratégias de inferência, indução, tradução, análise e comparação. Em geral a fase de conscientização / fixação ocorria logo após a fase de leitura, e os alunos faziam exercícios para compreender melhor as estruturas que estavam aprendendo. $\mathrm{Na}$ fase pós-leitura, faziam comentários sobre o texto ou sobre outros aspectos relacionados ao assunto.

É importante lembrar que a língua de comunicação utilizada era sempre o português, já que o objetivo dos alunos não era a compreensão / produção oral.

Devido à baixa carga horária e para otimizar os objetivos - e também para aproximar as atividades e exercícios àquilo que os alunos realmente têm de fazer na vida real -, os exercícios mais utilizados foram, para a compreensão, perguntas abertas, perguntas ligadas ao conteúdo, síntese, comentário, correspondência, paráfrase, tabela, diagrama e tradução. Já em relação aos exercícios lingüísticos / textuais, os exercícios mais freqüentes foram os de analisar palavras e orações, fazer a correspondência, sublinhar elementos e identificar funções, e traduzir. Muitos deles eram feitos dentro do próprio texto, e não em separado. Exercícios de produção foram pouquíssimos, utilizados principalmente no início, para uma maior conscientização de alguns aspectos (como o genitivo, por exemplo).

Notou-se a necessidade muito grande da tradução, o que fez dela um dos exercícios mais utilizados ao longo de todo o curso. Essa necessidade se deu por várias razões: em primeiro lugar, o texto também era a base de aprendizagem de vocabulário, o que ocorria principalmente através de tradução e memorização; além disso, para muitos dos textos a compreensão global ou seletiva não bastava - e para entender de modo total era necessário que se conhecessem todas ou quase todas as palavras. Voltaremos mais tarde a esse aspecto quando tratarmos das dificuldades e especificidades do curso. Antes de prosseguirmos, porém, falaremos um pouco sobre a questão da avaliação, já mencionada brevemente. 


\subsection{Avaliações}

Como já dito, os exercícios de controle, ou avaliações, podem ser exercícios semelhantes aos utilizados em sala de aula, mas adaptados para a prova. O professor deve, para isso, fazer um levantamento do que é necessário que o aluno saiba até aquele momento e elaborar questões em que ele poderá demonstrar esses conhecimentos. Deve-se sempre tomar cuidado com o grau de dificuldade (ou facilidade) das questões, formular enunciados claros e ser coerente com o que foi dado em sala de aula.

No curso por nós ministrado foram dadas duas avaliações no primeiro módulo. Na primeira avaliação a professora optou por não deixar que os alunos utilizassem o dicionário ou qualquer material de consulta, para ver como se sairiam e se estavam estudando. Nessa avaliação houve perguntas de compreensão textual e voltadas à aplicação de diversas estratégias em textos com que se havia trabalhado em aula (lista de aulas da universidade, citações e biografias), além de questões lingüísticas (como separar compostos e dar infinitivo de verbos) e tradução de trechos. As traduções, assim como era feito em aula, não precisavam ser perfeitas, mas uma aproximação que mostrasse que o aluno tinha entendido a idéia e a estrutura lingüística, bem como que conhecia o vocabulário. Todos os alunos tiraram notas acima da média (que era 7,0) nessa prova, sendo que a nota mais alta foi 9,75 e a mais baixa foi 7,15. Na última avaliação, em que foi permitido consultar todo o material e também o dicionário, os alunos leram descrições de livros e definições, procurando entender o tema geral (compreensão global) ou algumas informações (compreensão seletiva), e traduzindo / explicando alguns trechos (compreensão total). A nota mais alta foi 9,9 e a nota mais baixa foi 6,5, mas todos foram aprovados. Uma breve análise indicou que a maior fonte de erros não foram questões relacionadas à leitura, pois os alunos em geral foram bem nas questões de compreensão seletiva ou global, mas sim questões lingüísticas (falsa interpretação de palavras ou entendimento errôneo de estruturas). No segundo módulo demos uma prova mais longa, que foi feita em casa, e uma avaliação final presencial. Alguns poucos alunos desistiram no meio do curso, principalmente por falta de tempo, e outros foram reprovados por falta, mas o restante foi aprovado.

Além da avaliação convencional, para que o aluno tenha uma "nota" (exigida também por razões institucionais), é importante que o professor tente acompanhar o desempenho de cada um, ou seja, fazer o que poderia ser considerada uma avaliação processual. À medida que percebe que os alunos estão tendo dificuldades, o professor pode tentar detectar o 
problema e dar sugestões de estudo; já no caso de alunos bons, pode conversar com eles para buscar atender necessidades particulares, por exemplo.

Um outro tipo de avaliação é a avaliação do curso, que pode ser passada para os alunos, e em que eles devem dar sua opinião em relação aos aspectos que o professor julgar relevantes, como andamento da aula, professor, material, carga horária e freqüência, número de alunos, sala de aula, "matéria" em si, pontos positivos e negativos em geral. 


\section{Especificidades e dificuldades de cursos para leitura}

$\mathrm{Na}$ avaliação do curso por nós ministrado, passada para os alunos no final do primeiro semestre, perguntamos quais haviam sido os pontos positivos e negativos do curso, se ele havia atendido as expectativas e quais as sugestões para o semestre seguinte. A partir das respostas do grupo vamos tentar analisar e avaliar as dificuldades e especificidades do nosso curso, que podem ser válidas, em muitos casos, para outros cursos do mesmo gênero.

Em relação aos pontos positivos, os alunos comentaram que as aulas foram boas e bem elaboradas, e diversos alunos ressaltaram a dedicação da professora. Muitos comentaram que gostaram dos resumos de aula e do apoio que receberam através dos e-mails. O blog não foi tão mencionado quanto o e-mail, e infelizmente não teve o caráter idealizado inicialmente pela professora: a intenção era que nele houvesse troca entre os alunos e que ele pudesse ser um espaço de comunicação e interação, o que não ocorreu. Essa foi uma das dificuldades: como estimular os alunos a usar o blog? Como eles poderiam efetivamente utilizá-lo? Além disso, entrava a questão de que nem todos os alunos tinham acesso fácil à Internet e que não estavam acostumados em geral a um curso com esses elementos.

Em relação aos exercícios, embora alguém tenha dito que houve excesso de tarefas, a maioria afirmou o contrário: pediram mais tarefas de casa e mais trabalho individual. Essa foi mais uma questão problemática: a produção de material. Havia pouco tempo e também surgiu a dificuldade de elaborar exercícios específicos para um curso para leitura, que são diferentes de exercícios utilizados em cursos comunicativos. A falta de modelos e de idéias dificultou o trabalho. Mas em relação ao pedido dos alunos, no segundo módulo, o trabalho individual foi proposto como tarefa de casa, devido ao pouco tempo de aula.

Algumas pessoas também sugeriram a utilização de uma apostila, o que não era possível no momento porque o curso ainda estava sendo elaborado. Embora acreditemos que, pelo menos para o primeiro semestre de um curso como o nosso, seja possível elaborar um material mais genérico que serviria para qualquer grupo que quisesse ler textos de Filosofia e Ciências Sociais em alemão, por outro lado a escolha das citações e das biografias (gêneros textuais trabalhados então), por exemplo, foi feita de acordo com o interesse dos alunos, manifestado nos questionários. Ou seja, a questão do material é um problema intrínseco ao caráter dos cursos para leitura, que são elaborados de acordo com as especificidades de cada grupo, mesmo que a partir de uma base já pré-estabelecida. Uma possibilidade é justamente 
utilizar um material pré-elaborado, que poderia valer para qualquer grupo, e que fosse sendo "enxertado" com materiais mais específicos de acordo com os interesses de cada classe. Ao falar do currículo comunicativo, SÁNCHEZ (1993: 147) diz que ele deveria ser parcialmente aberto, e acreditamos que, no caso de cursos para leitura, isso seria o ideal.

Em relação às estratégias, em uma das avaliações houve um comentário relevante a esse respeito. A aluna em questão disse que algumas estratégias eram interessantes (estava se referindo a algumas estratégias utilizadas nos momentos de compreensão global e seletiva), mas que não eram suficientes para os tipos de textos que queriam ler. E aqui entra a questão de que cursos para leitura costumam ser ministrados para públicos mais abrangentes, e devido a essa heterogeneidade são utilizados textos mais gerais, como artigos de jornais e revistas, para os quais a compreensão global ou de determinadas informações é suficiente. Os textos utilizados por nós no primeiro semestre também eram textos que permitiam, principalmente no início, uma compreensão global ou seletiva, diferentemente dos textos que vieram depois e que eram o principal objetivo dos alunos. Como trabalhar com a compreensão total se não há um domínio da língua? É claro que a velocidade da leitura fica comprometida, e que o próprio caráter dos textos das áreas do nosso curso exija uma leitura mais lenta, mesmo em língua materna: não é apenas a "informação transmitida" que importa, mas também a análise das palavras escolhidas, de como se compõe o texto e quais as nuanças e possibilidades de interpretação. A própria língua se torna objeto de reflexão.

Assim, embora todas as estratégias e os exercícios de compreensão global e seletiva sejam úteis e auxiliem, eles parecem não bastar. CARRELL (1990), por exemplo, diz que resultados de estudos levam à conclusão de que conhecimentos gerais relativos ao tema de um texto antes de sua leitura facilitam a compreensão, assim como o treinamento / ensino explícito da estrutura formal do texto. Acreditamos que esses conhecimentos facilitam, sim, mas não bastam, já que a compreensão por completo se dá semântica e sintaticamente. LÖSCHMANN e PETZCHLER apud SCHRÖDER (1988: 81) ressaltam o papel da semântica:

"Die Informationen werden den Zeichen entnommen, ohne dass sich der Leser bewusst Rechenschaft über ihre syntaktische Verknüpfung gibt. Der Verstehensprozess wird dabei in erster Linie semantisch gesteuert."106

Alguns autores, ao contrário, relevam o papel da sintaxe, pois sem ela orações ficam assemânticas; ou seja, mesmo sendo conhecidos os sentidos das palavras, a estrutura lógica e

\footnotetext{
106 "As informações são retiradas dos signos sem que o leitor se dê conta conscientemente de sua conexão
} sintática. O processo de compreensão é assim conduzido em primeira linha semanticamente.” (tradução minha). 
a relação entre os termos seriam dados pela sintaxe, podendo-se inclusive, em alguns casos, adivinhar o léxico a partir de outros elementos e das relações entre eles numa mesma oração. Outros estudiosos ainda defendem a importância do conhecimento da estrutura do texto, o que leva também à necessidade de ter tido muito contato com outros textos semelhantes. ${ }^{107}$

Uma posição intermediária, também defendida por nós, é que o que está no plano lingüístico e da forma não pode ser separado do plano do conteúdo. Nesse sentido, tanto a semântica quanto a sintaxe seriam relevantes, bem como a estrutura do texto, e só a partir de uma interpretação semântica com base na sintaxe poder-se-ia seguir rumo a uma interpretação pragmática (do sentido do todo). Ou seja, o leitor se defronta simultaneamente com o plano da língua, com o plano da forma (textual) e com o plano do conteúdo, mas, se há problemas na interpretação semântica, dificilmente se chega ao entendimento do todo: palavras desconhecidas são um obstáculo, pois nem todas podem ser inferidas pelo contexto ou analisadas em suas partes. Muitos erros não decorrem da inabilidade de leitura, já que, no caso do nosso curso especificamente, acreditamos que os alunos em questão são leitores fluentes em língua materna, pois estão envolvidos com áreas do saber em que a habilidade de leitura tem um peso importantíssimo. É, assim, o desconhecimento das palavras e a interpretação errônea de estruturas que os impedem de chegar ao sentido do todo (ou a um sentido qualquer). Segundo DABENE e QUET (1999: 117), os psicolingüistas distinguem várias habilidades de leitura, como a decodificação, a compreensão literal (tratamento lexical e sintático) e a inferencial (integração, que ligaria os enunciados; extração, que é a retirada de idéias principais e pressupõe uma seleção rápida das informações dadas pelo texto; e a elaboração, que liga o texto aos saberes e experiências de cada leitor). Isso acontece em etapas quando se trata da leitura de um texto em língua estrangeira, principalmente com alunos iniciantes: primeiro a decodificação e a compreensão literal, a partir da qual se dá a inferencial. No leitor proficiente elas podem acontecer (quase que) simultaneamente, mas, se não há as primeiras, não se pode chegar à última. GAONAC'H (1990: 44) diz que vários trabalhos mostram que o papel dos índices de alto nível (utilização do contexto, referência a uma estrutura textual típica) parece ser menos importante em língua estrangeira do que em língua materna. O mesmo autor (1990: 44) diz que "tout se passe comme si les insuffisances linguistiques avaient pour effet de 'court-circuiter' la mise en oeuvre des processus de haut niveau." 108

\footnotetext{
${ }^{107}$ Para essa discussão, ver SCHRÖDER (1988: 86).

108 “(...) tudo acontece como se as insuficiências lingüísticas tivessem como efeito 'curto-circuitar' a utilização de processos de alto nível.” (tradução minha)
} 
Para MEURER (1988: 265-266), três causas da falta de compreensão seriam a falta de esquemas relativos ao conteúdo; a posse de tais esquemas, mas a incapacidade de ativá-los por algum motivo; e/ou a formação de uma representação mental diferente da pretendida pelo autor / pelo texto. Acreditamos que tais fatores também possam causar problemas durante a leitura, mas somente após a primeira etapa de decodificação e compreensão literal, ou durante essa fase. É nela que nossos alunos parecem encontrar mais dificuldades, pois em geral são hábeis em ativar esquemas pertinentes. GAONAC'H (1990: 48) diz que o baixo nível de automatização de um certo número de processos em língua estrangeira leva o indivíduo a dar mais atenção a eles do que em língua materna; trata-se, em geral, de processos de baixo nível, e essa situação gera um custo cognitivo maior. Na mesma página, esse autor diz que "pour un apprenant, toute activité langagière en LE constitue de fait un exercice, même si son but premier n'est pas celui-là."109

Assim, parece ter sido a falta de vocabulário o fator mais importante para a falta de compreensão, bem como a insuficiência de conhecimento das estruturas lingüísticas ou a análise equivocada dessas estruturas. Embora toda aula a professora selecionasse palavras para os alunos irem memorizando, isso nem sempre acontecia, e algumas pessoas tinham uma grande dificuldade de memorização ou não se esforçavam para isso. Essa é uma questão também bastante difícil: como memorizar as palavras? É possível elaborar exercícios que auxiliem nesse sentido? É necessário que o aluno reconheça o significado das palavras para que construa sentidos. Seria interessante trabalhar com textos em que as palavras se repetissem, mas isso se mostrou difícil, principalmente quando os textos são selecionados de acordo com os interesses dos alunos. Com textos fabricados ou previamente selecionados segundo critérios de ensino (gramaticais ou de vocabulário), talvez isso fosse mais fácil.

Ainda de acordo com as avaliações respondidas pelos alunos, alguns deles acharam, em relação à fase pós-leitura, que os comentários eram desnecessários ou vagos, ou que levavam a discussões irrelevantes para os objetivos da aula - o que, na verdade, surpreendeu a professora, que inicialmente tinha uma expectativa maior em relação aos comentários dos alunos e julgava que discussões seriam freqüentes, o que não se mostrou verdadeiro. Acreditamos que isso se deva ao fato de muitos alunos não serem realmente especialistas nas áreas e também de os textos do primeiro módulo serem mais genéricos, assim como os conhecimentos lingüísticos serem poucos para levar a discussões também nesse âmbito.

\footnotetext{
109 “(...) para um aprendiz, toda atividade linguageira em língua estrangeira constitui de fato um exercício, mesmo que não seja esse seu objetivo inicial.” (tradução minha)
} 
Outro fator problemático, apontado como negativo por vários alunos, foi a curta duração do curso. ${ }^{110}$ Realmente a carga de informações gramaticais e também de palavras novas foi muito grande, o que fez com que o curso tivesse um caráter de introdução à língua alemã e também de introdução à leitura de textos das áreas em questão nesse idioma. Aos alunos foi recomendado um estudo fora da sala de aula para aqueles que realmente quisessem se aprofundar, também pelo fato de em aula só serem trabalhados trechos de textos. Tentando suprir essa necessidade, e tendo como objetivo a autonomia do aluno para continuar aprendendo a língua e para ler textos de seu interesse fora da aula (também após o término do curso), trabalhamos, a partir do final do primeiro semestre, com a comparação dos originais com traduções. Trataremos a seguir dessa questão da tradução, bem como da aprendizagem de vocabulário.

\footnotetext{
${ }^{110}$ VAN PASSEL (1983: 35) diz, ao tratar de um curso de língua estrangeira envolvendo as quatro habilidades, que um aluno médio precisaria de mais ou menos 200 horas para ter um conhecimento elementar da língua estrangeira. Em se tratando de uma única habilidade, poderíamos nos basear no seu cálculo para tentar estipular um mínimo de horas e colocar isso à prova. Acreditamos, porém, que tudo dependa muito de diversos fatores, principalmente do público-alvo, da frequiência das aulas e da língua ensinada/aprendida.
} 


\subsection{A questão da tradução e do vocabulário}

Desde o início, a tradução foi um dos elementos mais freqüentes nas aulas do curso para leitura. Como o texto era o único contato do aluno com a língua, não havia outra maneira de aprender palavras novas senão através do próprio texto; e para aumentar o conhecimento da língua, justamente para poder ler outros textos, foi necessário desde o início que se pensasse na ampliação de vocabulário. E isso se deu principalmente através da tradução e da análise, quando possível, dos vocábulos. Essas palavras novas deveriam ser memorizadas pelos alunos, o que nem sempre era feito - ou então as palavras que haviam sido memorizadas em algum momento eram esquecidas. Disso surgiram várias questões, como: qual o papel da língua materna na aprendizagem de uma língua estrangeira, e, mais especificamente, no caso de cursos para leitura? Como memorizar palavras novas e como trabalhar com a tradução?

O papel da língua materna é claro em um curso para leitura, como aqui já tratamos. Ela é a língua utilizada pelo professor e pelos alunos para se comunicarem, já que estes não têm a produção lingüística como objetivo. Além disso, segundo L. DABÈNE (1994: 8), a língua materna, para o professor de língua estrangeira, é:

“(...) 'le substrat langagier' de l'élève, la première occupante du terrain, celle dont on ne peut faire abstraction même si on décide pour des raisons méthodologiques de la tenir à l'écart (...)."111

E, como lembra JOVANOVIC (1992: 177), a língua materna "sempre acabou sendo uma espécie de baliza, de ponto de referência - positiva ou negativa - para as diversas abordagens". SLAMA-CAZACU (1979: 86), por sua vez, afirma que "o estudo das línguas estrangeiras se faz sobre o fundo de um código anteriormente assimilado e que funciona já há algum tempo, pelo menos." A mesma autora (1979: 101) lembra que, durante o estudo de uma outra língua, não se formam apenas hábitos lingüísticos, mas também há "modificações da estrutura mental, adaptações à maneira de pensar, de 'recortar' a realidade (...)”. Ela ainda se pergunta se hábitos lingüísticos estabelecidos na primeira língua podem ser anulados "a tal ponto que a verbalização seja inibida e o indivíduo não recorra à sua língua materna", e se é possível anular o pensar na língua materna. Ora, acreditamos que a "adaptação" aos novos hábitos lingüísticos só ocorra justamente porque há uma base inicial a ser considerada e que

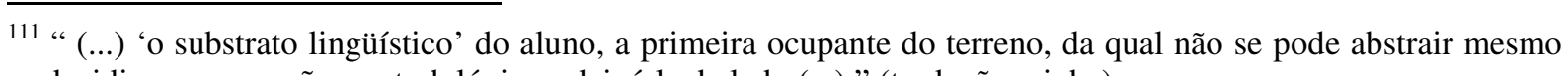
se decidimos, por razões metodológicas, deixá-la de lado (...).” (tradução minha) 
não pode ser simplesmente apagada; resta saber, porém, se sobre essa base pode ser construída uma outra que, embora inicialmente fixada na língua materna, acaba tendo uma certa independência em alguns aspectos, mas que o indivíduo pode acabar "atravessando" para chegar à inicial em diversos momentos, conscientemente ou não. A nosso ver, parece ser isso o que acontece, embora nos baseemos aqui apenas em intuições e reflexões a respeito, e sejam necessárias pesquisas para que se chegue a resultados e conclusões confiáveis.

No caso de um curso para leitura, o texto, como já dissemos, é o único contato dos alunos com a nova língua, e dele são retiradas palavras para serem aprendidas e que, para tanto, acabam sendo naturalmente traduzidas. Durante a fase de compreensão, porém, ao serem encontradas palavras desconhecidas (que mais tarde serão ou não aprendidas), um caminho muito utilizado - e encontrado na literatura a respeito - é a "adivinhação" de palavras pelo contexto. RUBIN (1981) apud DICKINSON (1987) diz que bons aprendizes de línguas, para tentarem chegar ao significado de um trecho, usam pistas como a ordem dos itens na oração, a estrutura sintática, o contexto e o tópico do discurso, e qualquer outro indício visual. Baseando-nos nisso e em WESTHOFF (1997: 98), já aqui mencionado, podemos pensar em algumas perguntas para a utilização dessa estratégia de inferência ${ }^{112}$ : que classe de palavra é? Ela se parece com palavras que você já conhece? Pode ser dividida em partes? Qual sua relação com as palavras vizinhas? Que significado(s) faria(m) sentido nessa oração e de acordo com o que veio antes e o que vem depois no texto?

Embora seja um item recorrente em guias para trabalhos com textos em sala de aula, a "descoberta" de palavras pelo contexto ou co-texto, porém, só se dá quando são poucas as palavras desconhecidas. Essa inferência se mostrou, no nosso caso, útil em poucos momentos, quando o contexto já era conhecido (como ao lermos biografias e algumas definições), e muitas vezes ainda com o apoio morfológico, ou seja, com a análise da palavra em suas partes.

Além disso, essa adivinhação não parece ajudar na memorização dos vocábulos. Ao tratar de estratégias de leitura, muitas vezes consideradas como de aprendizado, ARNAUD e SAVIGNON (1997: 159) dizem que:

“(...) guessing in context (...) is, strictly speaking, a reading strategy, not primarly a vocabulary acquisition strategy; although its use involves semantic treatment of the input and therefore may facilitate incidental learning (Hulstijn, 1992). Experimental results, however, do not

\footnotetext{
112 Já mencionadas no item 3.6.
} 
unanimously show such an effect of guessing on vocabulary retention (Mondria \& Wit-de Boer, 1991)." 113

E a leitura se prova realmente impossível sem o conhecimento das palavras. LAUFER (1997: 20) afirma que:

\begin{abstract}
"No text comprehension is possible, either in one's native language or in a foreign language, without understanding the text's vocabulary. This is not to say that reading comprehension and vocabulary comprehension are the same, or that reading quality is determined by vocabulary alone (...)." 114
\end{abstract}

Completando a afirmação acima, isso quer dizer, porém, que, apesar de serem vários os fatores que influenciam na leitura, o vocabulário é certamente fundamental. SMITH (1989: 81) afirma que é da informação visual que os leitores devem extrair sentido, embora a leitura seja muito mais do que a mera identificação dessa informação; de qualquer forma, ler é o que se faz com essa informação, ou seja, é ela o ponto de partida da leitura. BUGGENHAGEN (1968), na sexta página de seu prefácio, também já diz que "sem um perfeito conhecimento do vocabulário morfológico, não há possibilidade de desenvolver-se lingüisticamente nem mesmo a compreensão passiva do idioma estrangeiro" (grifos meus). Embora discordemos de que esse conhecimento deva ser perfeito - e que isso seja impossível, mesmo para um falante nativo - e acreditemos que "nem mesmo a compreensão passiva" dê a idéia de que é a leitura é uma habilidade simples, talvez "menor" do que as outras (sem entrar, ainda, no mérito da questão "ativo" versus "passivo"), vemos que esse aspecto já era tido como importante em uma época anterior ao "furor comunicativo". CHAGAS (1979: 253), por sua vez, afirma que os progressos dos estudantes de línguas estrangeiras, no que diz respeito à leitura, "estão na dependência direta do vocabulário antes assimilado e do seu próprio grau de integração no espírito do idioma." E CALAQUE (1995) ainda ressalta a importância da atitude de receptividade, de boa memória e de atenção / concentração do leitor. Essa receptividade e atenção / concentração deveriam estar presentes não só durante a leitura, mas também no momento de memorização de vocabulário, que deveria existir.

\footnotetext{
113 “(...) adivinhar no contexto (...) é, falando de modo estrito, uma estratégia de leitura, não primeiramente uma estratégia de aquisição de vocabulário; embora seu uso envolva tratamento semântico do input e, portanto, possa facilitar o aprendizado acidental (Hulstijn, 1992). Resultados experimentais, entretanto, não mostram unanimemente tal efeito da adivinhação na retenção do vocabulário." (tradução minha)

114 "Nenhuma compreensão textual é possível, seja em língua materna, seja em língua estrangeira, sem o entendimento do vocabulário do texto. Isso não quer dizer que compreensão leitora e compreensão do vocabulário sejam a mesma coisa, ou que a qualidade de leitura é determinada apenas pelo vocabulário (...)" (tradução minha)
} 
COIRIER et al. (1996: 213) dizem que a insuficiência de vocabulário parece provocar um "curto-circuito" na utilização de processos de alto nível; além disso, afirmam (1996: 185) que os elementos lexicais são as principais marcas que, em um texto, ativam representações ligadas aos conteúdos abordados pelo texto. LAUFER (1997: 21), por sua vez, afirma que: “(...) even if a reader has good metacognitive strategies, which he or she uses in L1, these will not be of much help in L2 before a solid language base has been reached."115 Ela cita várias pesquisas que chegaram à conclusão de que o maior problema dos leitores em L2 não são as estratégias, mas a falta de vocabulário. Para decidir qual é a idéia principal, por exemplo, o que parece ser relativamente simples, precisamos entender bem o texto para podermos selecionar, criar, construir uma idéia. Segundo LEFFA (1999):

"Mesmo as abordagens interativas, que consideram tanto os aspectos
ascendentes, com base no texto, como os aspectos descendentes, com base
no leitor, privilegiam a orientação ascendente com ênfase em habilidades de
reconhecimento de palavras (Grabe, 1991). Mas são os estudos sobre o
movimento dos olhos na leitura, conforme levantamento feito por Chun \&
Plass (1997), que parecem oferecer o suporte maior, mostrando dois
aspectos interessantes. Primeiro, tanto os leitores principiantes como os
leitores mais proficientes processam praticamente todas as palavras do
texto, de modo menos ou mais automático, dependendo justamente do grau
de proficiência. Segundo, contrariando o mecanismo de previsão -
proposto por Smith (1994), Goodman (94) e outros - a grande maioria das
palavras são reconhecidas antes que as informações contextuais possam
influenciar o acesso lexical.".

O mesmo autor (1999) ainda diz que a competência lexical parece ser o fator crítico da compreensão, sendo suplantado por outros elementos, como conhecimento do tema e da estrutura discursiva. Ou seja, a compreensão realmente está fortemente ligada ao conhecimento do vocabulário, talvez mais do que a outros aspectos, e a deficiência nesse sentido pode ser a principal causa da falta de compreensão.

Dentre os problemas citados por LAUFER (1990) em relação à não-compreensão, além da falta de vocabulário, estão palavras aparentemente conhecidas, mas que enganam por diversos motivos: por terem transparência enganosa ou estrutura morfológica enganosa, por serem falsos cognatos ou expressões idiomáticas, por terem vários significados ou por serem "synforms", que são pares ou grupos de palavras semelhantes na forma. Outros problemas estão ligados às palavras que não podem ser inferidas durante a leitura de um texto pelas seguintes razões: falta de pistas, falta de familiaridade com as palavras que contêm as pistas,

115 “(...) mesmo que um leitor tenha boas estratégias metacognitivas que ele ou ela usa em L1, elas não serão de muita ajuda em L2 antes que uma base lingüística sólida tenha sido alcançada." (tradução minha) 
pistas parciais ou que levam a caminhos errados, e incompatibilidade entre os esquemas do leitor e o conteúdo do texto. A mesma autora acredita que o fator principal para uma boa leitura é o número de palavras no léxico do aluno, que para o inglês seriam 3000 famílias ou 5000 itens lexicais. Isso cobriria $90-95 \%$ de qualquer texto, e as outras palavras poderiam ser inferidas através de estratégias. Abaixo desse número de palavras, as estratégias seriam ineficazes. VAN PASSEL (1983: 47), por sua vez, fala de cerca de 1000 palavras para o que chama de conhecimento elementar, em se tratando de qualquer idioma, e 2000 palavras para o que chama de conhecimento básico. O mesmo autor (1983: 28) ainda menciona orações-tipos, estruturas utilizadas em vários contextos, e elementos-ferramentas (palavras gramaticais), que comporiam um conjunto de 250 a 300 termos que "é preciso assimilar a qualquer custo" (e, segundo ele, para essa assimilação seriam necessárias cerca de 100 horas de aprendizagem). Infelizmente desconhecemos estudos específicos para o alemão, mas poderíamos inicialmente nos basear em uma aproximação de acordo com esse levantamento para a elaboração de materiais ou para pesquisas na área.

É claro que a estrutura sintática e a gramática não podem ser deixadas de lado, mas, segundo WIDDOWSON apud ZIMMERMANN (1997: 13), falantes nativos conseguem entender melhor afirmações agramaticais com vocabulário adequado do que orações com gramática precisa e vocabulário inadequado. Talvez isso se dê também com leitores estrangeiros. O'MALLEY e CHAMOT (1990: 64) dizem que "even after years of exposure to a second language, the processing speed of individuals fails to match the processing speed achieved in their native language." 116 Segundo os mesmos autores (1990: 65), estudos revelaram que falantes nativos mostram maior reconhecimento de mudanças semânticas do que sintáticas da leitura de um trecho, enquanto os não-nativos se concentram mais na forma. Isso sugere que os nativos se prendem ao significado e processam os aspectos estruturais automaticamente, enquanto os não-nativos têm que prestar atenção tanto ao significado quanto à estrutura e às palavras.

Assim, acreditamos que seja importante saber palavras e, para tanto, é necessário que se saiba memorizá-las e analisá-las. Uma vantagem que os adultos têm, segundo SCLIARCABRAL (1988: 47), é que a "aquisição do léxico (...) pode ser facilitada com a maturidade, através de estratégias metalingüísticas conscientes (...)”. Cremos, assim, ser necessário que haja estratégias de vários tipos para a retenção das palavras. Mas como fazê-lo? Parece haver dois caminhos básicos: através de associações e de repetição (que pode ocorrer, por exemplo,

\footnotetext{
116 “(...) mesmo após anos de exposição a uma segunda língua, a velocidade de processamento dos indivíduos
} não consegue ser equivalente à velocidade de processamento alcançada na língua materna." (tradução minha) 
quando há uma freqüência alta de leitura). Parece haver um certo impedimento da memorização no começo do aprendizado devido ao estranhamento com os padrões silábicos do novo idioma, mas aos poucos as associações começam a ser feitas até mesmo intralingüisticamente, ou seja, com palavras da própria língua estrangeira. No caso de cursos para leitura, embora o objetivo não seja a produção ou a compreensão oral, é interessante que as habilidades orais sejam minimamente desenvolvidas, porque tanto a forma gráfica quanto a fonológica permitem o estabelecimento de associações e também podem ser um fator auxiliar na fluência de leitura, embora faltem estudos a respeito e haja controvérsias nesse sentido. De qualquer forma, concordamos com PIETRARÓIA (2001: 125) quando ela fala da “focalização sobre a forma (sonora e gráfica) no início da aprendizagem lexical, constituindo não um comportamento errôneo, mas um passo fundamental na estruturação do léxico mental, assegurando nele um 'lugar', uma primeira entrada, para a palavra estrangeira."

SLAMA-CAZACU (1979: 102-103) diz que várias experiências têm enfatizado o papel da "familiaridade" com as palavras, tanto para sua percepção quanto para sua memorização. Segundo a autora, é provável que palavras mais familiares, que estejam mais disponíveis na língua materna, sejam aprendidas mais rapidamente na língua estrangeira. Por outro lado, a autora também afirma, baseando-se em BOUSFIELD (1953), que os sujeitos tendem a agrupar palavras apresentadas em ordem aleatória em "famílias", e não de acordo com a ordem apresentada. Acreditamos que isso talvez mostre uma "tendência natural" para a associação, uma tentativa de buscar sentido onde não há, de buscar regras dentro do caos, que é próprio do ser humano.

CHAGAS (1979: 228-250), por sua vez, distingue, entre os processos para o ensino/ aprendizagem de vocabulário, o contexto, a observação, a associação, a analogia (morfológica, etimológica e semântica), o contraste e a repetição. Entretanto, uma mesma palavra pode ter vários significados, que se modificam de acordo com a situação. GIASSON (1990: 203) nos lembra que é difícil encontrar um contexto que dê informações completas sobre uma palavra nova. É necessário que se encontre essa palavra mais de uma vez, e para isso seria necessária uma grande quantidade de leitura.

ESKEY e GRABBE apud FERREIRA (1998: 51) acreditam justamente "mais na quantidade de leitura feita do que na quantidade dos exercícios propostos", o que parece ser a opinião de vários estudiosos. RIVERS (1975: 225), embora dentro de um outro contexto e com o olhar e as bases de uma outra época, já dizia que: 
“(...) a leitura abundante é fator fundamental para o desenvolvimento da fluência nessa atividade e o aluno deverá ser encorajado a ler muito. Isto somente será possível se o assunto despertar nele interesse genuíno e for condizente com sua faixa etária; deverá aproximar-se, tanto quanto possível, do tipo de material que desejaria ler em língua materna."

No que diz respeito ao léxico, PARIBAKHT e WESCHE (1997), por sua vez, afirmam que a retenção é maior se após a leitura é feito um trabalho com exercícios relacionados ao vocabulário. Mas como fazer que haja uma maior repetição para ajudar os alunos a fixar uma palavra e também a vê-la em outros contextos? Para que o aluno leia, é preciso que entenda, e para entender é preciso que leia. Como quebrar esse ciclo? Como sair das fases iniciais? Parece ser necessário que o material seja cuidadosamente elaborado, de modo que as palavras realmente se repitam, recorrendo talvez também a textos adaptados ou fabricados. A vantagem de um material previamente elaborado é de ser talvez mais adequado didaticamente. Materiais prontos podem dar segurança ao professor, pois, conforme nos lembra BOHN (1988b), eles são em geral escritos "por pessoas altamente qualificadas, são testados e apresentados em condições gráficas que normalmente só as grandes editoras podem oferecer”, sendo, a nosso ver, mais atraentes por isso. Entretanto, pode-se ter uma importante desvantagem, apontada por PRETTO apud CARDOSO-SILVA (2006: 14) em relação ao papel dos livros didáticos em escolas:

“(...) o professor exerce sempre um papel secundário em que não lhe cabe decidir nada, pois o livro não só determina tudo que deve ocorrer na sala de aula como também despreza completamente o nível de conhecimento dos professores e as necessidades e expectativas dos alunos".

Assim, para haver essa repetição, seria necessário selecionar cuidadosamente textos, ou mesmo fabricar e adaptar alguns, e elaborar exercícios em que palavras que devem ser memorizadas reapareçam. Ou, como já propusemos, é possível elaborar um material que serviria como a base das aulas, ao qual poderiam ser acrescentados textos de acordo com cada grupo. Para a memorização parece ser também interessante que se façam analogias e associações (e que o professor dê vários exemplos), também com base morfológica. Em uma das avaliações sobre o curso que ministramos, um aluno chegou a sugerir que a professora fornecesse ao final de cada aula "uma lista de 5 a 10 palavras para memorização como tarefa de casa. Memorizando tais palavras, o aluno poderá, no início da próxima aula, traduzir um texto sem consulta ao dicionário e compreendê-lo em seu significado (...)”. A sugestão é boa, mas em parte já estava sendo realizada: as palavras novas que apareciam na aula deveriam ser 
memorizadas, embora nem todos fizessem esse trabalho de memorização. Já a questão de iniciar a aula seguinte com textos com tais palavras é bem mais complicada, devido à dificuldade de encontrar materiais. Seria necessário fabricar ou adaptar textos.

E o uso do dicionário? Em um curso para leitura ele é extremamente utilizado e pode ser muito útil, assim como outras obras de referência. Em um estudo de caso que fez consigo mesmo para aprender a ler textos em português, William Grabe chegou à conclusão de que um dicionário bilíngüe é um importante recurso, se utilizado corretamente. GRABE e STOLLER (1997: 114), ao analisarem esse caso, dizem que o sujeito analisado "appreciated the support he gained from using the dictionary. Frequently, he felt that too much guessing led to great frustration."117 Mas, segundo alguns estudos, seu uso não parece auxiliar muito na memorização. É necessário que haja algo a mais para que seja feita uma associação, com conseqüente memorização, que pode ser, a nosso ver, um trabalho morfológico.

Esse trabalho morfológico, que foi feito na maioria das vezes de maneira espontânea durante nosso curso, sem muitos exercícios de apoio, auxiliou não só no descobrimento de palavras desconhecidas; em casos em que não se pôde "adivinhar" a palavra, seu desdobramento em partes, após a revelação do significado pelo dicionário ou pelo professor e o estabelecimento de uma associação, também auxiliou na memorização. Para exemplificar, temos inicialmente o caso da palavra "ausstellen", que tem como um de seus significados “expor”. Os alunos não conseguiram descobrir do que se tratava só pelo contexto; após terem buscado o significado no dicionário, o professor mostrou-lhes que tal vocábulo era composto do prefixo "aus-" (que vem da preposição "aus", que significa "fora de", sendo que o prefixo "aus-" pode ter o sentido de "para fora") e do verbo "stellen", que significa "colocar", "pôr". O professor então mostrou que a palavra "ausstellen" era exatamente igual à palavra portuguesa "expor" (ex + pôr) detalhe ao qual os alunos não haviam atentado até então. Fazer essa associação permitiu que essa palavra fosse lembrada mais adiante. O mesmo ocorreu com a palavra "mitmachen", que significa "participar", "acompanhar". Desmembrando-a, os alunos chegaram ao verbo "machen" (fazer) e à preposição / ao prefixo "mit" (com). Após terem consultado o dicionário e encontrado aqueles significados, fez sentido para eles que "fazer com, fazer junto" significasse "acompanhar", "participar", o que auxiliou na memorização.

Como vemos nos exemplos acima, no caso da língua alemã, em que a transparência em relação ao português é mínima, uma forma fundamental para inferir e para memorizar

117 “(...) gostou do apoio que recebeu através do uso do dicionário. Ele freqüentemente sentia que muita adivinhação levava a uma grande frustração.” (tradução minha) 
palavras é a análise morfológica, e acreditamos que é um ponto fundamental para qualquer tipo de curso de alemão (e até mesmo de outras línguas), não só em se tratando de cursos para leitura. LUNEAU (1978: 4-5) fala sobre um trabalho semasiológico, que seria do significante para o significado (que é o que normalmente se faz) e de um trabalho onomasiológico (do significado para significante), que é o que fizemos nos dois exemplos acima, com os verbos "ausstellen" e "mitmachen".

HULSTIJN (1997: 203-224) também fala do "key word method" ("método da palavrachave"), que consistiria em associações com uma palavra-chave para a retenção de uma palavra na língua estrangeira. Essa palavra-chave pode ser encontrada por semelhança fonética ou de conteúdo, ou simplesmente ajudar a formar uma imagem mental. Para facilitar a retenção, é necessário que haja um trabalho em relação à forma e ao significado da palavra. Segundo seus estudos, parece que esse método não ajuda tanto na produção quanto na recepção; poderia ser útil, assim, em cursos para leitura.

Como exemplo, podemos pensar na associação feita por diversos alunos da palavra "Hals", que significa "pescoço", "garganta", com a famosa bala "Hall's", que refresca a garganta; ou, ainda, na associação feita por uma aluna da palavra "Spiegel” (espelho) com a palavra portuguesa "espiga", e a imagem de uma espiga de milho refletida em um espelho. Nesses casos, as palavras-chave seriam "Hall's" e "espiga", que nada têm a ver com os significados das palavras "Hals" e "Spiegel”, mas que formam uma "ponte" até eles.

Essas seriam formas de memorização eficazes e que parecem funcionar bastante, pelo que pudemos observar no curso de nossa experiência em sala de aula, principalmente se as associações têm um toque humorístico. É importante, em qualquer tipo de curso, que os alunos tenham consciência de que é necessário aprender palavras novas, tanto para compreender (principalmente no caso de línguas bastante diferentes da língua materna) quanto para produzir, e que aprender uma língua é um eterno aprender palavras novas.

OXFORD e SCARCELLA apud COADY (1997: 278) dizem que o professor deve ensinar os aprendizes a como continuar aprimorando o vocabulário por conta própria através da apresentação e prática de estratégias de aprendizagem de vocabulário adequadas, e não simplesmente deixar que os alunos aprendam palavras novas da maneira que acharem melhor. Embora discordemos um pouco dessa afirmação - pois acreditamos que os alunos devem escolher o jeito que lhes parece mais produtivo não só para memorizar palavras, mas para aprender qualquer coisa -, acreditamos também que o professor deve expor diversas estratégias para que os alunos tenham diante de si uma gama maior de possibilidades, que poderão experimentar para poder escolher a que lhes parecer mais útil. 
Dentre as diversas estratégias de memorização já apresentadas por nós em uma tabela no item 3.6., há a repetição / revisão de palavras e trechos, que pode ser feita através da anotação de palavras, da elaboração de listas, da audição de uma gravação com as palavras (que pode ser feita pelo próprio aluno), da releitura de trechos e ao fazer exercícios (inclusive ao refazê-los), e também através da simples repetição em voz alta ou por escrito. Orações, estruturas e trechos também podem ser memorizados por repetição, o que pode ser feito, por exemplo, através do emprego de música, que parece ser uma forte aliada na memorização. Em geral, as pessoas têm bastante dificuldade em memorizar um poema, mas se lembram facilmente de letras de músicas enormes, que nada mais seriam do que poemas musicados.

Além disso, temos a aplicação de imagens, sons e cores. Para isso pode-se desenhar ou imaginar figuras, fazer um mapa semântico ou associar palavras semelhantes entre si foneticamente. Como exemplo, para se memorizar o gênero de uma palavra ${ }^{118}$, pode-se associar a nova palavra com cores (azul para o masculino e rosa para o feminino, por exemplo) ou imaginá-la com uma palavra que tenha o mesmo gênero e que já seja conhecida do aluno. Como exemplo, podemos citar o caso da aluna que dizia "colocar" as palavras masculinas em um "armário" (Schrank, palavra masculina em alemão, que ela já conhecia) para se lembrar de que eram desse gênero, enquanto as palavras femininas ela colocava na "cômoda" (Kommode, palavra feminina em alemão), sendo que as neutras ficavam dentro do "carro" (Auto, palavra neutra). Em relação aos sons, alguns exemplos: os alunos memorizaram facilmente a palavra "Eis" por saberem inglês e conhecerem a palavra "ice" (gelo), que é pronunciada exatamente como "Eis", embora seja grafada diferentemente. E por terem feito essa associação, facilmente se lembravam de que "Eis" em alemão também quer dizer "sorvete" (já que ambas as coisas são geladas). E a palavra "Berg" foi então memorizada como "montanha" devido à palavra "iceberg" (montanha de gelo), que os alunos já conheciam do próprio português. Ou seja, aí vemos diversos tipos de associações, feitas através de sons e também de critérios escolhidos pelos alunos. Esse também é um exemplo de criação de associações mentais, que pode ser feita segundo qualquer critério.

O mapa semântico, por sua vez, pode ser elaborado com uma palavra e outras derivadas dela. Pensemos, por exemplo, na palavra Arbeit (trabalho). Ela poderia ficar no centro de uma folha ou em um canto, e a seu lado poderiam ser agrupadas outras palavras relacionadas, como no exemplo abaixo, com ou sem tradução:

\footnotetext{
${ }^{118}$ No caso do alemão, se a palavra é masculina, feminina ou neutra, distinção importante principalmente para a produção do aluno, mas que também pode ser crucial em trechos de leitura para a idenficação da função dos elementos da oração, quando estão declinados.
} 


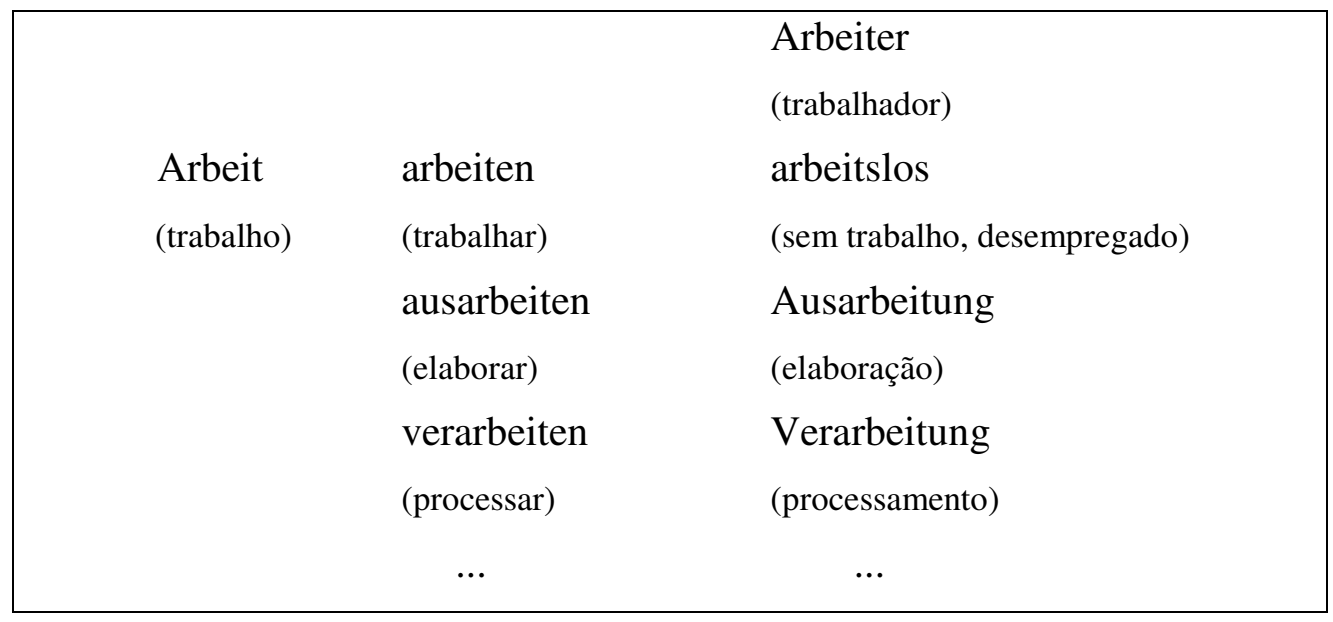

Nesse caso, poderíamos colocar em cores diferentes os substantivos, os adjetivos e os verbos, ou seja, separar as palavras por classes gramaticais, mas o aluno pode fazer do jeito que achar melhor.

Além disso, pode ser elaborado um tipo de "mapa" que batizei como "roteiro de aula": o aluno começa escrevendo a primeira palavra nova que apareceu na aula e, a partir dela, vai se lembrando do que aconteceu na seqüência, das palavras que vieram em seguida, por que uma coisa levou à outra, etc. É como se montasse a "história" da aula com palavras-chave. É uma boa forma de revisão que parece estimular a memória e também divertir. Se pensarmos que essa revisão funciona como uma história, acreditamos que estaremos ajudando na memorização e seguindo talvez tendências naturais do funcionamento do cérebro, pois, segundo ROSEN (1986) e outros autores apud SMITH (1989: 214): ${ }^{119}$

“(...) o cérebro humano é, essencialmente, um dispositivo de narrativa. Funciona à base de histórias. O conhecimento que armazenamos no cérebro, em nossa 'teoria do mundo', está amplamente na forma de histórias. Estas são muito mais facilmente recordadas e lembradas do que seqüências de fatos não relacionados uns aos outros."

ANDERSON (1985) apud O’MALLEY e CHAMOT (1990: 49) também fala do "method of loci", um dispositivo mnemônico usado para relembrar uma seqüência ordenada de itens. Por exemplo, imagina-se um determinado caminho em um lugar familiar (por exemplo, de casa para a escola) e visualiza-se que os itens a serem memorizados (por exemplo, palavras) estão interagindo com objetos conhecidos ao longo do caminho.

\footnotetext{
${ }^{119}$ SMITH (1989: 61) ainda lembra que as pessoas tendem a recontar uma história lida com a mesma forma estrutural.
} 
Por fim, há ainda o emprego de ação, que consiste no uso de gestos para se lembrar de uma seqüência ou uma oração, por exemplo. $\mathrm{O}$ aluno memoriza os gestos como se fossem "passos de dança" para lembrar a frase. Mencionamos aqui essa estratégia, mas concordamos em parte com SLAMA-CAZACU (1979: 115), ao falar do método de "resposta física total", que um procedimento como esse "coloca o adulto em situações ridículas, mas não tem, no fundo, outro resultado senão a aprendizagem de verbos como 'saltar', etc." Embora essa não pareça ser a única aplicação dessa técnica (orações podem ser memorizadas com gestos sem que incluam necessariamente verbos de movimento, por exemplo), ainda assim concordamos que não parece ser sempre adequado para os adultos e que pode causar situações constrangedoras.

COHEN e APHEK (1981) apud DICKINSON (1987: 130) enumeram algumas das técnicas (que aqui chamamos de estratégias e atividades) utilizadas por aprendizes bemsucedidos: associar a estrutura, parte ou toda a palavra com uma palavra na língua-alvo; associar o som de uma nova palavra com o som de uma palavra na língua materna, na línguaalvo ou em uma outra; construir a imagem mental de uma palavra; lembrar-se da situação em que a palavra ocorria; lembrar-se da sensação física associada à palavra; visualizar a palavra; associar palavras com terminações semelhantes. Os mesmos autores apud O'MALLEY e CHAMOT (1990: 107) concluíram, após pesquisas, que alunos que tinham feito associações pareciam reter as palavras memorizadas com mais freqüência do que os que não as haviam feito, e que o sucesso em sua aprendizagem parecia independente da freqüência com a qual os alunos (re)encontraram as palavras fora da aula.

ELLIS e SINCLAIR (1990: 173-174) sugerem, para a prática de estratégias de memorização, que o professor dê uma lista de palavras para os alunos na aula, que eles terão de memorizar em um determinado tempo, e que depois discuta com eles a respeito, apontando-lhes novos caminhos. SOULE-SUSBIELLES (1990: 178-179), por sua vez, sugere algumas questões que acreditamos que podem ser feitas aos alunos para despertar sua consciência em relação ao modo como agem: como você aprende uma palavra nova? Como você memoriza um palavra nova? Como você aprende uma estrutura nova? Como você memoriza uma estrutura nova? Essa autora também conclui que pode ser que alguns alunos se valham de determinadas estratégias por serem as únicas que conhecem, e que o problema seria uma incompetência tática (que poderíamos chamar de estratégica), e não necessariamente (apenas) dificuldades com a língua.

É interessante mencionar o que NAIMAN et al. apud O’MALLEY e CHAMOT (1990: 7) dizem a respeito das estratégias relacionadas à aprendizagem de vocabulário: elas 
são as mais freqüentemente usadas, e isso pode se dar porque os alunos têm dificuldades para identificar quais técnicas (que aqui chamamos de atividades, e incluiríamos também as estratégias) eles utilizam em outras tarefas, ou não sabem como fazê-lo; ou seja, não sabem usar estratégias pra outras coisas.

Em suma, essas são algumas das estratégias e atividades para o aprendizado de palavras novas, e acreditamos que as estratégias auxiliam por serem significativas, relevantes e por trazerem envolvimento pessoal, fatores apontados por SMITH (1989: 123), ao tratar da questão da leitura, como essenciais para a rememoração fluente - e que devem poder ser aplicados a qualquer tipo de rememoração, como a aprendizagem de palavras novas. Aprender novos vocábulos é um dos elementos presentes no estudo de qualquer idioma, embora aprender uma língua não se resuma a isso. É importante, porém, ter um mínimo de vocabulário para o que quer que se queira fazer com o novo idioma, seja ler, escrever, falar ou entender algo que se ouve. NATION apud COADY (1997: 280) diz que as 2000 palavras mais freqüentes deveriam ser aprendidas o mais rápido possível através de quaisquer meios, incluindo materiais para leitores iniciantes e ensino direto, enquanto alunos que querem ler textos acadêmicos devem se concentrar no que ele chama de "vocabulário acadêmico ou subtécnico". Segundo ele, para esses alunos o ideal é uma combinação de leitura e de instrução de vocabulário.

De qualquer forma, parece ser mais fácil reconhecer palavras do que ter de reproduzilas: é a diferença entre memória de reconhecimento e de reprodução. Segundo SMITH (1989: 306), reconhecer algo é mais simples do que imaginar ou reconstituir porque precisamos produzir menos detalhes - que já estão lá - para identificar do que para reproduzir. Às vezes é necessário ver só parte de uma imagem ou de uma palavra para saber do que se trata, enquanto reproduzir significa refazer todos os detalhes, sem omitir ou errar. Nesse sentido poderíamos dizer que os alunos de cursos para leitura têm uma certa vantagem, já que não precisam usar palavras produtivamente; têm de "apenas" reconhecê-las.

Em qualquer caso, ao aprender palavras novas é comum, principalmente no início, que se traduza. Em um curso para leitura a tradução sempre acaba acontecendo, quer o professor queira, quer não. Como o texto é o único contato do aluno com a língua, inicialmente é normal que haja esse procedimento. Aos poucos, com a ampliação de vocabulário, a compreensão de estruturas e a prática, o aprendiz deverá poder ler diretamente, sem o intermédio da tradução. O trabalho a que nos referimos de comparação da tradução com o texto original - que COSTA (1988: 289) chamou de "exame de traduções" e classificou como "particularmente interessante do ponto de visto lingüístico como cultural" - mostrou-se muito 
útil, no curso por nós ministrado, para ampliar a consciência lingüística do aluno. Isso se deu porque as traduções costumam ser bastante diferentes do original, no sentido de que nelas aparecem sinônimos e paráfrases que soam de modo mais natural na língua de chegada (no caso, o português), embora na língua de partida (o alemão) sejam usados outros vocábulos ou construções. Além disso, essa comparação parece ter auxiliado na compreensão das estruturas da língua alemã, que são bem diferentes das da língua portuguesa, bem como na aprendizagem de vocábulos, de expressões e de algumas construções específicas, não literais em relação ao português. COSTA (1988: 283) diz inclusive que:

"Uma concepção mais ampla, mais cultural e crítica pode colocar a tradução como um dos meios mais eficientes de se estar permanentemente atento às diferenças em relação à língua (e à cultura) estrangeira. Contrariamente ao que se supõe, este procedimento pode ser muito mais eficaz porque revela, de maneira mais clara, as dificuldades e pode facilitar a sua superação."

WIDDOWSON (1979: 61) apud COSTA (1988: 285) corrobora essa afirmação, dizendo que a tradução "pode ser um procedimento pedagógico muito útil e, em certas circunstâncias, especialmente quando uma língua estrangeira é aprendida para "fins específicos', a tradução de certo tipo pode fornecer o meio mais eficiente de aprendizagem." É importante lembrar que a questão da tradução que é discutida aqui - e no ensino/aprendizagem de línguas em geral - é a chamada tradução interlingual (diferenciada em relação à tradução intralingual, ou reformulação, e a tradução inter-semiótica, ou transmutação). COSTA (1988: 288) ainda lembra que "quanto mais distante estiver a língua estrangeira da língua materna maior necessidade haverá de um uso sistemático da tradução nas fases iniciais". E mesmo no caso de línguas mais próximas, segundo esse autor, a chamada tradução de esclarecimento deve ser usada para evitar mal-entendidos.

Voltando ao curso por nós ministrado, os alunos, ao terem de traduzir trechos que mais tarde comparavam com o original, ainda puderam praticar a consulta a obras de referência, como dicionários e gramáticas. No caso dos estudantes em questão, que muitas vezes precisam entender com precisão do que trata uma determinada passagem ou capítulo, esse trabalho de tradução de pequenos trechos é bastante importante. Como exemplo, citamos uma aluna que nos contou, informalmente, que havia lido duas traduções do mesmo texto alemão, uma para o espanhol e outra para o francês, e que as traduções divergiam entre si. Como era um ponto importante para sua pesquisa, ela buscou o trecho original em alemão e o traduziu para tentar entender melhor e ver qual das traduções que ela havia lido era a mais adequada. 
Em suma, é importante que seja feito um trabalho com vocabulário e que se saiba usar a tradução de forma adequada, pois ela pode ser muito útil, e acaba sendo inevitável em cursos para leitura (e em outros também). COSTA (1988: 289) a chama inclusive de "quinta habilidade”. Embora os alunos de um curso para leitura não saiam tradutores, eles deverão saber como traduzir pequenos trechos para ajudar na compreensão, quando necessário, ou mesmo para fins acadêmicos ou particulares. Devido aos métodos comunicativos existentes, entretanto, a tradução é vista em geral de forma bastante negativa, mas pode ter um lugar muito importante em sala de aula, se usada apropriadamente.

Assim, todos esses trabalhos com o vocabulário e com a tradução podem ser feitos e contribuir para a aprendizagem de palavras novas e para a compreensão do novo idioma, pois só sabendo muitos vocábulos e conhecendo as estruturas é que os alunos poderão inferir algumas das poucas palavras desconhecidas que aparecerem no texto e adquirirão, através de prática, pelo menos uma certa fluência em leitura. Voltaremos a tratar um pouco mais dessa questão da leitura no próximo item. 


\title{
5.2. A questão da leitura
}

\author{
Segundo CARDOSO-SILVA (2006: 18):
}

\begin{abstract}
“(...) a leitura é um fenômeno cuja definição torna-se difícil na medida em que, envolvendo um leitor e um texto, abrange uma multiplicidade de processos cognitivos básicos como percepção, memória, associação verbal e afetividade. Para Ross (1979, p.5), uma definição de leitura precisaria incluir tanto a decifração de símbolos escritos como a identificação do significado desses caracteres, isto é, tanto aspectos perceptivos como cognitivos e afetivos do comportamento."
\end{abstract}

VIGNER (1979: 29-30), por sua vez, fala em três momentos iniciais de leitura: a detenção do signo (perceber que ele existe), a identificação (conseguir opô-lo a outro signo) e a interpretação (dar-lhe significado). ${ }^{120}$ Em qualquer idioma, dependendo de vários aspectos que envolvem também a consciência lingüística e metalingüística do aluno e a proximidade do idioma estudado com sua língua materna ou com línguas conhecidas por ele -, há uma detenção nesses processos cognitivos básicos num momento inicial, e também em momentos em que há dificuldade de leitura, mesmo quando ela já é fluente. ${ }^{121}$ No caso específico do alemão, acreditamos que isso acontece mais e por mais tempo do que em se tratando de línguas mais próximas ao português e por isso mais transparentes. No nosso caso, etapas aplicáveis a outros idiomas, principalmente ao francês, sobre o qual existem muitos estudos, parecem não ser exeqüíveis, pelo menos não no mesmo espaço de tempo, devido à falta de transparência das palavras e à diferença de estruturas. Ou seja, é necessário que a leitura vá sendo praticada aos poucos, à medida que se vai ganhando vocabulário e "incorporando" estruturas novas, para que se chegue a um grau mínimo de fluência, o que pode levar tempo, dependendo do caso.

Já no que diz respeito à atividade de leitura em si e aos seus objetivos, CAVALCANTI (1989: 30-33) propõe, baseando-se em TANNEN \& WALLET, o uso do termo condicionantes externos, que aqui entendemos, de acordo com a autora, como as variáveis impostas no momento da leitura. ${ }^{122}$ Para nós, elas incluem também a situação de leitura, ou

\footnotetext{
${ }^{120}$ No original: détection du signal, identification, interprétation.

${ }^{121}$ RIVERS (1975: 211-212) fala dos significados lexical, estrutural (gramatical) e sociocultural que devem ser "extraídos", sendo que os primeiros seriam justamente os lexicais e estruturais, embora no leitor fluente tudo aconteça simultaneamente.

122 TANNEN e WALLAT, segundo a autora, propõem o termo "esquemas" para estruturas de conhecimento e "moldura" (que ela chama de condicionantes externos) para estruturas superordenadas impostas sobre eventos. (1989: 30)
} 
seja, quem, quando, onde, como, por que e o quê. No nosso caso, tentamos aproximar a leitura em sala de aula o máximo possível da leitura em "ambiente natural". Apesar de a aula ser vista como um espaço artificial, concordamos com M. DABENE (1994: 9) quando ele diz que:

"on peut lire à l'école pour remplir toutes les fonctions de la lecture: lire pour apprendre mais aussi lire pour faire, lire pour dire, lire pour trouver une réponse, lire pour imaginer, lire pour apprécier, etc. Il est donc important, d'un point de vue didactique, que l'évaluation du savoir-lire s'insère dans un réseau diversifié de projets e de tâches de lecture integré aux activités scolaires, dans une perspective de régulation des apprentissages". ${ }^{123}$

LITTLEWOOD (1981: 44) afirma que a sala de aula também é um contexto real, onde os alunos e o professor estabelecem entre si relações sociais reais. GIASSON apud TURCOTTE (1994: 18) diz, por sua vez, que a leitura tem um caráter holístico e precisa de vários processos mentais que acontecem simultaneamente: atividade perceptiva, recurso ao léxico, construção do sentido das orações, elaboração de inferências, estruturação e avaliação das informações. Geralmente são processos não isolados, que acontecem de forma automática, a não ser que seja encontrada uma dificuldade. No caso do aprendiz de língua estrangeira, as dificuldades são várias, principalmente no começo, e o recurso ao léxico é limitado. CICUREL (1991: 11) aponta inicialmente três tipos de obstáculos encontrados pelo leitor que lê um texto em língua estrangeira: obstáculos lexicais (palavras desconhecidas), obstáculos ligados à organização textual (devido ao desconhecimento da sintaxe e até mesmo de tipos ou gêneros textuais) e obstáculos ligados ao domínio referencial (conteúdo, temas abordados, alusões, etc.). No nosso caso, tudo isso fica bastante claro: os textos escolhidos por nós, indicados muitas vezes pelos próprios alunos, propiciaram o tipo de leitura que os alunos teriam de fazer fora da sala de aula em geral, "desartificializando" um pouco o ambiente de sala de aula. Mesmo com esse aspecto envolvido e com uma motivação em geral alta, as dificuldades causadas por alguns dos processos cognitivos básicos, impedidos de atuar devido ao desconhecimento de vocabulário e estruturas, aumentaram o esforço cognitivo dos alunos e tornaram o trabalho às vezes bastante difícil. Não podemos nem mesmo saber se haveria problemas de interpretação pelo fato de não termos conseguido sair dos processos básicos.

\footnotetext{
123“"Pode-se ler na escola para cumprir todas as funções da leitura: ler para aprender, mas também ler para fazer, ler para dizer, ler para encontrar uma resposta, ler para imaginar, ler para avaliar, etc. Assim, é importante, de um ponto de vista didático, que a avaliação do saber-ler se insira em uma rede diversificada de projetos e de tarefas de leitura integrada às atividades escolares, em uma perspectiva de regulação das aprendizagens." (tradução minha)
} 
Acreditamos que obstáculos ligados à organização textual e ao domínio referencial podem acabar surgindo, mas quando não há problemas com o léxico e as estruturas. Essa primeira etapa, não se dando de maneira satisfatória, impede que se chegue às outras.

Mas como ajudar o aluno a ler, quando não são tantos os problemas com o vocabulário e as estruturas? GIASSON (1990) propõe, para o que ela chama de microprocessos, trabalhar com o reconhecimento de palavras (dar uma resposta instantânea a uma palavra que já foi identificada em outros momentos) e leitura por grupos de palavras (o que pode ser feito através da segmentação do texto em unidades utilizando critérios sintáticos, pausas ou sintagmas). Já no que diz respeito ao que ela denomina processos de integração, GIASSON (1990) lembra, de acordo com CUNNINGHAM, que há inferências fundamentadas sobre o texto e outras sobre os conhecimentos do leitor. ${ }^{124}$ Acreditamos que elas se mesclem em vários momentos. Em uma passagem complicada, por exemplo:

- se os alunos não entendem o significado de um conector, o professor pode auxiliá-los a ler o trecho seguinte para tentar estabelecer uma relação lógica e inferir o significado daquele conector;

- se os alunos não entendem um trecho iniciado por um conector, o professor pode pedir que completem o sentido da oração inicial + conector pensando no que aquele conector quer dizer e dentro da lógica / sequiência do texto.

Segue um exemplo simples, que daremos em português. Na seqüência: "Maria não foi à escola xxxx estava doente", os alunos não entendem o significado de "xxxx" e podem inferir, pela lógica, que seja "porque". A mesma oração poderia ser "Maria não foi à escola porque xxx yyy zzz." Os alunos poderiam inferir o motivo de Maria não ter ido à escola se valendo do "porque" no início da oração e de seu conhecimento de mundo, além do resto do texto (o que veio antes e o que virá depois).

Em se tratando do que GIASSON (1990) chama de macroprocessos, o aluno deve retirar a idéia principal do texto e saber resumi-lo, utilizando também sua estrutura. A idéia principal seria, grosso modo, a informação mais importante - mas ela é importante porque o autor a apresenta assim, ou seja, o aluno deve tomar cuidado para não retirar informações importantes para si e dá-las como informações importantes do texto. Além disso, acreditamos

\footnotetext{
${ }^{124}$ Esse mesmo autor diferencia a compreensão literal da inferencial, inferências lógicas e pragmáticas.
} 
que é necessário estabelecer uma diferença para o aluno entre "tema" (do que o texto trata) e "idéia principal" (o que o texto fala em linhas gerais).

Já o resumo, segundo LAURENT (1985) apud GIASSON (1990: 81-82) é:

"la réécriture d'un texte antérieur selon une triple visée: le maintien de l'équivalence informative, la realisation d'une économie de moyens signifiants et l'adaptation à une situation nouvelle de communication." ${ }^{25}$

Dependendo do tipo de texto e do gênero, o trabalho pode ser feito de diversas maneiras, mas é importante que o professor mostre quais passos os alunos devem seguir, exemplificando quando possível. Podemos pensar, ainda com base em GIASSON (1990), nas seguintes regras que um resumo deve seguir: eliminação (eliminar a informação secundária e a redundante); substituição (substituir uma lista de elementos por um termo englobante, por exemplo), macrosseleção e invenção (escolher o trecho que traz a idéia principal ou inventar um que a contenha). Para chegar a isso, o aluno deve já ter uma boa compreensão lexical e sintática da língua. É importante que compreenda bem antes de resumir, e técnicas como sublinhar trechos ou fazer anotações podem ser muito eficazes.

Em relação aos resumos, façamos uma breve exposição. VAN DIJK (1980; 2000) chama de estrutura de superfície o conjunto de microproposições (presentes na estrutura textual ou inferidas com base no conhecimento prévio), enquanto o sentido global do discurso é representado por macroestruturas semânticas. Ou seja, a estrutura de significado global de um texto é representada abstratamente na macroestrutura, que é uma reconstrução teórica de noções intuitivas como tópico ou tema de um discurso e é expressa, grosso modo, pelo resumo de um discurso. A macroestrutura explica, assim, o que é mais relevante na informação semântica de um discurso e fornece uma unidade global. Não é, porém, a soma das conexões de coerência entre as sentenças; resulta de uma transformação semântica e explica a coerência em geral, incluindo casos de coerência sem coesão. Essa transformação semântica se dá através de princípios ou regras denominados macrorregras. Macrorregras são, desse modo, regras de interpretação semântica que permitem uma (re)interpretação das sentenças como proposições globais ${ }^{126}$ e só operam com base no conhecimento de mundo.

\footnotetext{
125 “(...) a reescrita de um texto anterior segundo uma visão tripla: a manutenção da equivalência informativa, a realização de uma economia de meios significantes e a adaptação a uma nova situação de comunicação". (tradução minha)

${ }^{126}$ Simplificadamente, proposições seriam unidades de significado atribuídas às sentenças, derivadas das macrorregras, construídas com base no significado da palavra e na estrutura sintática. São compostas por um predicado e um certo número de argumentos. Seriam, a nosso ver, um "resumo" ou um "resumo esquemático" das orações.
} 
Elas apagam, generalizam ou constroem informação local, reduzindo a estrutura de sentido complexa, detalhada de um texto, a um sentido mais simples, mais geral e abstrato. As macrorregras são: (1) deleção (retiram-se proposições que não são macrorrelevantes); (2) generalização (tira-se de várias proposições o que elas têm em comum, ou seja, substitui-se uma seqüência de eventos específicos por um evento geral); (3) construção ("unem-se" as proposições que fazem parte de uma seqüência normal de fatos e podem ser substituídas por uma proposição final, que é construída com base no conhecimento prévio); e (4) seleção (escolhe-se a proposição mais macrorrelevante). Nas macrorregras 1 e 2 a informação está perdida; na 3 ela é parcialmente recuperável com base no conhecimento de mundo; na 4 ela é, em geral, totalmente recuperável.

Como exemplos, temos:

\section{$\underline{\text { Regra 1: Deleção }}$}

Passou uma menina. Ela estava usando um vestido amarelo.

Resultado: Passou uma menina.

("Ela estava usando um vestido amarelo" só não poderia ser apagado se esse fato tivesse consequiências mais tarde. Se for apenas uma descrição, pode ser deletado).

\section{Regra 2: Generalização}

Pedrinho estava jogando bola. Aninha estava penteando sua boneca e Paulinho estava montando um quebra-cabeça.

Resultado: As crianças estavam brincando.

\section{Regra 3: Construção}

Carlos correu, mas chegou tarde demais ao ponto de ônibus.

Resultado: Carlos perdeu o ônibus.

\section{Regra 4: Seleção}

Antônio foi até seu carro, entrou e dirigiu até a escola.

Resultado: Antônio dirigiu até a escola.

Para diferentes tipos de textos, as macrorregras podem ser utilizadas de maneiras diferentes. Além disso, elas são recursivas: podem ser aplicadas várias vezes num mesmo texto / trecho. Produzem-se, assim, "resumos" cada vez mais abstratos. 
Não nos aprofundando mais nessa questão, achamos importante ressaltar que as macroestruturas lidam com o conteúdo, enquanto as superestruturas, de que já falamos, estão ligadas à forma do texto. A idéia da macroestrutura é, assim, que o texto não tem apenas relações locais ou microestruturais entre orações subseqüentes, mas que tem também estruturas gerais que definem sua coerência global e sua organização.

Com alunos mais avançados, é interessante trabalhar com essas regras para a elaboração de resumos. NUNES (2004), ao tratar de cursos de inglês instrumental, vê a necessidade de ajudar os alunos "em suas habilidades de elaborar notas, fichamentos, resumos críticos, selecionar informações, enfim, aprimorar suas estratégias de estudos a partir de textos acadêmicos redigidos em inglês". Segundo essa autora, que se baseia em diversos autores, a tarefa de resumir é bastante complexa, sabe-se pouco a respeito, a capacidade do aluno de fazê-lo é superestimada e os processos envolvidos são ignorados. Praticar isso em sala de aula poderia ajudar, à medida que o professor mostra ao aluno como poderia proceder, para que, aos poucos, ele possa caminhar sozinho.

Voltando à divisão estabelecida por GIASSON (1990), no que diz respeito aos processos de elaboração a autora integra predições, imaginário mental, resposta afetiva, relação com conhecimentos e raciocínio. Nessa fase acreditamos que o trabalho possa ser feito em diversos momentos e com o auxílio das várias estratégias já aqui mencionadas, dependendo dos objetivos e das dificuldades que surgem. O mesmo ocorre para o que GIASSON (1990) chama de processos metacognitivos e que acreditamos que podem ser trabalhados durante a leitura com o auxílio das estratégias metacognitivas anteriormente apresentadas.

Resta uma questão: no caso dos alunos que se valem muito da tradução - e esse acaba sendo um procedimento muito adotado em cursos para leitura, como já falamos - ou mesmo em momentos de comparação do texto original com a tradução, será que podemos dizer que a leitura se dá, já que construção do sentido que fica é aquela que foi intermediada pela tradução? Acreditamos que sim. VIGNER (1979: 68) diz que:

"s'il est admis que le lecteur a compris le texte, ce n'est pas certainement parce qu'il a pu en retenir tous les mots. Il faut donc distinguer l'appréhension du sens, de la perception verbale, et postuler qu'il existe, dans le texte, une série de dispositifs dont la fonction est de favoriser le travail d'appréhension du sens, et d'alleger l'effort de perception verbale, 
permettre: 'de retenir partiellement les mots et intégralement le sens' (Séleskovitch, 1975)". ${ }^{127}$

É claro que, ao ir se imbuindo do "espírito da língua", o aluno pode ampliar seus horizontes e inclusive aumentar sua capacidade de interpretação - o que não quer dizer que não tenha realmente entendido o texto só porque inicialmente se valeu da tradução.

Aí entra uma última questão: será que é possível atingir uma real fluência na leitura de um idioma apenas desenvolvendo essa habilidade? Infelizmente não sabemos responder a essa pergunta, mas parece que um certo grau é possível, principalmente quando a língua estudada não é tão distante da língua materna do aprendiz. Entretanto, para realmente conseguir entender determinados textos, que fogem às normas, por exemplo, é necessário ter um conhecimento bastante profundo da língua, que inclua também as outras habilidades e elementos culturais. Assim, é recomendável a alunos que querem realmente ler com fluência tentar desenvolver as outras habilidades e se envolver mais com a cultura do(s) país(es) em questão, o que pode acontecer através de cursos comunicativos, feitos paralelamente ou após o término do curso para leitura. Cursos para leitura, por darem ênfase aos textos, são recomendáveis também a alunos que já fazem cursos comunicativos e que querem se dedicar mais a textos, por necessidade ou prazer, principalmente se estão envolvidos com uma área específica do saber; nesse caso, provavelmente não terão a chance de ler textos de suas áreas em cursos de idiomas convencionais.

VAN PASSEL (1983: 54) acredita que a língua especializada geral não deve constituir um fim em si mesmo; deveria ser, na verdade, vista como complemento. O mesmo autor (1983: 55) ainda diz que é geralmente difícil constituir grupos homogêneos em se tratando de cursos do que ele chama de línguas especializadas; é, assim, recomendável que o aluno, antes de ter acesso ao vocabulário técnico, faça um curso elementar "que lhe dê prática nos quatro aspectos que caracterizam o uso da língua."

No nosso caso, pudemos constatar que há um grande número de interessados, dentro da universidade, por alemão para a leitura de textos de Filosofia e Ciências Sociais. Foi devido a essa procura, inclusive, que propusemos o curso. Entretanto, acreditamos que um curso para leitura como o nosso ${ }^{128}$ possa somente dar noções do idioma, e que o aluno deva,

\footnotetext{
127 “(...) se se admite que o leitor compreendeu o texto não é certamente porque ele conseguiu reter todas suas palavras. Deve-se, assim, distinguir da percepção verbal a apreensão do sentido, e postular que existe, no texto, uma série de dispositivos cuja função é favorecer o trabalho de apreensão do sentido, e de facilitar o esforço da percepção verbal, permitir 'reter parcialmente as palavras e integralmente o sentido' (Séleskovitch, 1975)." (tradução minha).

${ }^{128}$ Levando em conta o número de módulos, a carga horária, a distância entre o alemão e o português e o grau de dificuldade dos textos em questão.
} 
se quiser realmente se tornar fluente, continuar estudando sozinho, com as bases que lhe foram propiciadas, e fazer outros cursos - inclusive para desenvolver as outras habilidades, o que pode ser um fator importante no desenvolvimento da fluência em leitura. 


\title{
6. Considerações finais
}

De acordo com VIGNER (1979: 23):

\begin{abstract}
"Pouvoir lire, au fil des siècles, est devenu l'effort continu de l'homme pour échapper au cercle restreint du groupe auquel il appartient, pour accéder progressivement à une communauté intellectuelle et culturelle plus disperse, mais plus étendue, plus ouverte, disposant ainsi de nouvelles sources d'information (...). Lire permettra d'accéder au géneral, de passer de la coutume à la loi, du fait d'expérience à la théorie, à la règle, de parvernir à la fois à un degré supérieur de connaissance, d'abstraction et en même temps de conscience de soi." 129
\end{abstract}

Já SMITH (1989: 15) diz que:

"Não há nada de especial na leitura, a não ser tudo que nos possibilita fazer. O poder que a leitura proporciona é enorme, não somente por dar acesso a pessoas distantes e possivelmente mortas há muito, mas também por permitir o ingresso em mundos que, de outro modo, não seriam experimentados, que, de outro modo, não existiriam. A leitura permite-nos manipular o próprio tempo, envolvermo-nos em idéias ou acontecimentos em uma proporção e uma seqüência de nossa própria escolha. Não possuímos esse poder quando escutamos alguém falar, ou quando vemos um filme."

Lembramos ainda que "ler" vem da palavra latina "legere", que significa "colher"; segundo VIARO (2004: 157), recorreu-se ao velho mecanismo da metáfora para aproximar o ato de ler letras ao de escolher grãos de um cereal. E, ao ler, construímos significados, colhemos o que desejamos - mas só o que a plantação nos permite colher. E é papel do professor ajudar os alunos nessa colheita. ${ }^{130}$

Em suma, para o trabalho em um curso para leitura é necessário primeiramente que o professor conheça o grupo. Para isso, além de conversar com a classe, pode ser passado um questionário como o que aqui apresentamos. Cursos para leitura devem ser desenvolvidos no desenrolar das aulas: o professor prepara um plano inicial, que deve ser constantemente

\footnotetext{
129 "Poder ler, ao longo dos séculos, tornou-se o esforço contínuo do homem para fugir ao círculo restrito do grupo ao qual pertence, para ter acesso progressivamente a uma comunidade intelectual e cultural mais dispersa, mas mais extensa, mais aberta, que dispõe, assim, de novas fontes de informação (...). Ler deverá permitir ter acesso ao geral, passar do costume à lei, do fato de experiência à teoria, à regra, alcançar ao mesmo tempo um grau superior de conhecimento, de abstração e, simultaneamente, de consciência de si."

${ }^{130}$ Também em alemão a palavra "lesen", "ler", vem da agricultura e ainda pode significar, dentre outras coisas, "colher" e "escolher", conforme LEGROS (1997: 153).
} 
(re)elaborado de acordo com os objetivos, necessidades e dificuldades dos alunos. É até possível utilizar um material previamente elaborado que servirá como apoio.

Tendo em vista as características do grupo, parte-se para a escolha de textos. Devem ser considerados gênero e tipo textuais, os fatores de textualidade (a boa formação do texto), e deve-se proceder uma análise em termos morfológicos, sintáticos, lexicais e textuais. A partir daí e das necessidades e do nível dos alunos, o professor poderá depreender um ou mais aspectos para trabalhar tanto no âmbito lingüístico quanto no que diz respeito ao encadeamento textual e às estratégias que serão desenvolvidas. Mas primeiramente será buscado um tipo de compreensão que permitirá uma determinada leitura do texto. Após ter sido lido, o texto poderá servir como suporte para a língua.

Sendo assim, o trabalho pode ser dividido em fases: a fase pré-leitura, em que se tiram as impressões gerais do texto e se formulam hipóteses sobre seu conteúdo; a fase de leitura, em que o texto é lido com um determinado enfoque; e a fase pós-leitura, em que se faz algo com o que foi depreendido do texto. Além disso, há a fase de conscientização / fixação, na qual são trabalhados os fenômenos lingüísticos e textuais encontrados no texto, e que pode ser realizada antes ou após a fase pós-leitura. Em todas essas fases diversos exercícios podem ser feitos, bem como um trabalho com estratégias, buscando o desenvolvimento das diversas competências e a conscientização em relação aos estilos cognitivos.

É importante lembrar que os critérios organizatórios devem ser sempre considerados: número de alunos, número e frequiência das aulas, duração de cada aula, tempo de preparação do material e das aulas, tempo total do curso, possibilidades de trabalho em aula. Isso vai nortear a escolha de textos e o trabalho desenvolvido em classe. Também é fundamental que o professor tenha sempre objetivos claros e que analise como realizá-los da melhor forma possível levando em conta seus alunos e as questões de caráter organizacional do curso. Devese sempre considerar não só os objetivos das atividades, mas também o que os alunos devem realizar fora da aula. No caso de textos de uma área específica do saber, o professor, para montar seu curso, não deve restringir-se apenas aos alunos, mas tentar fazer uma pesquisa mais abrangente, perguntando a pessoas da área, a estudantes e analisando outros textos, além de inserir o que aqui chamamos de vocabulário técnico. Outro aspecto interessante é verificar a competência dos alunos na área específica, o que pode também ser útil, já que o conhecimento prévio pode facilitar a leitura. Além disso, é importante despertar a consciência dos alunos em relação ao que é texto, aos diferentes tipos existentes, aos diferentes tipos de compreensão e ao papel do leitor nesse processo. 
No que diz respeito ao ensino, é interessante, a nosso ver, tentar abordar em cada aula três aspectos diferentes: questões lingüísticas, ou seja, aspectos gramaticais, além de vocabulário relevante; estratégias que possam ajudar os alunos a compensar as falhas lingüísticas dos primeiros campos de redundância de que fala WESTHOFF (1987) e/ou a desenvolver sua consciência (meta)lingüística e aprender; e fenômenos textuais, com apoio na gramática frasal e do texto. Devido à falta de conhecimento lingüístico dos alunos, aconselhase trabalhar inicialmente com a compreensão global, para depois passar à compreensão de informações específicas e à compreensão detalhada. A apresentação deve ser feita majoritariamente em língua materna, já que o objetivo prioritário é a compreensão escrita. Entretanto, outras habilidades não precisam ser totalmente deixadas de lado. É sempre importante desenvolver um pouco as habilidades orais, ou melhor, uma competência oral mínima, mesmo que a ênfase seja dada na compreensão escrita, que é o caso. Isso é relevante porque tanto a forma gráfica quanto a fonológica permitem associações com elementos conhecidos, e esse é um dos pilares iniciais em que o aprendiz se apóia para entender os significados das palavras e para começar a construir o sentido do texto. Além disso, exercícios de produção podem ajudar na fixação e na memorização de vocábulos e estruturas.

Desse modo, é necessário que o professor, além de ter algumas das bases teóricas que procuramos apresentar aqui, esteja consciente de seu papel e de seus objetivos, pois só assim saberá escolher adequadamente os materiais e dar aos alunos a orientação adequada. Para isso, é preciso também que conheça esses alunos e que procure motivá-los com textos agradáveis, com tarefas interessantes, variadas e produtivas. É sempre importante, porém, que o professor tome cuidado com práticas que não indicam compreensão ou que não são apropriadas para os objetivos pré-estabelecidos. Deve-se ainda lembrar que os mesmos exercícios podem ser readaptados para tipos de leituras diferentes, e o mesmo resultado pode ser atingido de maneiras variadas; o professor deve saber adequar as tarefas a cada grupo e às suas necessidades específicas, buscando sempre o desenvolvimento dos alunos e a educação para a autonomia. A ação docente é um exercício contínuo de tomada de decisões, e também nesse sentido acreditamos que o professor, tendo boas bases em que se apoiar para escolher quais caminhos seguir, deve aprender a ser autônomo. E ele também pode ser uma peça-chave, à medida que pode despertar paixões ou ódio nos alunos, inclusive - e principalmente - em relação àquilo que leciona. Professores entusiasmados, que vêem seus alunos como pessoas e que são sensíveis a suas características, interesses e problemas estão no caminho certo - mas é necessário que haja, também, conhecimento daquilo que se ensina e uma boa visão do todo. $\mathrm{O}$ fato de aqui não estabelecermos modelos prontos e de os estudiosos terem dificuldade em 
descrever processos não quer dizer que o assunto seja necessariamente difícil de ser ensinado / aprendido. Cabe ao professor escolher com sabedoria e propriedade. Lembramos aqui que "escolher" significa "colher para fora" (ex-colher) e que também está ligado ao verbo latino "legere", que resultou em "ler". Leituras e escolhas são, assim, parte de um trabalho fascinante empreendido pelo professor para que os alunos também saibam escolher sozinhos seus caminhos e possam ampliar seus horizontes através da leitura. 


\section{Conclusão}

Buscamos apresentar aqui diretrizes teóricas e práticas para a preparação e execução de cursos para leitura, que devem ser devidamente adaptadas segundo o idioma e as especificidades do curso e do grupo com que se vai trabalhar. Para ilustrar, apresentamos exemplos retirados de uma experiência que tivemos com um curso de alemão para a leitura de textos de Filosofia e Ciências Sociais, realizado através do Centro de Línguas da Faculdade de Filosofia, Letras e Ciências Humanas da Universidade de São Paulo no ano letivo de 2006. Pelo fato de existirem poucos trabalhos na área de cursos voltados especificamente para a leitura em língua estrangeira, tanto no que diz respeito a concepções teóricas necessárias ao professor quanto a um suporte para a elaboração de tais cursos, acreditamos que nosso trabalho pode contribuir para o estabelecimento de algumas diretrizes e para a discussão de diversas questões relevantes.

Cursos para leitura são úteis porque atendem um público que tem como objetivo principal ler em língua estrangeira, e que não tem muito tempo ou vontade de se dedicar ao desenvolvimento das outras habilidades (compreensão oral, produção oral e produção escrita). No Brasil são mais procurados os cursos de inglês e de francês com esses fins, e também, talvez em menor escala, os de italiano e espanhol, devido à necessidade de leitura de textos nesses idiomas (por motivos profissionais e acadêmicos) ${ }^{131}$ e pelas semelhanças dos três últimos com o português (o que parece facilitar a decisão de fazer tais cursos e também sua continuidade). Esses cursos têm bastante procura e parecem ter um bom nível de sucesso.

Os cursos de alemão para leitura são menos procurados, e quem o faz muitas vezes se dedica a estudos de Filosofia e Ciências Sociais - e tem a necessidade de ler textos de autores alemães no original. Foi por essa razão que o nosso curso se voltou a tal público, embora um grande número de pessoas de outras áreas também se interesse por leitura de textos em alemão, como é o caso de estudantes e profissionais de Psicologia, Química, Direito, Engenharia e Letras.

Assim, da mesma forma que para os outros idiomas, acreditamos que um curso de alemão para leitura também pode ser válido e útil. Entretanto, no caso do nosso curso, devido à reduzida carga horária, às diferenças da língua alemã em relação ao português e ao grau de dificuldade dos textos das áreas em questão (em termos lingüísticos e de conteúdo, mesmo

\footnotetext{
${ }^{131}$ Inclusive para a aprovação em provas de proficiência, que é muitas vezes exigida para o ingresso em cursos de pós-graduação, mestrado e doutorado, e para a leitura de textos no idioma em questão durante tais cursos.
} 
para especialistas ou estudantes da área), não conseguimos passar das fases iniciais. Seria interessante propor um curso de maior duração para poder comparar os resultados e ver se é possível alcançar um grau de proficiência de leitura elevado em uma língua tão diferente da língua materna sem desenvolver as outras habilidades. ${ }^{132}$ Outro caminho interessante seria comparar a proficiência em leitura de alunos que desenvolvem as outras habilidades e aqueles que fazem apenas cursos para leitura. De qualquer forma, desenvolver as outras habilidades parece facilitar na memorização / aprendizagem de palavras novas e na "imersão" gradual no espírito da língua, o que poderia levar à fluência em leitura. No nosso caso, devido à carga horária reduzida, recomendamos aos alunos desde o início que fizessem outros cursos (como os comunicativos), paralela ou posteriormente ao nosso, se quisessem realmente se dedicar a autores de língua alemã e não apenas ter noções do idioma. E mesmo que o desenvolvimento das outras habilidades não se provasse tão necessário ou relevante caso houvesse mais tempo para os cursos para leitura, qualquer contato com a língua estudada é sempre útil, ou seja, quanto mais contato, melhor. Como pudemos constatar, saber palavras é importantíssimo, e o contato com a língua em outras situações pode levar à aprendizagem de palavras novas, que poderão ser úteis em outros contextos. E tal contato pode ser feito de forma otimizada com foco na aprendizagem em outros cursos, como os comunicativos.

Uma vantagem clara de cursos de alemão para leitura decorre justamente do formato dos cursos comunicativos. Como seu objetivo é desenvolver as quatro habilidades e costumase imaginar que os alunos vão viver nos países de língua alemã ou viajar para lá, dá-se ênfase a situações comunicativas reais e a textos cotidianos. $\mathrm{O}$ fato de o público ser geralmente heterogêneo também dificulta o trabalho com textos de áreas específicas. Em geral os livros didáticos trazem textos adaptados ou fabricados, e muitas vezes para apresentar pontos gramaticais. Como pudemos constatar por experiência, após quatro anos de alemão, ou seja, ao término do que é considerado o nível básico (Grundstufe), os alunos têm extrema dificuldade para a leitura, principalmente porque a língua é muito diferente do português ou de outras línguas estudadas ${ }^{133}$ - e nas aulas dos cursos mais encontrados se dá muita ênfase à comunicação, especialmente oral; atividades de leitura e escrita são comumente deixadas como tarefa de casa, que muitas vezes os alunos não fazem (e, mesmo quando o fazem, não se

\footnotetext{
${ }^{132}$ Como deve acontecer com grego clássico e latim, que também são cursos procurados, embora em menor escala do que os idiomas antes mencionados. No caso do grego e de outras línguas que se valem de outros alfabetos, pesquisas interessantes poderiam envolver a questão da "decodificação" das letras, que representa mais uma dificuldade para a leitura e que também deve ser levada em conta pelos professores que trabalham com línguas escritas com um alfabeto que não o latino (ou seja, que não o mesmo alfabeto utilizado na língua materna dos alunos) ou que tenham um sistema de escrita diferente.

${ }^{133}$ Principalmente em termos de vocabulário, a nosso ver, mas também devido a determinadas construções sintáticas.
} 
beneficiam do suporte que o professor poderia fornecer). Essa, aliás, parece ser uma prática generalizada não só no ensino de língua alemã. Mas voltando à questão, mesmo fazendo quatro anos de um curso comunicativo, um aluno que queira ler textos em alemão terá bastante dificuldade para fazê-lo. Por isso pode ser interessante que ele - principalmente se tiver a leitura como um objetivo importante, o que é o caso de vários estudantes de Filosofia, por exemplo - faça paralelamente um curso para leitura, pois assim já poderá começar a trabalhar com textos mais ligados à sua área ou a seus interesses desde o início do estudo do idioma, sem ter que esperar quatro anos (ou mais) para tanto.

Outra aplicação dos cursos para leitura pode ser em cursos de graduação de Letras em que os alunos não têm conhecimento da língua estrangeira de sua habilitação, iniciando "do zero". Fazer um curso para leitura paralelamente ao curso comunicativo poderia dar ao aluno uma visão geral mais rápida das estruturas da língua e facilitar a "aprendizagem comunicativa" (naturalmente mais lenta), à medida que o aluno já ganharia um conhecimento passivo das estruturas e de muitas palavras antes de ter de usá-las ativamente. Afinal, um curso para leitura pode ser mais curto do que outros, já que os alunos têm de "apenas" reconhecer estruturas e vocábulos escritos. Além disso, como os cursos de Letras também trazem disciplinas de Literatura, um curso para leitura nas fases iniciais poderia facilitar a leitura de textos no original nos anos seguintes. A mesma aplicação pode se dar em cursos de Letras com habilitação em Tradução: paralelamente ao curso comunicativo poder-se-ia estabelecer um curso para leitura, em que se trabalharia com textos de diversos tipos, podendo-se incluir ao final da leitura também a tradução (já que, nesse caso, ela é um objetivo dos alunos).

Em relação aos textos utilizados e à progressão didática, uma constatação que fizemos após nossa experiência é a de que é possível preparar um material prévio para ser utilizado em vários cursos, que deve ser complementado com textos sugeridos pelos alunos. Isso facilita o trabalho do professor e também ajuda na elaboração de uma sequiência mais coerente e bem pensada, o que pode ser mais adequado didaticamente.

Voltando à questão dos cursos para leitura propriamente ditos, uma outra constatação relevante que fizemos, ao trabalharmos com uma língua tão diferente da língua materna dos alunos, foi a importância do trabalho morfológico e da memorização de palavras. Em se tratando de línguas mais próximas (no sentido histórico, como o francês, e em termos de contato, como é o caso do inglês), parece que a memorização se dá de maneira mais fácil, talvez pela maior "familiaridade" das palavras e dos padrões silábicos. Além disso, em línguas em que há muitos cognatos, os alunos não precisam memorizar tanto, pois geralmente 
reconhecem as palavras quando elas aparecem, pela primeira vez ou não, como se daria, por exemplo, com a leitura de "elaboration" em inglês, "élaboration" em francês e "elaboración" em espanhol, mas não com a palavra alemã "Ausarbeitung”. Uma forma possível de descobrir o significado ou aproximar-se dele é analisar a palavra: "Arbeit" é "trabalho"; o prefixo / a preposição "aus-" significa "para fora". "Trabalhar para fora" é "e(x)-laborare". Embora os alunos em geral não saibam latim e grego nem se dêem conta dos elementos que formam as palavras em sua língua materna, mesmo quando são compostas de partes mais "transparentes" em termos "sincrônicos", a análise pode ser uma forma de memorizar a palavra (através de associações) após ter sido revelado seu significado. ${ }^{134} \mathrm{E}$, durante a leitura do texto, o desdobramento da palavra levaria o aluno à "Arbeit", que poderia lhe dar pistas do sentido do todo. E, principalmente em textos como os das áreas do nosso curso, há muitas palavras abstratas que são decalques de palavras do latim e do grego, e que preservamos em grande parte em português. Estabelecer uma comparação entre palavras latinas e gregas que foram decalcadas para o alemão e que temos em português poderia facilitar o ensino, pelo menos no que diz respeito ao reconhecimento de palavras, pois para a produção outros fatores entrariam em jogo (como usos específicos dessas palavras em cada idioma, expressões antiquadas ou utilizadas só em certos contextos em uma língua e não na outra, etc.).

Assim, acreditamos que cursos para leitura podem ser bem desenvolvidos e alcançar bons resultados se bem elaborados, e através deste trabalho e do relato da nossa experiência buscamos estabelecer diretrizes que possam orientar professores nesse sentido. Além disso, procuramos levantar algumas questões que podem auxiliar e conscientizar professores, principalmente de alemão, que estejam trabalhando com leitura. Acreditamos também que a partir do nosso trabalho seja possível traçar novos caminhos de pesquisa e de reflexão, que poderão contribuir tanto no âmbito teórico quanto no âmbito prático referente ao ensino / aprendizagem de línguas estrangeiras, mais especificamente no que aqui chamamos de cursos para leitura.

\footnotetext{
${ }^{134}$ Essa análise também ajuda no despertar da consciência lingüística e metalingüística do aluno, também em língua materna.
} 


\section{Referências bibliográficas}

AGATI, A. Abilità di lettura. Torino: Paravia, 1999.

ALMEIDA, R. L. M. Do francês instrumental a uma proposta de Língua Estrangeira para o primeiro grau. 1990. 238 f. Dissertação (Mestrado em Língua Francesa) - Faculdade de Filosofia, Letras e Ciências Humanas, Universidade de São Paulo, São Paulo, 1990.

ALMEIDA FILHO, J. C. P. de. Dimensões comunicativas no ensino de línguas. Campinas, SP: Pontes, 1993.

ALMEIDA FILHO, J. C. P. de. Lingüística Aplicada - Ensino de Línguas e Comunicação. Campinas, SP: Pontes Editores e Arte Língua, 2005.

AlmeidA FIlHO, J. C. P. de; CAVAlCANTI, M.; OliveiRA, P. S. X.; GiUlianO, M. S. M. A. Planejamento Piloto: Curso Básico de Leitura em Alemão para Fins Acadêmico-Científicos (exemplificado em curso para estudantes de Filosofia). Unicamp, 1989. Cópia do projeto.

ARNAUD, P. J. L.; SAVIGNON, S. J. "Rare words, complex lexical units and the advanced learner". In: COADY, J.; HUCKIN, T. (orgs.). Second Language Vocabulary Acquisition: a Rationale for Pedagogy. Cambridge: Cambridge University Press, 1997. p. 157-173.

AUPECLE, M; ALVAREZ, G. Français instrumental et français fonctionell. Strasbourg: ?, 1977.

BALBONI, P. E. Didattica dell’́Italiano a Stranieri. Roma: Bonacci, 1994.

BERRUTO, G. Sociolingüística dell’italiano contemporaneo. Roma: NIS, 1987.

BERTOCCHINI, P.; COSTANZO, E. Manuel d'autoformation. À l'usage des professeurs des langues. Paris: Hachette, 1989.

BESSE, H.; PORQUIER, R. Grammaire et didactique des langues. Paris: Hatier, 1984.

BIMMEL, P. "Wegweiser im Dschungel der Texte". In: Fremdsprache Deutsch - Arbeit mit Texten. April 1990. München: Klett, 1990.

BOHN, H. "Lingüística Aplicada”. In: BOHN, H. I.; VANDRESEN, P. (orgs.). Tópicos de Lingüística Aplicada: O Ensino de Línguas Estrangeiras. Florianópolis: Editora da UFSC, 1988a. p.11-39.

BOHN, H. "Avaliação de materiais". In: BOHN, H. I.; VANDRESEN, P. (orgs.). Tópicos de Lingüística Aplicada: O Ensino de Línguas Estrangeiras. Florianópolis: Editora da UFSC, 1988b. p.292-313. 
BORNEBUSCH, H.; FISCHER, E. “Alemão como língua instrumental para filósofos”. In: CORACINI, M. J. (org). Ensino Instrumental de Línguas. Argumentação, Análise do Discurso, Aspectos Pedagógicos da Leitura. Série Cadernos PUC-SP. São Paulo: EDUC, 1987. p.113-122.

BRANDI, M. L.; MOMENTEAU, B. Lesekurs für Geisteswissenschaftler. Fortgeschrittene. München: Klett, 1992.

BUGGENHAGEN, A. Alemão científico: primeiros passos. São Paulo: Herder, 1968.

BUHLMANN, R.; FEARNS, A. Handbuch des Fachsprachenunterrichts. Berlin / München: Langenscheidt, 1987.

CALAQUE, E. Lire et comprendre: l’itinéraire de lecture. Grenoble: CRDP de Grenoble, 1995.

CANDIDO, A. et al. O Francês Instrumental: a Experiência na Universidade de São Paulo. São Paulo: Hemus, 1977.

CARDOSO-SILVA, E. Prática de leitura: sentido e intertextualidade. São Paulo: Humanitas / FFLCH-USP, 2006.

CARRELL, P. L. "Role des Schémas de Contenu et des Schémas Formels". In: GAONAC'H, D. (org.) Acquisition et utilisation d'une langue étrangère. L'approche cognitive. Paris: Hachette, 1990. p.16-29.

CARVALHO, S. N. de. "O enfoque instrumental na leitura". In: SOLETRAS. Revista do Departamento de Letras da Faculdade de Formação de Professores da UERJ. Rio de Janeiro, 2005. p. 116-129. Disponível em http://www.Filologia.org.br/soletras/10/12.htm . Último acesso em 04.abr.2007.

CAVAlCANTI, M. C. Interação Leitor-Texto: Aspectos de Interpretação Pragmática. Campinas: Editora da Unicamp, 1989.

CHAGAS, V. Didática especial de línguas modernas. São Paulo: Companhia Editora Nacional, 1979.

CIAPUSCIO, G. "Tipos textuales”. Buenos Aires, Oficina de publicaciones del Ciclo Básico Común. Universidad de Buenos Aires, 1994. Texto apresentado pela Prof. Estela R. Klett no material utilizado em curso para monitores do Centro de Línguas da FFLCH-USP (Lectocomprensión en lengua extranjera. Cómo? Cuándo? Por qué?) realizado de 3 a 6 de abril de 2006.

CICUREL, F. Lectures interactives en langue étrangère. Paris: Hachette, 1991. 
COADY, J. "L2 vocabulary acquisition: a synthesis of the research". In: COADY, J.; HUCKIN, T. (orgs.) Second Language Vocabulary Acquisition: a Rationale for Pedagogy. Cambridge: Cambridge University Press, 1997. p. $273-290$.

COADY, J.; HUCKIN, T. (orgs.) Second Language Vocabulary Acquisition: a Rationale for Pedagogy. Cambridge: Cambridge University Press, 1997.

COIRIER, P.; GAONAC'H, D.; PASSERAULT, J. M. Psycholinguistique textuelle: une approche cognitive de la compréhension et de la production des textes. Paris: Armand Colin, 1996.

COLOMER, T.; CAMPS, A. Ensinar a ler, ensinar a compreender. Tradução de Fátima Murad. Porto Alegre: Artmed, 2002.

CONSEIL DE L’EUROPE. Cadre européen commun de référence pour les langues. Apprendre. Enseigner. Evaluer. Strasbourg, Conseil de 1’Europe, 1998. Versão em arquivo PDF, baixada do site http://www.coe.int/T/DG4/Portfolio/documents/cadrecommun.pdf em agosto de 2005.

CORACINI, M. J. R. F. O jogo discursivo na aula de leitura: língua materna e língua estrangeira. Campinas: Pontes, 1995.

COSTA, W. C. “Tradução e ensino de línguas”. In: BOHN, H. I; VANDRESEN, P. (orgs.) Tópicos de Lingüística Aplicada: O Ensino de Línguas Estrangeiras. Florianópolis: Editora da UFSC, 1988. p. 282-291

DABENE, L. Repères sociolinguistiques pour l'enseignement des langues. Paris: Hachette, 1994.

DABENE, M. (org.) L'évaluation de la lecture. Approches didactiques et enjeux sociaux. Grenoble: Presses Universitaires de Grenoble, 1994.

DABENE, M.; QUET, F. La compréhension des textes au collège. Lire, comprendre, interpréter des textes au collège. Grenoble: CRDP de l’Académie de Grenoble et Delagrave, 1999.

DAM, L. "Developing awareness of learning in an autonomous language learning context". In: DUDA, R.; RILEY, P. (orgs). Learning Styles. Nancy: Presses Universitaires de Nancy, 1990. p.189-197.

DARDANO, M. Il linguaggio dei giornali italiani. Roma: Laterza, 1981.

DARSKI, J. “Welche Grammatik braucht der Lerner?”. In: DITTMAR, N.; ROST-ROTH, M. (Hrsg.) Deutsch als Zweit- und Fremdsprache: Methoden und Perspektiven einer akademischen Disziplin. Frankfurt: Peter Lang, 1995. 
DICKINSON, L. Self-instruction in Language Learning. Cambridge: Cambridge University Press, 1987.

DITTMAR, N. "Was lernt der Lerner und warum? Was DaF-Lehrer schon immer über den Zweitspracherwerb wissen wollten”. In: DITTMAR, N.; ROST-ROTH, M. (Hrsg.) Deutsch als Zweit- und Fremdsprache: Methoden und Perspektiven einer akademischen Disziplin. Frankfurt: Peter Lang, 1995.

DORRONZORO, M. I.; PASQUALE, R. "Fichas teóricas para las asignaturas de lectocomprensión en lenguas extranjeras". Universidad Nacional de Lujan, 1999. Texto apresentado pela Prof. Estela R. Klett no material utilizado em curso para monitores do Centro de Línguas da FFLCH-USP (Lectocomprensión en lengua extranjera. Cómo? Cuándo? Por qué?) realizado de 3 a 6 de abril de 2006.

DUDA, R.; RILEY, P. (orgs). Learning Styles. Nancy: Presses Universitaires de Nancy, 1990.

ELLIS, G.; SINCLAIR, B. "Helping learners discover their learning styles". In: DUDA, R.; RILEY, P. (orgs). Learning Styles. Nancy: Presses Universitaires de Nancy, 1990. p.167-174.

ELLIS, R. Understanding Second Language Acquisition. Oxford, Oxford University Press, 1985.

FÁVERO, L. L. Coesão e coerência textuais. São Paulo: Ática, 1997.

FERREIRA, A. S. Interações em um curso de inglês instrumental mediado pelo computador: expectativas e resultados. 1998. 169 f. Dissertação (Mestrado em Língua Inglesa) - Pontifícia Universidade Católica, São Paulo, 1998.

FERRERI, S. “Andar per gradi nei testi”. In: Italiano Oltre, n 4. Firenze: Nuova Itália, 1989. p. 153-154.

FOUCAMBERT, J. A leitura em questão. Tradução de Bruno Charles Magne. Porto Alegre: Artes Médicas, 1994.

FRIER, C.; GROSSMANN, F. "Lecture et construction du sens: évaluation de la compréhension de textes specialisés par des étudiants de prémière année de DEUG”. In: DABENE, M. (org.) L'évaluation de la lecture. Approches didactiques et enjeux sociaux. Grenoble: Presses Universitaires de Grenoble, 1994. p.149-178.

FUHR, G. Gramática do Alemão Científico (Bausteine: Fachdeutsch für Wissenschaftler). São Paulo: EPU, 1989.

FULGÊNCIO, L.; LIBERATO, Y. Como facilitar a leitura. São Paulo: Contexto, 1996.

GAONAC'H, D. “Les stratégies attentionelles dans l'utilisation d'une langue étrangère”. In: GAONAC'H, D. (org.) Acquisition et utilisation d'une langue étrangère. L'approche cognitive. Paris: Hachette, 1990. 
GAONAC'H, D. (org.) Acquisition et utilisation d'une langue étrangère. L'approche cognitive. Paris: Hachette, 1990.

GAllisOn, R.; COSTE, D. Dicionário de Didáctica das Línguas. Tradução de Adelina Angélica Pinto et al. Lisboa: Almedina, 1983.

GARCIA, L. A. M. Competências e habilidades: você sabe lidar com isso? Universidade de Brasília. Disponível em http://www.escola2000.org.br/pesquise/texto/textos_art.aspx?id=36. Último acesso em 04 abr. 2007.

GÄRTNER, A. Lesekurs Deutsch im Bereich der Geisteswissenschaften für Studierende an brasilianischen Universitäten. Porto Alegre: ?, 1977.

GERMAIN, C.; SEGUIN, H. Le point sur la grammaire. Paris: Clé International, 1998.

GIASSON, J. La compréhension en lecture. Bruxelas: gaëtan morin, 1990.

GRABE, W.; STOLLER, F. L. "Reading and vocabulary developing in a second language: a case study". In: COADY, J.; HUCKIN, T. (orgs.) Second Language Vocabulary Acquisition: a Rationale for Pedagogy. Cambridge: Cambridge University Press, 1997. p. 98 -122.

HAMM, C.; FUHR, G. Bausteine - Fachdeutsch für Wissenschaftler: Philosophie. São Paulo: EPU, 1989.

HARDJONO, T. "Von der Jakarta-Messe zum Oktoberfest”. In: Fremdsprache Deutsch - Arbeit mit Texten. April 1990. München: Klett, 1990.

HÄUSSERMANN, U.; PIEPHO, H. E. Aufgaben-Handbuch. Deutsch als Fremdprache. Abriss einer Aufgaben und Übungstypologie. München: Iudicium, 1996.

HERINGER, H. J. Wege zum verstehenden Lesen. Lesegrammatik für Deutsch als Fremdsprache. München: Hueber, 1987.

JOVANOVIC, V. A. "Ensino de línguas e o papel da gramática”. In: Revista da Faculdade de Educação, 12 (1/2). São Paulo: FEUSP, jan/dez 1986. p.145-156

JOVANOVIC, V. A. "Língua materna vs. língua estrangeira: uma relação fundamental (porém menosprezada) no ensino/aprendizagem de línguas". In: Revista da Faculdade de Educação, 18 (2). São Paulo: FEUSP, julho/dez 1992. p.174-184.

KLEIMAN, A. Leitura: Ensino e Pesquisa. São Paulo: Pontes, 1989. 
KOCH, I. Introdução à Lingüística Textual. São Paulo: Martins Fontes, 2004.

KOCH, I. O texto e a construção dos sentidos. São Paulo: Contexto, 2001.

KOHONEN, V. “Towards Experiential Learning in Elementary Foreign Language Education”. In: DUDA, R.; RILEY, P. (orgs). Learning Styles. Nancy: Presses Universitaires de Nancy, 1990.

LARANJEIRA, M.; LAUNAY, M. “O Francês Instrumental na Universidade de São Paulo”. In: CANDIDO, A. et al. O Francês Instrumental: a Experiência na Universidade de São Paulo. São Paulo: Hemus, 1977.

LAUFER, B. "The lexical plight in second language reading". COADY, J.; HUCKIN, T. (orgs.) Second Language Vocabulary Acquisition: a Rationale for Pedagogy. Cambridge: Cambridge University Press, 1997. p. 20-34.

LAVEAU, I. Sach- und Fachtexte im Unterricht Deutsch als Fremdsprache. München: GI, 1985.

LEFFA, V. J. "Metodologia do Ensino de Línguas". In: BOHN, H. I.; VANDRESEN, P. (org). Tópicos de Lingüística Aplicada: o Ensino de Línguas Estrangeiras. Florianópolis: Editora da UFSC, 1988. p.211-236.

LEFFA, V. J. Aspectos da leitura. Uma perspectiva psicolingüística. Porto Alegre: DC Luzzatto, $1996 \mathrm{a}$.

LEFFA, V. J. "Fatores da compreensão na leitura”. In: Cadernos do IL. Porto Alegre, v.15, n.15, 1996b. p.143159.

LEFFA, V. J. "Perspectivas no estudo da leitura: texto, leitor e interação social”. In: LEFFA, V. J.; PEREIRA, A. E. (orgs.) O ensino da leitura e produção textual: alternativas de renovação. Pelotas: Educat, 1999. p. 1337.

LEGROS, W. Was die Wörter erzählen: Eine kleine etymologische Fundgrube. München: Deutscher Taschenbuch Verlag, 1997.

LERAT, P. Les langues spécialisées. Paris: Presses Universitaires de France, 1995.

LITTLE, D.; SINGLETON, D. “Cognitive style and learning approach”. In: DUDA, R.; RILEY, P. (orgs.) Learning Styles. Nancy: Presses Universitaires de Nancy, 1990.

LITTLEWOOD, W. Communicative Language Teaching: An Introduction. New York/Port Chester/ Melbourne/Sidney: Cambridge, 1981. 
LUNEAU, O. Eléments pour une introduction au français instrumental. Programa de pós-graduação em Letras e Lingüística - Departamento de Letras. Centro de Artes e Comunicação. Recife, 1978.

MEURER, J. L. "Compreensão de linguagem escrita: aspectos do papel do leitor". In: BOHN, H. I.; VANDRESEN, P. (orgs.) Tópicos de Lingüística Aplicada: O Ensino de Línguas Estrangeiras. Florianópolis: Editora da UFSC, 1988. p. 258-269.

MINARDI, G. "La lettura L1-L2”. In: Scuola e Lingue Moderne. ?: Garzanti Scuola, 2000.

MOIRAND, S. Une grammaire des textes et des dialogues. Paris: Hachette, 1990.

MONTEIRO, M. "Fachsprachen im DaF-Unterricht". DITTMAR, N; ROST-ROTH, M. (Hrsg.) Deutsch als Zweit- und Fremdsprache: Methoden und Perspektiven einer akademischen Disziplin. Frankfurt: Peter Lang, 1995. p. 303-316.

MONTEIRO, S. L. Francês Instrumental: uma proposta de abordagem do texto. 1994. 515 p. Dissertação (Doutorado em Língua Francesa) - Faculdade de Filosofia, Letras e Ciências Humanas, Universidade de São Paulo, 1994.

MUNHOZ, R. Inglês instrumental: estratégias de leitura. Módulo II. São Paulo: Textonovo, 2001.

NAGY, C. "Pour un enseignement de la grammaire fondé sur la compétence de 1'apprenant". In: BOURGUIGNON, C; FORESTER, C. (eds). La grammaire ça sert à quoi? Grenoble: Presses Universitaires de Grenoble, 1993.

NEUNER, G. "Texte auf dem Prüfstand”. In: Fremdsprache Deutsch - Arbeit mit Texten. April 1990. München: Klett, 1990.

NUNES, M. B. C. “O professor de EAP: comportamentos fossilizados ou vivência reflexiva?” In: DOLZ, J.; SCHNEUWLY, B. Gêneros orais e escritos na escola. Campinas: Mercado de Letras: 2004.

O’MALLEY, J. M.; CHAMOT, A. U. Learning Strategies in Second Language Acquisition. Cambridge/New York/Port Chester/Melbourne/Sidney: Cambridge, 1990.

OXFORD, R. Language Learning Strategies: What Every Teacher Should Know. Boston: Heinle \& Heinle, 1990.

PARIBAKHT, T. S.; WESCHE, M. "Vocabulary enhancement activities and reading for meaning in second language vocabulary acquisition”. In: COADY, J.; HUCKIN, T. (orgs.) Second Language Vocabulary Acquisition: a Rationale for Pedagogy. Cambridge: Cambridge University Press, 1997. p. 174 - 197. 
PARRY, K. "Vocabulary and comprehension: two portraits". In: COADY, J.; HUCKIN, T. (orgs.) Second Language Vocabulary Acquisition: a Rationale for Pedagogy. Cambridge: Cambridge University Press, 1997. p. 55-68.

PIEPHO, H. E. "Leseimpuls und Textaufgabe”. In: Fremdsprache Deutsch - Arbeit mit Texten. April 1990. München: Klett, 1990.

PIETRARÓIA, C. M. C. Percursos de Leitura: Léxico e Construção do Sentido na Leitura em Língua Estrangeira. São Paulo: Annablume, 1997.

PIETRARÓIA, C. M. C. Questões de leitura: aspectos práticos e teóricos da leitura em francês língua estrangeira. São Paulo: Annablume, 2001.

POSSENTI, S. Por que (não) ensinar gramática na escola? Campinas: Mercado de Letras - Associação de Leitura do Brasil, 1996.

RAMOS, V.; CARONI, I.; LAUNAY, M. et al. "Pressupostos Teóricos do Método". In: CANDIDO, A. et al. O Francês Instrumental: a Experiência na Universidade de São Paulo. São Paulo: Hemus, 1977. p. 37-41.

REIS, M. A. T. Le français instrumental à l'Université de São Paulo. Reflexions à partir d'une expérience personelle. 1979. 171 f. Dissertação (Mestrado em Língua Francesa). Faculdade de Filosofia, Letras e Ciências Humanas, Universidade de São Paulo, São Paulo, 1979.

REIS, M. A. T. Atividades e estratégias desenvolvidas por universitários para aprender a falar Francês um estudo de relatos verbais. 1990. 271 f. Tese (Doutorado em Língua Francesa). Faculdade de Filosofia, Letras e Ciências Humanas, Universidade de São Paulo, São Paulo, 1990.

REIS, M. A importância da competência gramatical no ensino comunicativo (em Língua Inglesa). São Paulo: Oficina de Textos, 1998.

RIVERS, W. M. A metodologia do ensino de línguas estrangeiras. Tradução de Hermínia S. Marchi. São Paulo: Pioneira, 1975.

ROULET, E. Teorias lingüísticas, gramáticas e ensino de línguas. São Paulo, Pioneira: 1972.

SÁNCHEZ PÉREZ, A. Hacia un método integral en la enseñanza de idiomas. Estudio analítico. Madrid: Sociedad General Española de Librería, 1993.

SCHRÖDER, H. Aspekte einer Didaktik / Methodik des fachbezogenen Fremdsprachenunterrichts (Deutsch als Fremdsprache). Frankfurt am Main: Peter Lang, 1988. 
SCLIAR-CABRAL, L. "Semelhanças e diferenças entre a aquisição das primeiras línguas e a aprendizagem sistemática das segundas línguas". In: BOHN, H. I.; VANDRESEN, P. (orgs.). Tópicos de Lingüística Aplicada: O Ensino de Línguas Estrangeiras. Florianópolis: Editora da UFSC, 1988. p.40-49.

SILVA, C. E. da. O processo de compreensão na leitura em língua estrangeira: relato de uma experiência com alunos de $2^{\mathbf{o}}$ grau. São Paulo: Humanitas/FFLCH/ USP, 2001.

SILVA, C. E. da. "A natureza e a função do input na interação em sala de aula de língua estrangeira". In: MELO, L. E. (org). Tópicos de Psicolingüística Aplicada. São Paulo: Humanitas, 2005a. p.121-132.

SILVA, C. E. da. "Compreensão e produção em língua estrangeira: da teoria à prática em sala de aula". In: MELO, L. E. (org). Tópicos de Psicolingüística Aplicada. São Paulo: Humanitas, 2005b. p.133-145.

SLAMA-CAZACU, T. Psicolingüística aplicada ao ensino de línguas. Tradução de Leonor Scliar Cabral. São Paulo: Pioneira, 1979.

SMITH, F. Compreendendo a leitura: uma análise psicolingüística da leitura e do aprender a ler. Tradução de Daise Batista. Porto Alegre: Artmed, 1989.

SOLÉ, I. Estratégias de leitura. Porto Alegre: ArtMed, 1998.

SOULE-SUSBIELLES, N. "L'apprenant apprend a se connaître". In: DUDA, R.; RILEY, P. (orgs). Learning Styles. Nancy: Presses Universitaires de Nancy, 1990. p.175-187.

TAGLIEBER, L. K. "A leitura na língua estrangeira”. In: BOHN, H. I.; VANDRESEN, P. (orgs.) Tópicos de Linguística Aplicada: O Ensino de Línguas Estrangeiras. Florianópolis: Editora da UFSC, 1988. p.237-257.

TURCOTTE, A. G. "Compétences et perceptions du lecteur évaluées de façon authentique". In: DABENE, M. (org.) L'évaluation de la lecture. Approches didactiques et enjeux sociaux. Grenoble: Presses Universitaires de Grenoble, 1994. p.13-38.

VAN DIJK, T. A. Cognição, discurso e interação. Org. Ingedore Koch. São Paulo: Contexto, 2000.

VAN DIJK, T. A. Textwissenschaft. Eine interdisziplinäre Einführung. Tradução de Christoph Sauer. Tübingen: Max Niemeyer, 1980.

VAN PASSEL, F. Ensino de Línguas para Adultos. Tradução de Hermínia S. Marchi. São Paulo: Pioneira/ Editora da USP, 1983.

VIARO, M. E. Por trás das palavras: manual de etimologia do português. São Paulo: Globo, 2004. 
VIGNER, G. Lire: du sens au texte. Paris: Clé International, 1979.

WESTHOFF, G. Didaktik des Leseverstehens. München: Hueber, 1987.

WESTHOFF, G. Fertigkeit Lesen. Fernstudienprojekt zur Fort- und Weiterbildung im Bereich Germanistik und Deutsch als Fremdsprache. München: Goethe-Institut / Langenscheidt, 1997.

ZIMMERMANN, C. B. "Historical trends in second language vocabulary instruction". In: COADY, J.; HUCKIN, T. (org.). Second Language Vocabulary Acquisition: a Rationale for Pedagogy. Cambridge: Cambridge University Press, 1997. p. 5-19. 